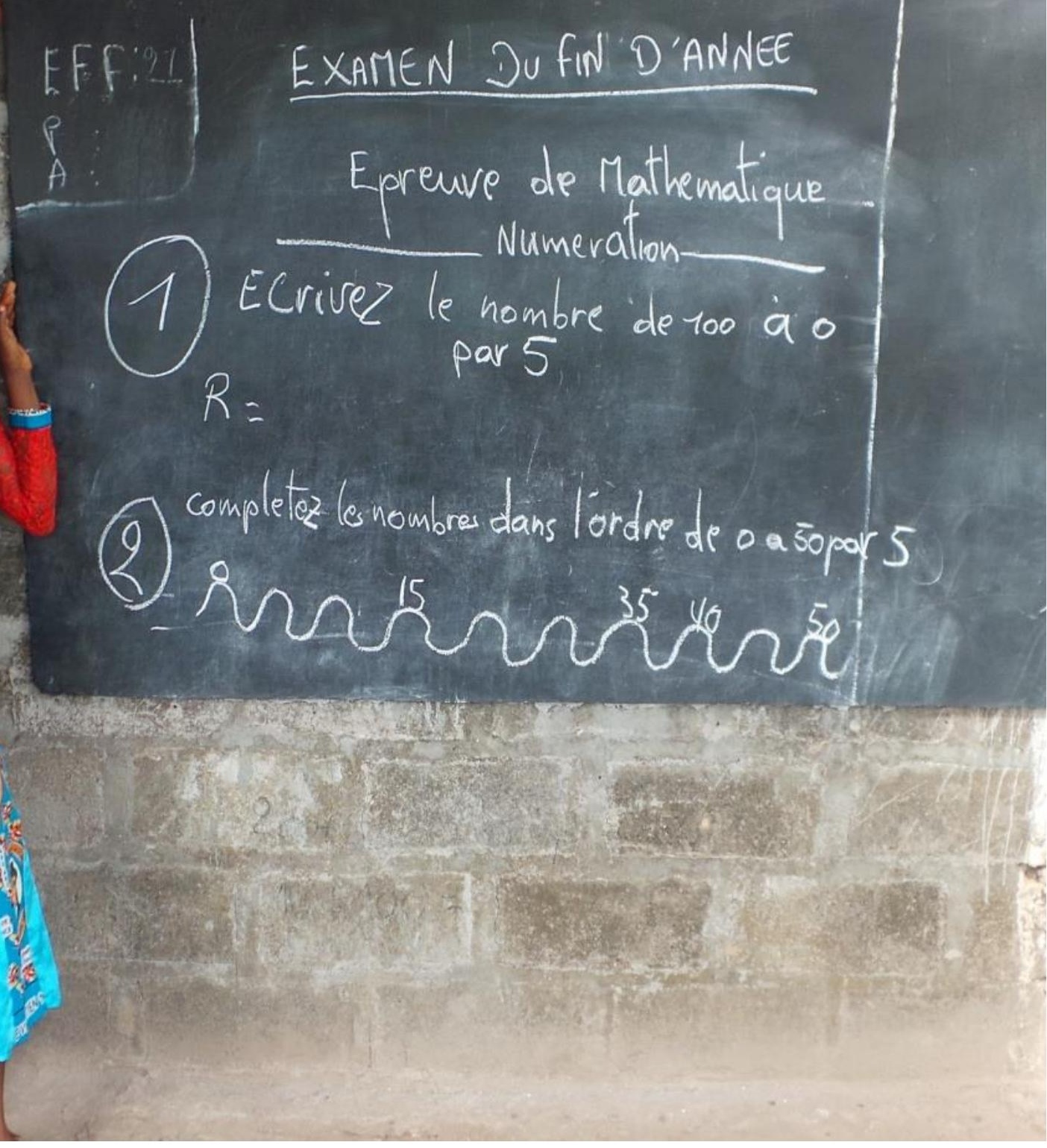

\title{
PUBLIC GOOD OR PRIVATE WEALTH?
}

Universal health, education and other public services reduce the gap between rich and poor, and between women and men. Fairer taxation of the wealthiest can help pay for them. 
Our economy is broken, with hundreds of millions of people living in extreme poverty while huge rewards go to those at the very top.

The number of billionaires has doubled since the financial crisis and their fortunes grow by $\$ 2.5 \mathrm{bn}$ a day, yet the super-rich and corporations are paying lower rates of tax than they have in decades. The human costs - children without teachers, clinics without medicines are huge. Piecemeal private services punish poor people and privilege elites. Women suffer the most, and are left to fill the gaps in public services with many hours of unpaid care.

We need to transform our economies to deliver universal health, education and other public services. To make this possible, the richest people and corporations should pay their fair share of tax. This will drive a dramatic reduction in the gap between rich and poor and between women and men.

This paper was written by Max Lawson, Man-Kwun Chan, Francesca Rhodes, Anam Parvez Butt, Anna Marriott, Ellen Ehmke, Didier Jacobs, Julie Seghers, Jaime Atienza and Rebecca Gowland. Oxfam acknowledges the assistance of Elizabeth Njambi, Charlotte Becker, Anna Ratcliff, Jon Slater, Ana Arendar, Patricia Espinoza Revollo, Irene Guijt, Franziska Mager, Iñigo Macías Aymar, Kira Boe, Katie Malouf Bous, Katharina Down, Nabil Ahmed, Matthew Spencer, Oliver Pearce and Susana Ruiz in its production. The authors are grateful to a range of experts who generously gave their assistance: Arjun Jayadev, Liepollo Lebohang Pheko, Deborah Hardoon, Gabriel Zucman, Debbie Budlender, Kate Pickett, Stephen Kidd, Patrick Asuming, Matthew Martin, Jonathan Ostry, Karin Stenberg and Danny Dorling. The paper is part of a series of papers written to inform public debate on development and humanitarian policy issues.

For further information on the issues raised in this paper please email advocacy@oxfaminternational.org

This publication is copyright but the text may be used free of charge for the purposes of advocacy, campaigning, education, and research, provided that the source is acknowledged in full. The copyright holder requests that all such use be registered with them for impact assessment purposes. For copying in any other circumstances, or for re-use in other publications, or for translation or adaptation, permission must be secured and a fee may be charged. Email policyandpractice@oxfam.org.uk.

The information in this publication is correct at the time of going to press. Published by Oxfam GB for Oxfam International under

ISBN 978-1-78748-365-1 in January 2019

DOI: $10.21201 / 2019.3651$

Oxfam GB, Oxfam House, John Smith Drive, Cowley, Oxford, OX4 2JY, UK.

Cover photo: Judith teaches at a school in Equateur province, Democratic Republic of the Congo. The school director died of the Ebola virus and Judith was quarantined for 21 days as a precaution. At the end of her isolation period, Oxfam helped her to reintegrate into her community. Oxfam has also supported the school with handwashing facilities, health promotion to dispel misinformation, and a rest area for students and staff who feel unwell. Photo: Alain Nking/Oxfam.

We'd like to learn more about our readers. Please tell how us how you're using this report by taking this short survey: http://bit.ly/InequalitySurvey 


\section{TABLE OF CONTENTS}

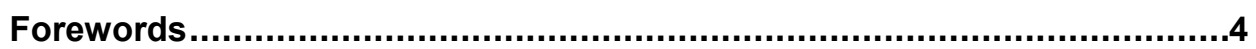

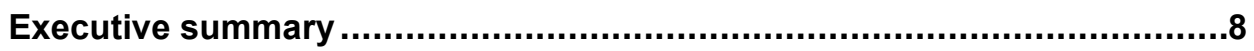

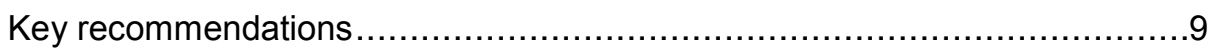

Public good, not private wealth ..................................................... 10

The divide that threatens to tear us apart............................................ 14

The power of public services to fight inequality .................................... 17

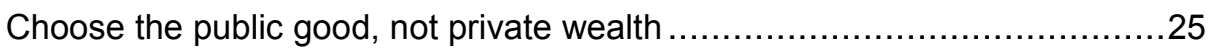

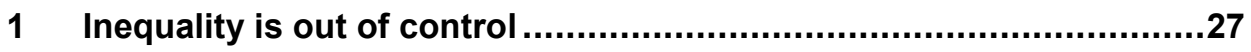

Our leaders are failing to tackle the growing gap between rich and poor $\ldots . . .27$

Another bumper year for billionaires.................................................28

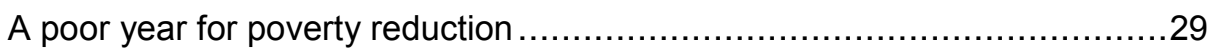

Why does the gap between rich and poor matter? .................................. 32

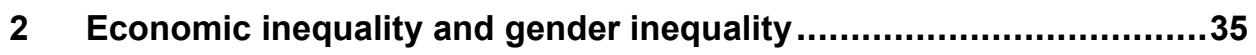

Economic policies and their impact on women and men ...........................36

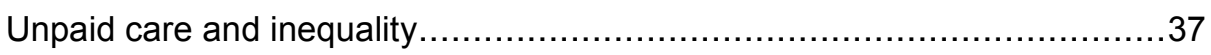

3 How public services and social protection can fight inequality .........41

Delivering an everyday miracle........................................................4 41

Progress, but patchy and unequal..................................................4 43

Poor-quality public services drive inequality in many countries ..................44

How can public services and social protection reduce inequality? ..............46

What kind of public services and social protection maximize the reduction in

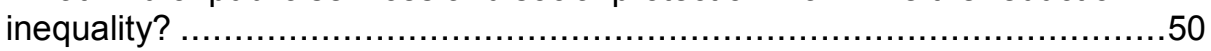

4 Paying for universal public services and social protection ..............60

Rich people and corporations must pay their fair share of tax...................61

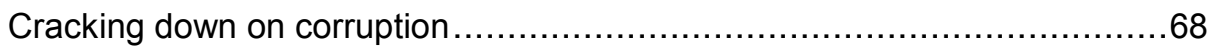

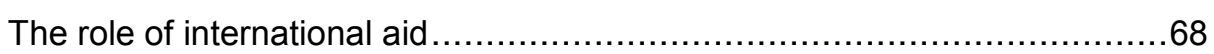

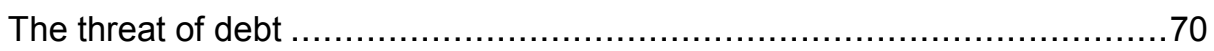

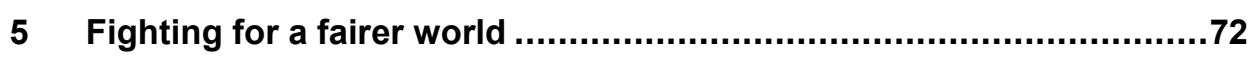

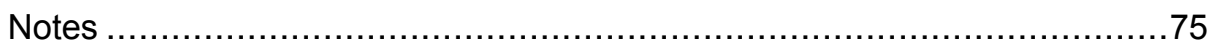




\section{FOREWORDS}

\section{Nellie Kumambala, secondary school teacher, Lumbadzi, Malawi}

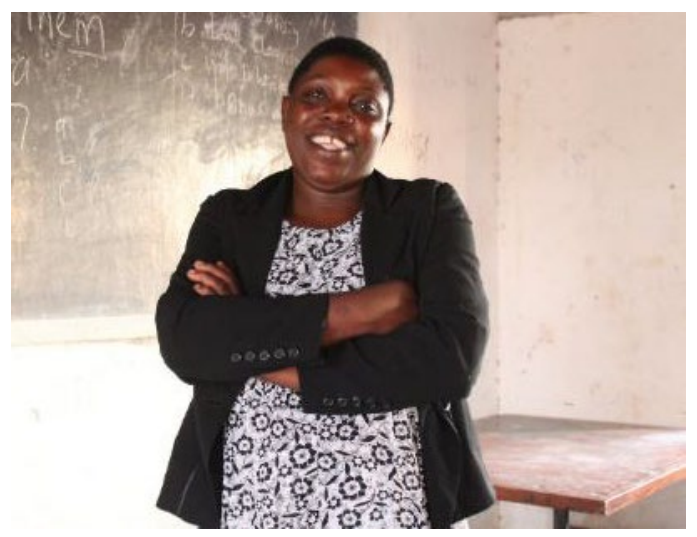

I have always wanted to be a teacher. My father, who passed away in 2015 , was a mathematics teacher all his life. He was the one who gave me the inspiration and wish to be a teacher. I have now been teaching for 19 years. My sisters are also teaching. We are a family of teachers!

I teach at the local community secondary school for my area. Children in my school come from very poor families. Many walk a long distance as there is not a nearby school. Many come to school with an empty stomach, which is a challenge to learning. In our school, we have a problem of too few textbooks, dilapidated classroom blocks and teaching materials. We have been sharing.

Over these years, I have seen so many clever girls and boys who score highly despite coming from poor backgrounds. I remember Chimwemwe Gabisa - she was brilliant at mathematics, the best I have taught. She finished secondary school but could not proceed to college for lack of funds.

I have seen the expensive private schools in the city, where the children of rich families can go - they have very good facilities. It does not seem right to me that it is so much harder for children in a government school to be educated. There is so little assistance to help them with their education.

This report from Oxfam has shown me just how big the gap between the rich and the poor is in this world. How very few people have so much, while so many have so little. How can God allow such a thing? I pay tax every month on my little salary that I get. I don't understand why the people that have everything are failing to pay their taxes, to help fund development.

With more money, a lot could be done at our school. We could provide students with breakfast. We could provide every student with textbooks. We could support them with the basic necessities like buying them school uniforms and other things like exercise books. At least this would give them a better chance in life. It would be wonderful if we were able to do this. 


\section{Nick Hanauer, entrepreneur and venture capitalist}

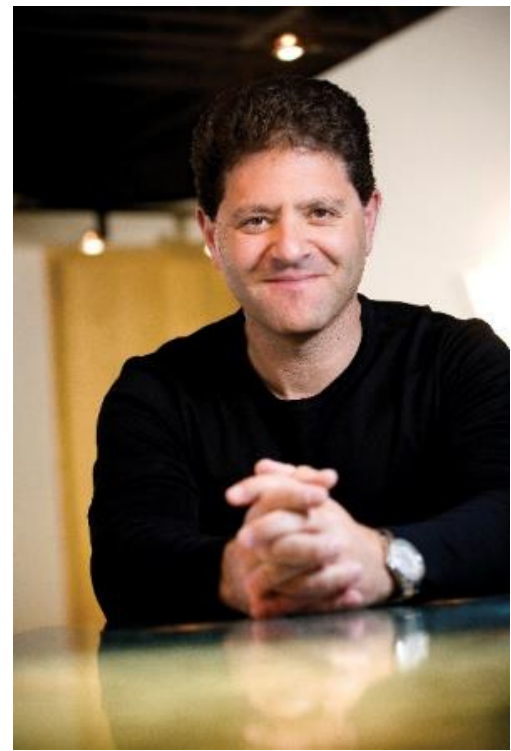

I am a practitioner of capitalism. I have started or funded 37 companies and was the first outside investor in Amazon. The most important lesson I have learned from these decades of experience with market capitalism is that morality and justice are the fundamental prerequisites for prosperity and economic growth. Greed is not good.

The problem is that almost every authority figure - from economists to politicians to the media - tells us otherwise. Our current crisis of inequality is the direct result of this moral failure. This exclusive, highly unequal society based on extreme wealth for the few may seem sturdy and inevitable right now, but eventually it will collapse. Eventually the pitchforks will come out, and the ensuing chaos will not benefit anyone - not wealthy people like me, and not the poorest people who have already been left behind.

To avert this existential crisis, we must drive a stake through the heart of the neoliberal religion that instantly rewards greed at the expense of our future. We must replace it with a new economic framework - what Oxfam has called a more 'Human Economy', which recognizes that justice and inclusion are not the result of economic prosperity, but rather the cause of economic prosperity.

Only a society that seeks to include all its people in the economy can succeed in the long term. To build such a society, the wealthiest should pay their fair share of tax - and as this year's Oxfam report demonstrates, right now they are doing the opposite. Top rates of tax on the wealthiest people and corporations are lower than they have been for decades. Unprecedented levels of tax avoidance and evasion ensure that the super-rich pay even less.

There can be no moral justification for this behaviour beyond the discredited neoliberal dogma that if everyone maximizes their selfishness, the world will somehow be a better place. It has no economic justification, either. In fact, it is economically self-defeating, as the ordinary people who drive a prosperous economy are instead impoverished in favour of the bank accounts of billionaires. I have absolutely no doubt in my mind that the richest in our society can and should pay a lot more tax to help build a more equal society and prosperous economy.

If our governments could tax wealth fairly, as the Oxfam report shows, we could ensure that every child gets a chance at a future. We could ensure that no person lives in fear of getting sick because they cannot afford their medical bills - whether in India or in my own nation, the 
United States. We could - and we should - use this wealth to build better, more equal economies and societies.

Today's neoliberal orthodoxy teaches us that inclusion and justice are luxuries. That health and education should be left to the mercy of the free market, available only to those who have the money to pay for them. That ever-lower taxation on the richest will only benefit economic growth. But this view is wrong and backward.

Ultimately it is our humanity, not the absence of it, that is the true source of economic growth and a flourishing civilization. This is not just an imperative for activists and academics but for all of us - including every billionaire. It is not a question of whether we can afford to do this. Rather, we cannot afford not to.

\section{Gro Harlem Brundtland, founding member of The Elders, Director-General of the World Health Organization 1998-2003, and first female Prime Minister of Norway}

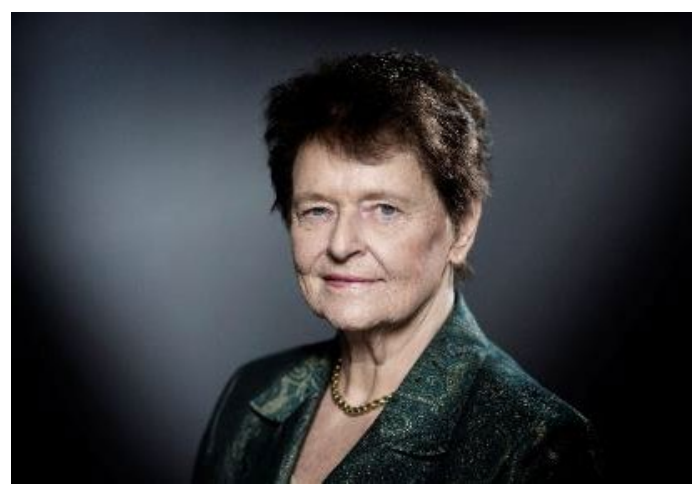

As Oxfam has been highlighting over the past five years, the level of economic inequality we are witnessing today is nothing short of a calamity. According to Oxfam's analysis, last year 26 people owned the same wealth as the 3.8 billion people who make up the poorest half of humanity, down from 43 people the year before. Although we have seen a growing political consensus to tackle extreme inequality, including a specific sustainable development goal on this issue, it is high time that we saw real action.

Oxfam's excellent report, Public Good or Private Wealth? recommends a practical way all countries can reduce inequality: by providing universal free public services. It focuses on the unparalleled power that public services, like education and health, play in tackling poverty, reducing inequality and fighting gender injustice. From my experience as Prime Minster of Norway and the Director-General of the World Health Organization, I thoroughly support this message.

In many countries, while those with money are able to access good healthcare and education, hundreds of millions of ordinary people are denied life-saving health services or are plunged into poverty because they are forced to pay unaffordable fees for their care. The burden is particularly felt by women and children, who have high needs for services but the least access to financial resources. In some countries, poor women and their babies are even imprisoned in hospitals because they can't pay their medical bills after giving birth. 
The solution to this problem is simple: universal public services provided free at the point of delivery. Unfortunately, powerful political interests often oppose this proven way to reduce inequalities.

Overcoming this opposition and launching equitable public services requires a large investment of public financing and political capital by governments and political leaders. As well as improving social indicators, accelerating economic growth and reducing inequalities, this is also a smart political choice that can strengthen social cohesion and provide an enduring legacy.

The first article of the Universal Declaration of Human Rights states that: 'All human beings are born free and equal in dignity and rights'. Seven decades on from the adoption of that landmark text, this Oxfam report is a powerful reminder of this principle, but also of the huge challenge that remains in turning these fine words into reality.

Fighting inequality remains one of the world's most testing issues.

Delivering universal public services is a tried and tested way to tackle it. We must now take action against extreme inequality to achieve a fairer, healthier and happier future for all, not just the few. 


\section{EXECUTIVE SUMMARY}

\section{PUDLC COOD OR PRIVATE WEALTH?}

THE WEALTH OF THE WORLD'S

BILLIONAIRES INCREASED

\$900 BILLION IN THE LAST YEAR,

WHICH IS:

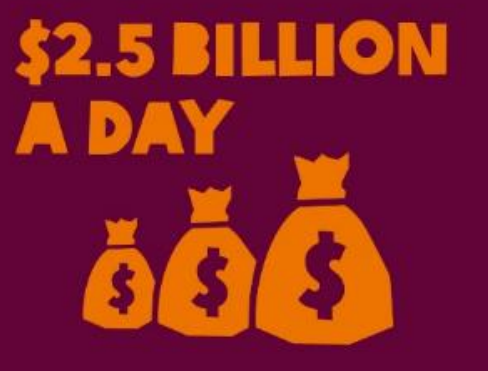

EXTREME POVERTY IS INCREASING

IN SUB-SAHARAN AFRICA.

This new evidence also

shows that 3.4 billion people (almost half of humanity] have barely escaped extreme poverty and are living on less than

\section{$\$ 5.50$ A DAY}

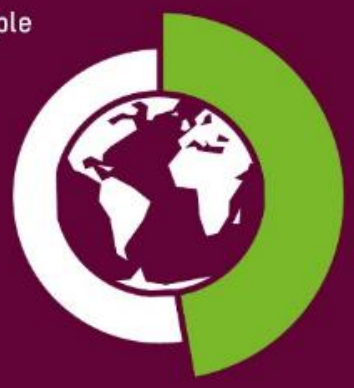

MEN OWN 50\% MORE OF THE TOTAL WEALTH THAN WOMEN.

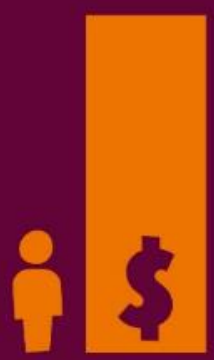

A recent study of 13 developing countries found that:

SPENDING ON EDUCATION AND HEALTH ACCOUNTED FOR 69\% OF THE TOTAL REDUCTION OF INEQUALITY.
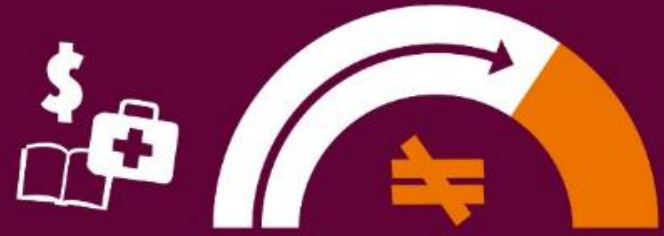

GETTING THE RICHEST 1\% TO PAY JUST 0.5\% EXTRA TAX ON THEIR WEALTH WOULD RAISE MORE MONEY THAN IT WOULD COST TO:

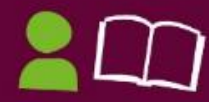

Educate all the

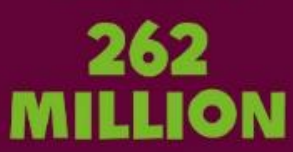

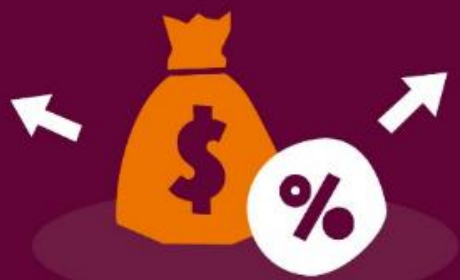

children out of school..

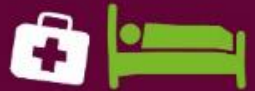

..and provide healthcare that would save the lives of

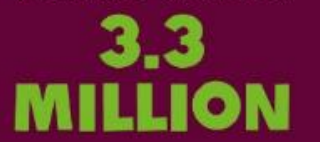

people.

Sources:

Forbes. (2018); Methodology Note. ${ }^{1}$

World Bank. (2018a). ${ }^{2}$

A. Shorrocks, J. Davies and R. Lluberas. (2018). World Wealth Report 2018. ${ }^{3}$

N. Lustig. (2015). ${ }^{4}$

Methodology Note, op cit. ${ }^{5}$ 


\section{KEY RECOMMENDATIONS}

Governments should listen to ordinary citizens and take meaningful action to reduce inequality. All governments should set concrete, timebound targets and action plans to reduce inequality as part of their commitments under Sustainable Development Goal (SDG) 10 on inequality. These plans should include action in the following three areas:

1. Deliver universal free health care, education and other public services that also work for women and girls. Stop supporting privatization of public services. Provide pensions, child benefits and other social protection for all. Design all services to ensure they also deliver for women and girls.

2. Free up women's time by easing the millions of unpaid hours they spend every day caring for their families and homes. Let those who do this essential work have a say in budget decisions and make freeing up women's time a key objective of government spending. Invest in public services including water, electricity and childcare that reduce the time needed to do this unpaid work. Design all public services in a way that works for those with little time to spare.

3. End the under-taxation of rich individuals and corporations. Tax wealth and capital at fairer levels. Stop the race to the bottom on personal income and corporate taxes. Eliminate tax avoidance and evasion by corporates and the super-rich. Agree a new set of global rules and institutions to fundamentally redesign the tax system to make it fair, with developing countries having an equal seat at the table. 
Mukesh Ambani ranks $19^{\text {th }}$ in the Forbes 2018 billionaire list and is the richest Indian. His residence in Mumbai, a towering 570-foot building, is worth $\$ 1 \mathrm{bn}$ and is the most expensive private house in the world. ${ }^{6}$

Pratima, who lives in a slum in Patna, eastern India, lost both her twins due to delays and scarce resources in her nearest clinic. Poor women like Pratima have to give birth without proper maternal healthcare, leaving them vulnerable to complications, neglect and stillbirth as a result.

Jeff Bezos, the founder of Amazon, is the richest man in the world, with a fortune of $\$ 112 \mathrm{bn}$ on the 2018 Forbes list. Just $1 \%$ of his total wealth is the equivalent of almost the whole health budget of Ethiopia, a country of 105 million people. He recently said that he has decided to invest his fortune in space travel, as he can't think of anything else to spend his money on. ${ }^{7}$

Zay is a shrimp processing worker in Thailand. The shrimp Zay peels is supplied to large retailers like Whole Foods supermarkets, now owned by parent company, Amazon. At the end of a shift, the exhaustion Zay feels after peeling shrimp for 12 or 13 hours can leave him almost immobile. 'They are using the workers,' says Zay. Zay is lucky if he earns more than \$15 in a day.

\section{PUBLIC GOOD, NOT PRIVATE WEALTH}

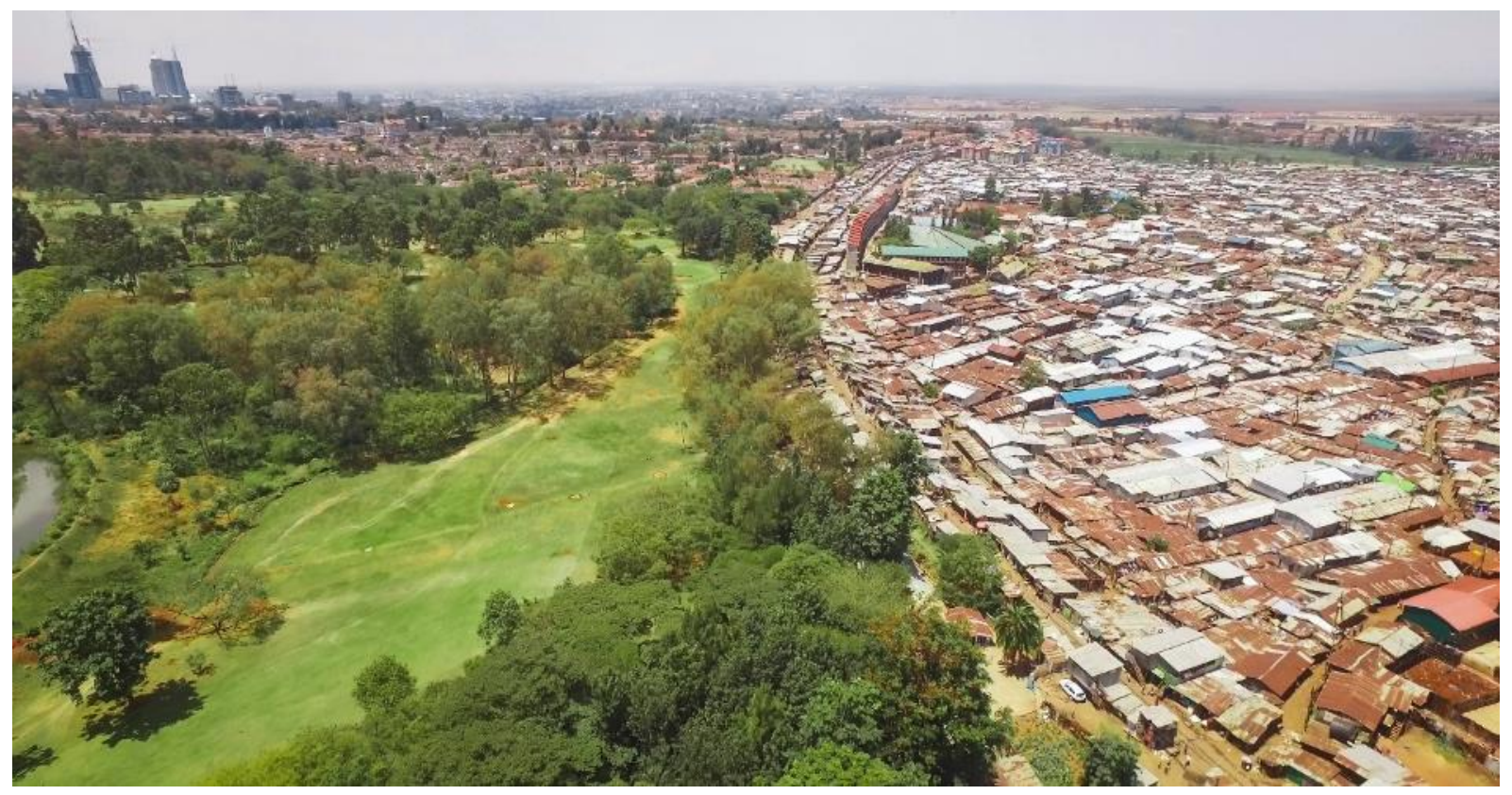

The chaos, noise, and density of the Kibera slum is neatly juxtaposed with the orderly calm green of the Royal Nairobi Golf Club, which opened in 1906. Photo: Johnny Miller.

The gap between rich and poor is pulling us apart. It stops us from beating poverty and achieving equality between women and men. Yet most of our political leaders are failing to reduce this dangerous divide. It does not have to be this way. Inequality is not inevitable - it is a political choice. ${ }^{8}$ Concrete steps can be taken to reduce it. 
This report focuses on the unparalleled power of universal public services like education and health in tackling poverty and reducing inequality. ${ }^{9}$ Universal public services are the foundation of free and fair societies. If they choose to do so, governments can deliver life-saving public services for all their citizens.

There is a growing consensus ${ }^{10}$ that the wealth of individuals and corporations is not being adequately taxed, and instead taxes are falling disproportionately on working people. For every dollar of tax revenue, on average just 4 cents are made up of revenue from wealth taxes. ${ }^{11}$

The fortunes of the world's super-rich have grown to record levels. ${ }^{12}$ By taxing wealth more fairly, enough money could be raised globally to ensure that every child goes to school and no one is bankrupted by the cost of medical treatment for their families. In doing this, it is possible to build a more Human Economy- one that is more equal and values what truly matters.

\section{Progress in fighting poverty slows dramatically}

One of the great achievements in recent decades has been the huge reduction in the numbers of people living in extreme poverty, defined by the World Bank as $\$ 1.90$ per person per day. Yet new evidence from the World Bank shows that the rate of poverty reduction has halved since 2013. ${ }^{13}$ Extreme poverty is actually increasing in sub-Saharan Africa. This new evidence also shows that much of humanity has barely escaped poverty, with just under half the world's population -3.4 billion people - subsisting on less than $\$ 5.50$ a day, which is the World Bank's new poverty line for extreme poverty in upper-middle-income countries. ${ }^{14}$ The Bank finds that women are more often among the poorest people, particularly during their reproductive years, because of the level of unpaid care work they are expected to do. ${ }^{15}$

This is a direct result of inequality, ${ }^{17}$ and of prosperity accruing disproportionately to those at the top for decades. The World Inequality Report 2018 showed that between 1980 and 2016 the poorest $50 \%$ of humanity only captured 12 cents in every dollar of global income growth. By contrast, the top $1 \%$ captured 27 cents of every dollar. ${ }^{18}$ The lesson is clear: to beat poverty, we must fight inequality.

The human cost of inequality is devastating. Today:

- 262 million children will not be allowed to go to school. ${ }^{19}$

- Almost 10,000 people will die because they cannot access healthcare. ${ }^{20}$

- 16.4 billion hours of unpaid care work will be done, the majority by women in poverty. ${ }^{21}$

Governments face a stark choice today - a choice between a life of dignity for all their citizens or continued extreme wealth for a tiny few.
'In the course of history, there comes a time when humanity is called to shift to a new level of consciousness... to reach a higher moral ground. A time when we have to shed our fear and give hope to each other. That time is now.'

- Dr Wangari Maathai, founder of the Green Belt Movement, 2004 Nobel Peace Prize Laureate

'If a free society cannot help the many who are poor, it cannot save the few who are rich.' - John F. Kennedy, Inaugural Address, Jan. 20, 1961.

Roberta is a police officer. She gave birth to twins in Kenyatta National Hospital, Nairobi. Sadly, there were many complications and both babies died. Unable to pay the bill, Roberta was held captive in the hospital and the authorities refused to release her babies' bodies until the bill was settled. ${ }^{16}$ 


\section{Boomtime for the world's billionaires}

It is 10 years since the financial crisis that shook our world and caused enormous suffering. In that time, the fortunes of the richest have risen dramatically:

- In the 10 years since the financial crisis, the number of billionaires has nearly doubled. ${ }^{22}$

- The wealth of the world's billionaires increased by $\$ 900 \mathrm{bn}$ in the last year alone, or $\$ 2.5 \mathrm{bn}$ a day. Meanwhile the wealth of the poorest half of humanity, 3.8 billion people, fell by $11 \% .^{23}$

- Billionaires now have more wealth than ever before. Between 2017 and 2018, a new billionaire was created every two days. ${ }^{24}$

- Wealth is becoming even more concentrated - last year 26 people owned the same as the 3.8 billion people who make up the poorest half of humanity, down from 43 people the year before. ${ }^{25}$

- The world's richest man, Jeff Bezos, owner of Amazon, saw his fortune increase to $\$ 112 \mathrm{bn}$. Just $1 \%$ of his fortune is the equivalent to the whole health budget for Ethiopia, a country of 105 million people. ${ }^{26}$

- If all the unpaid care work done by women across the globe was carried out by a single company, it would have an annual turnover of $\$ 10$ trillion $^{27}-43$ times that of Apple. ${ }^{28}$

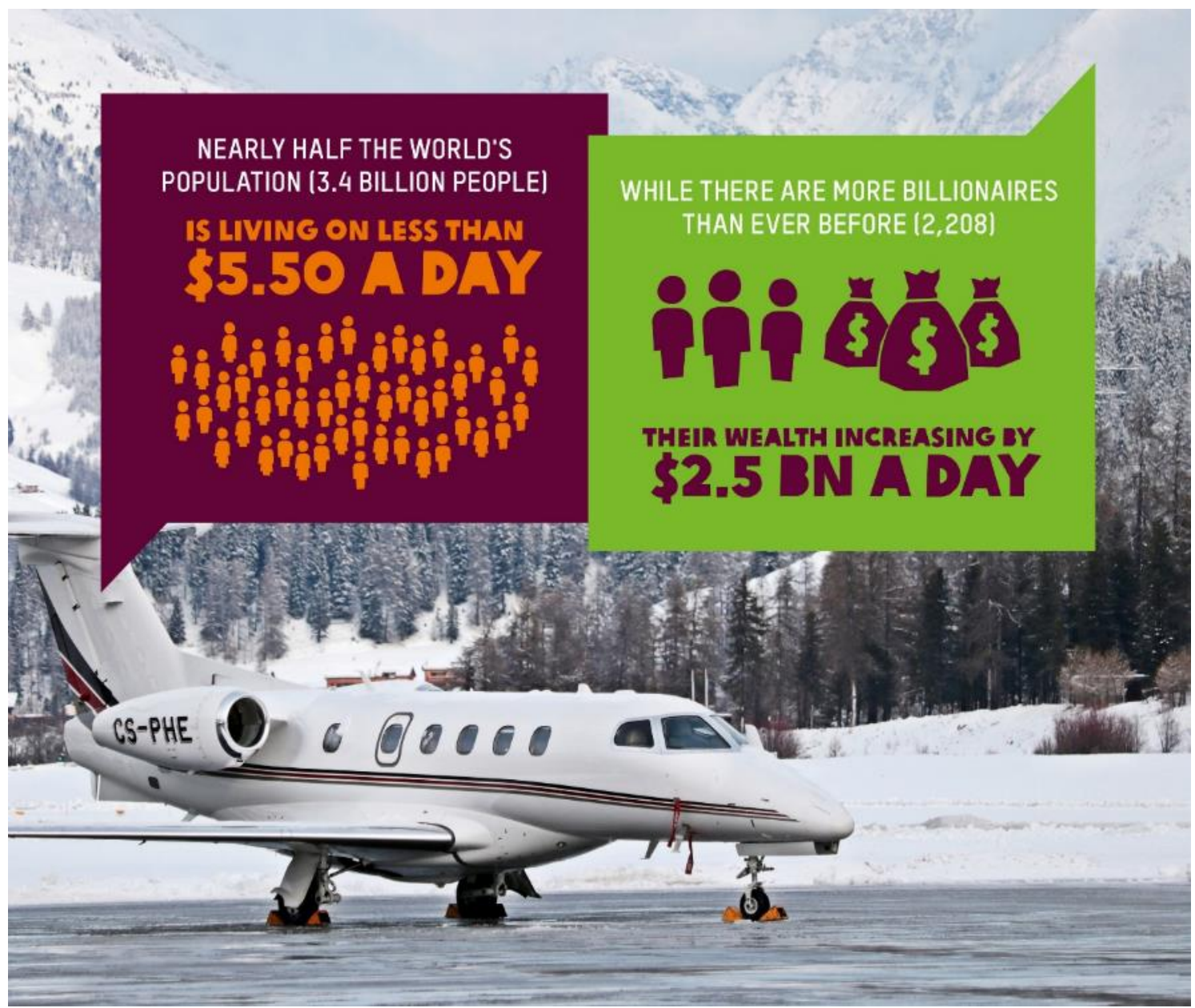

Source: World Bank (2018a) ${ }^{29}$ and methodology note. ${ }^{30}$ Photo: A private jet in the resort town of St Moritz, Switzerland. Credit: Pixabay. 
While the richest continue to enjoy booming fortunes, they are also enjoying some of the lowest levels of tax in decades - as are the corporations that they own:

- Wealth is particularly undertaxed. Only 4 cents in every dollar of tax revenue comes from taxes on wealth.

- In rich countries, the average top rate of personal income tax fell from $62 \%$ in 1970 to $38 \%$ in $2013 .{ }^{31}$ In developing countries, the average top rate of personal income tax is $28 \%$. $^{32}$

- In some countries like Brazil ${ }^{33}$ and the $\mathrm{UK},{ }^{34}$ the poorest $10 \%$ are now paying a higher proportion of their incomes in tax than the richest $10 \%$.

- Governments should focus their efforts on raising more from the very wealthy to help fight inequality. For example, getting the richest to pay just $0.5 \%$ extra tax on their wealth could raise more money than it would cost to educate all 262 million children out of school and provide healthcare that would save the lives of 3.3 million people. ${ }^{35}$

- The super-rich are hiding $\$ 7.6$ trillion from the tax authorities. ${ }^{36}$

'Financing the education of the poorest children is saving lives and it is constructing the future of the world.'

- Illiassou Boubagar, ROTAB Alliance for Budget Transparency, Niger

'Education is not a way to escape poverty. It is a way to fight it.'

- Julius Nyerere, founding

President of Tanzania Corporates also hide large amounts offshore. Together this deprives developing countries of $\$ 170 \mathrm{bn}$ a year. ${ }^{37}$

\section{Figure 1: The breakdown of tax revenues}
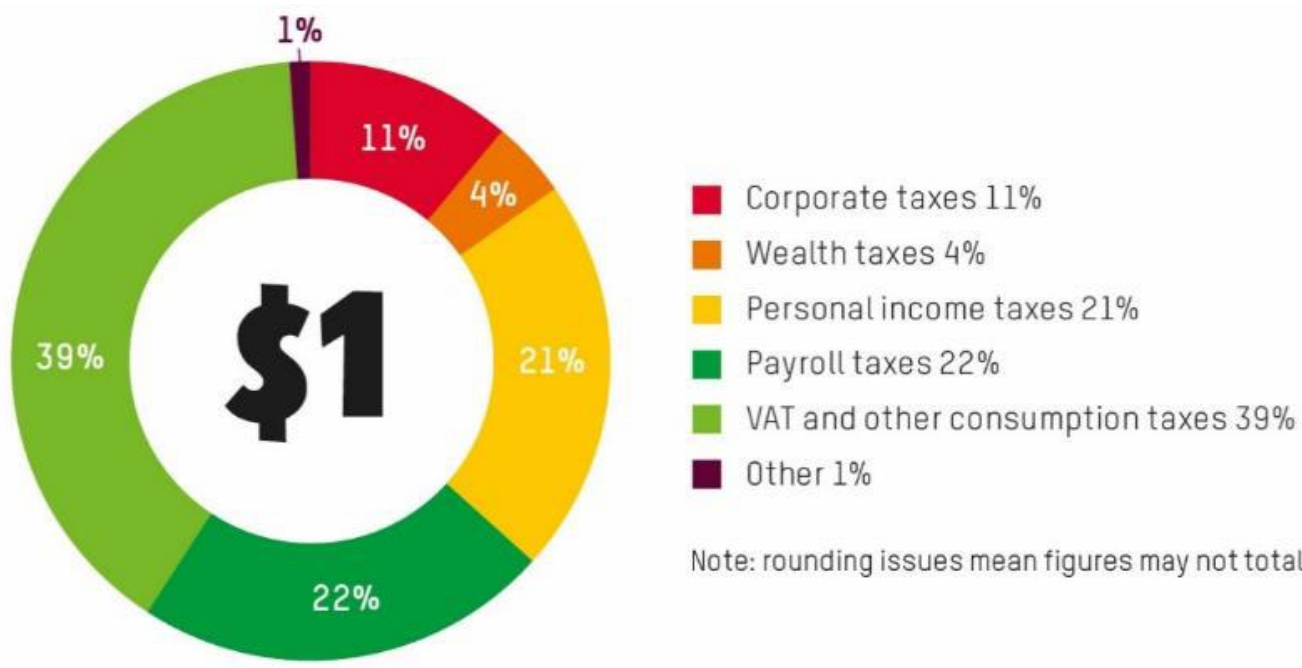

Source: Oxfam calculations based on OECD data available for 35 OECD and 43 non-OECD countries for $2015 .{ }^{38}$

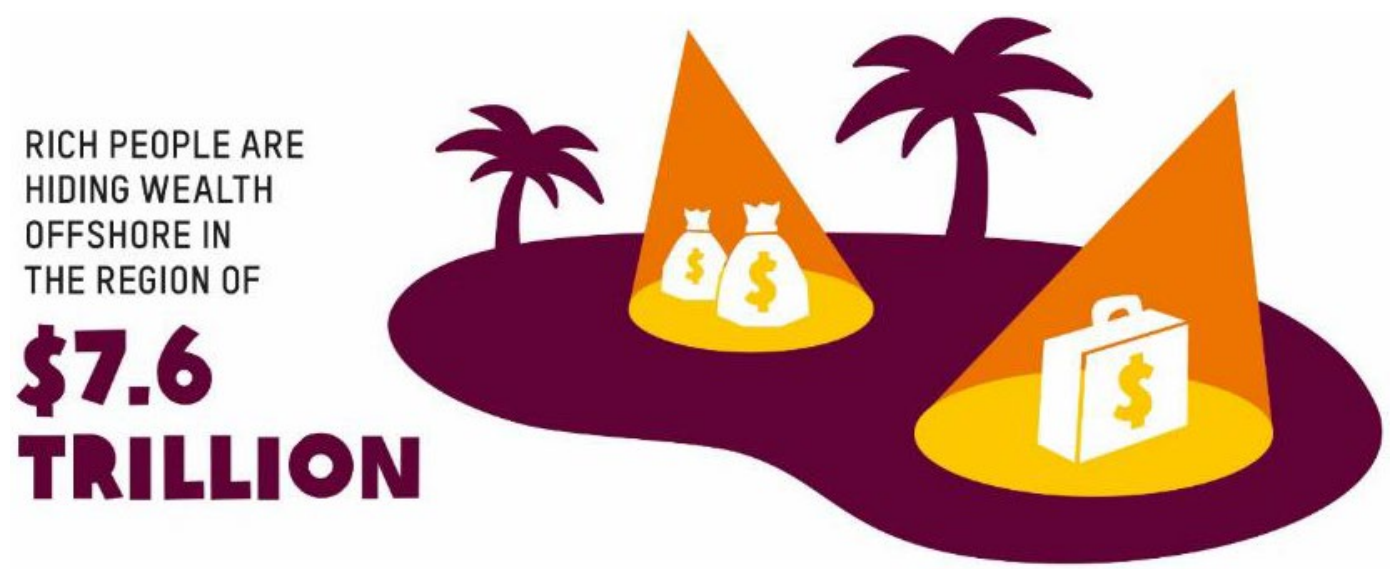

Source: G. Zucman. (2015). and the methodology note for Oxfam's 2018 Davos report. ${ }^{39}$ 


\section{THE DIVIDE THAT THREATENS TO TEAR US APART}

Respected voices have warned that across the world, from the US to Brazil, from Europe to the Philippines, inequality is contributing to a poisoning of our politics. In recent years, we have seen crackdowns on freedom of speech and democracy by governments worldwide. ${ }^{41}$ The Council on Foreign Relations has highlighted the evidence that the gap between rich and poor is helping to fuel authoritarianism. ${ }^{42}$ Rather than working to heal the divide between rich and poor, some leaders are instead seeking to vilify immigrants, other ethnic groups, other nations, women and people in poverty. In more unequal countries, trust ${ }^{43}$ is lower and crime higher. ${ }^{44}$ Unequal societies are more stressed, less happy and have higher levels of mental illness. ${ }^{45}$
II recently visited a very rich person in Brazil. They lived in a beautiful apartment, with floor to ceiling windows and incredible views. But we had to go through three security checks to get into the building. The windows were covered in bars. I am sure they pay very low taxes, but they have to live in a cage. I could never live like that. I may pay more tax in Denmark, but all I have outside my door in Copenhagen is flowers.'

- Djaffar Shalchi, Danish multimillionaire and founder of The Human Act Foundation, who launched the Move Humanity campaign $^{40}$

IN THE US, SINGLE WHITE MEN OWN

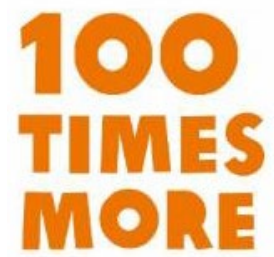

WEALTH THAN SINGLE HISPANIC WOMEN

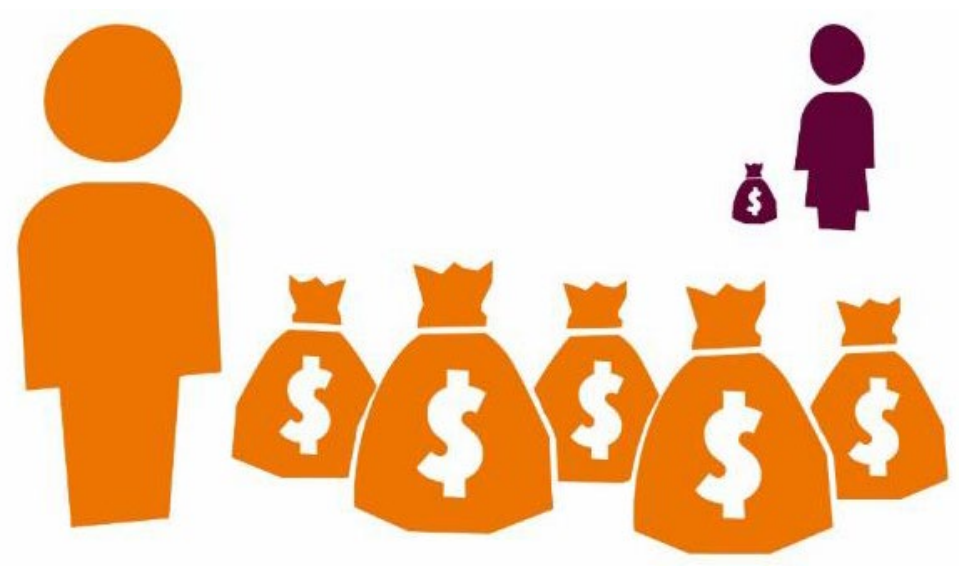

Source: M. Chang. (2015). ${ }^{46}$

\section{Inequality is sexist}

This economic divide both drives the gap between women and men and is driven by it. Economically unequal countries are countries where women and men are more unequal too. Societies in which the gap between rich and poor is much lower are those in which women are treated more as equals. ${ }^{47}$ Gender inequality is neither an accident nor something new. Our economic rules have been written by rich and powerful men in their own interests. The neo-liberal economic model of today has made this worse - cuts to public services, cuts to taxes for the richest individuals and corporations, and a race to the bottom on wages have all hurt women more than men.

Most of the world's richest people are men. ${ }^{48}$ Globally, women earn 23\% less than men $^{49}$ and men own $50 \%$ more of the total wealth than women. ${ }^{50}$

Most profoundly, our economic prosperity is dependent on the huge but unrecognized contribution made by women through unpaid care work. 


\section{Box 1: Unpaid care and inequality}

Our economies are built on millions of hours of unpaid labour carried out every day. Because of unjust social attitudes, this unpaid care work is overwhelmingly done by women and girls - time spent caring for children, the elderly and the sick; cooking, cleaning, and collecting water and firewood. If all the unpaid care work done by women across the globe was carried out by a single company, it would have an annual turnover of $\$ 10$ trillion $^{51}$ - 43 times that of Apple. ${ }^{52}$ Women's unpaid contribution to the health sector alone is estimated to be worth approximately $3 \%$ of GDP in low-income countries. ${ }^{53}$

This work steals time from women, contributes to poor health and leaves them unable to take advantage of educational, political and economic opportunities. Poor women have the highest burden of unpaid work. Until we do something about it, neither economic nor gender equality is possible.

Inequality also has profound implications for the future of our children and the opportunities they will have to live a better and longer life.

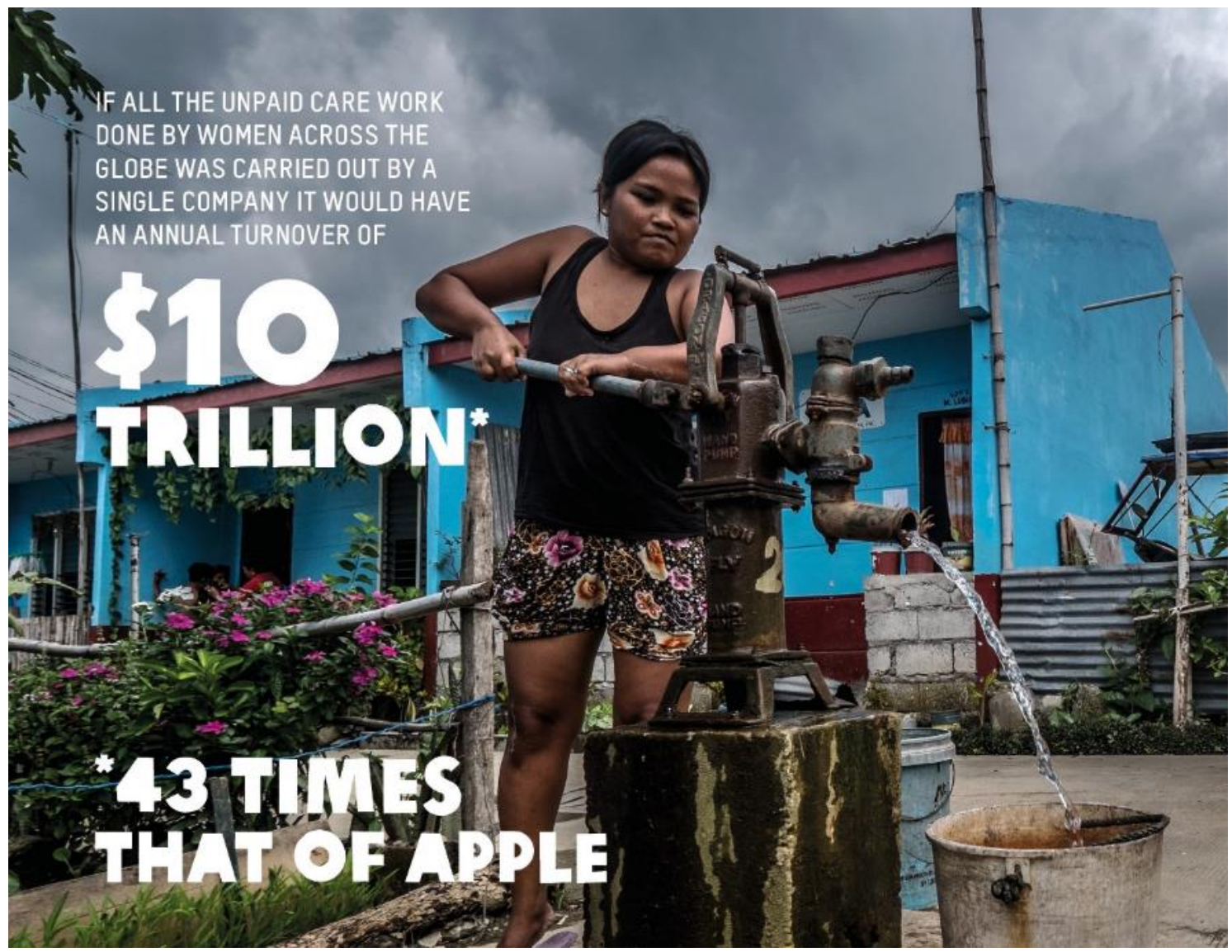

Figure calculated based on Apple's reported annual revenue in 2017 ( $\$ 229.3 \mathrm{bn})$; see endnote for source. ${ }^{54}$ Photo: Rosalyn Martinez collects water from a water pump in the GMA Resettlement Area, North Tacloban, Philippines. The site was built to relocate families after Typhoon Haiyan, but many residents say they are in an even more vulnerable situation now and lack basic services such as reliable and clean water. Credit: Aurelie Marrier d'Unienville/Oxfam. 


\section{Talent is everywhere, opportunity isn't}

The opportunity for every child to learn and to make the most of their talents is at the heart of a fairer society. Yet in country after country it is wealth, not talent, that dictates a child's educational destiny. In Kenya, a boy from a rich family has a one in three chance of continuing his studies beyond secondary school. A girl from a poor family has a one in 250 chance of doing so. ${ }^{55}$ On average in Kenya, a child from a rich family will have double the amount of education compared to a child from a poor family. ${ }^{56}$ In the U.S, the American Dream has become a myth, with social mobility lower today than it has been in decades. ${ }^{57}$

This reality is failing individual children, each of whom has a right to education. It is also failing society, as a generation of talented poor girls and boys cannot fulfil their promise and contribute fully to human progress. Brilliant doctors, teachers or entrepreneurs are instead herding goats or collecting water. Humanity faces unprecedented challenges. Yet instead of utilizing the talents of all of people, inequality means we are squandering this potential.

\section{IN NEPAL, A CHILD FROM A POOR FAMILY IS}

\section{THREE TIMES MORE LIKELY TO DIE BEFORE THEY ARE FIVE}
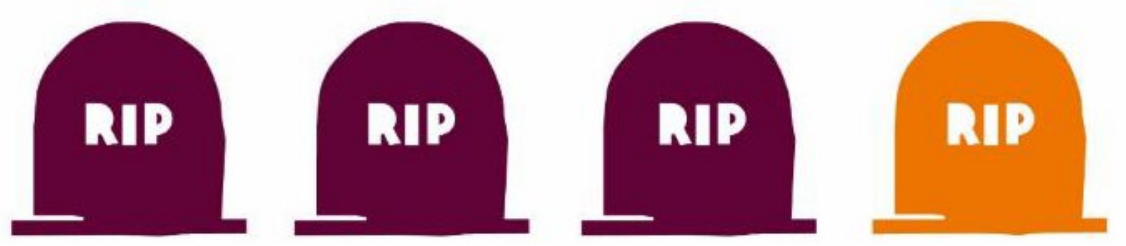

THAN A

CHILD FROM

A RICH

FAMILY

Source: Nepal Ministry of Health. ${ }^{58}$

\section{Denied a longer life}

In most countries - both developed and developing - having money is a passport to better health and a longer life, while being poor all too often means more sickness and an earlier grave. In Nepal, a child from a poor family is three times more likely to die before they are five than a child from a rich family. ${ }^{59}$

In India, a so-called low-caste woman can expect to live almost 15 years less than a so-called upper-caste woman. ${ }^{61}$ Life expectancy in one of the poorest parts of London is six years less than it is in one of the capital's richest neighbourhoods, just a few miles away. ${ }^{62}$ Life expectancy in the richest parts of Sao Paulo, Brazil, is 79 years. In one of the poorest areas

'Of all the forms of inequality, injustice in health is the most shocking and inhuman. ${ }^{\prime} 0$ - Martin Luther King of the city it is 54 years. ${ }^{63}$

It is hard to think of a greater injustice than living over twenty-five years less, simply because you are poor. 


\section{It doesn't have to be this way}

Inequality is not inevitable. There is no law of economics that says the richest should grow ever richer while people in poverty die for lack of medicine. It makes no sense to have so much wealth in so few hands, when those resources could be used to help all of humanity. Inequality is a political and a policy choice. ${ }^{64}$

This paper focuses on one of the most powerful things a government can do to reduce the gap between the super-rich and ordinary people: provide universal public services and social protection, paid for by fair taxation.

\section{THE POWER OF PUBLIC SERVICES TO FIGHT INEQUALITY}

Classrooms with teachers. Clinics with nurses and doctors. Working taps and clean toilets. A basic pension at the end of a hard-working life.

Education, health, water, pensions, child benefits that are available to all people regardless of gender, caste, ethnicity or disability. Public services and social protection benefits such as these can be engines of equality, working to transform people's lives and unlock potential, pull societies together and close the gap between rich and poor and between women and men.

Public services can bring true freedom: freedom from fear of ill health without care; freedom from illiteracy, which prevents so many from actively participating and progressing in their daily lives; and the freedom of knowing that you and your family will be supported if you fall on hard times.

IN POOR COUNTRIES DOING THE MOST TO STOP POOR WOMEN DYING IN CHILD BIRTH:

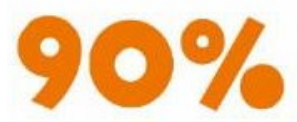

OF THE MEDICAL CARE IS PROVIDED BY THE PUBLIC SECTOR...

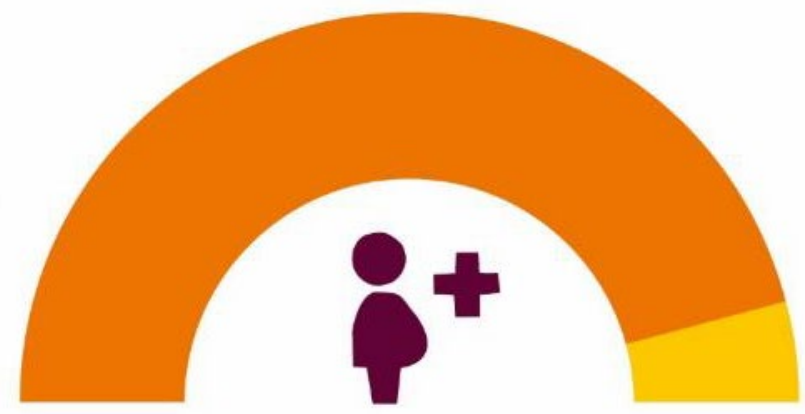

AND

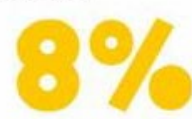

BY THE PRIVATE SECTOR

Source: Oxfam calculations. ${ }^{65}$ Note: figure does not include 'at home' and 'other' as places of delivery, which comprise the final $2 \%$. For more details, see methodology note.

Public services and social protection reduce poverty and inequality. Evidence from 150 countries spanning a period of over 30 years ${ }^{66}$ shows that, overall, investment in health, education and social protection reduces the gap between rich and poor. One recent review of 13 developing countries found that spending on education and health accounted for $69 \%$ of total reduction of inequality. ${ }^{67}$ If all children left 
school with basic reading skills, 171 million people could be lifted out of extreme poverty. ${ }^{68}$ The International Monetary Fund (IMF) has identified public spending on health, education and social protection as among the most important tools available to governments to reduce inequality and poverty. ${ }^{69}$ Everyone in society stands to benefit, with less crime, more trust, ${ }^{70}$ better health and longer, happier lives. ${ }^{71}$

Public services can be great equalizers, giving everyone, regardless of wealth or income, a fair shot at a decent life. Schools can be places where the children of rich and poor families become friends and the barriers of inequality are broken down. Clinics can be places where poor and rich alike know they will receive the best care available, regardless of their ability to pay.

Public services can also reduce the gap between women and men. Education can increase women's self-confidence, economic opportunities and decision-making power. ${ }^{72}$ Good-quality, free healthcare is essential for women and girls to be able to make decisions about their own lives, to increase their prospects of escaping poverty and reduce their chances of dying from preventable illness. ${ }^{73}$ Cleaned piped water saves women many hours spent collecting it and protects from disease. ${ }^{74}$ Conversely, underfunded and low-quality public services that are blind to the needs of women and girls can widen the gender gap.

\section{The status quo: progress, but too slow and very unequal}

\section{Box 2: Healthcare in India}

In India, the highest-quality medical care is only available to those who have the money to pay for it. ${ }^{75}$ The country is a top destination for medical tourism. ${ }^{76}$ At the same time, levels of public spending on health are some of the lowest in the world. The poorest Indian states have infant mortality rates higher than those in sub-Saharan Africa. ${ }^{77}$

The way services like health and education are delivered and the way in which pensions and other welfare payments are organized is critical to how much they reduce the gap between rich and poor.

In recent decades, public services, especially in developing countries, have delivered some remarkable results. Since 1990, 2.6 billion people have gained access to improved drinking water. ${ }^{78}$ Primary school enrolment is now almost universal in most countries, with as many girls enrolling as boys. ${ }^{79}$ Since 1990 , the number of children dying before their fifth birthday has halved. ${ }^{80}$

Yet despite these important strides there is still a huge way to go, and progress has been very unequal. In developing countries, children from the richest families are $32 \%$ more likely to complete primary school than children from the poorest families. ${ }^{81}$ Across low- and middle-income countries, it is estimated that 3.6 million deaths each year can be attributed to lack of access to healthcare. ${ }^{82}$ Evidence from 137 
developing countries shows that a child from a poor family is on average twice as likely to die before their fifth birthday than a child from a rich family. ${ }^{83}$

In many countries, public schools and clinics are often poorly staffed, underfunded and of very low quality. They are kept afloat by committed teachers, doctors and nurses. Social protection is often miserly and excludes many who need it. Too often, services ignore the specific needs of women. Such low-quality public services end up reinforcing and increasing inequality.

\section{IN SUB-SAHARAN AFRICA, THE POPULATION IS STILL LACKING ACCESS TO BASIC PUBLIC SERVICES LIKE WATER AND ELECTRICITY}

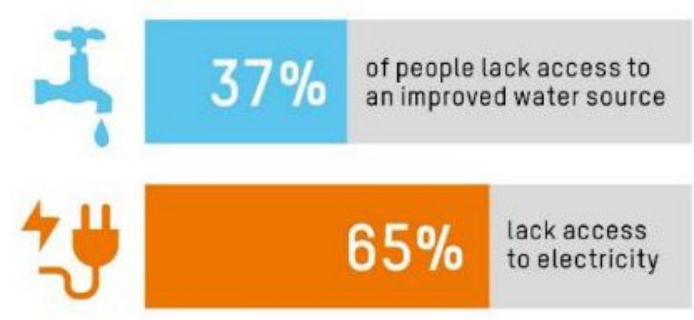

\section{THIS GREATLY INCREASES \\ THE AMOUNT OF TIME POOR HOUSEHOLDS SPEND ON UNPAID CARE TASKS}

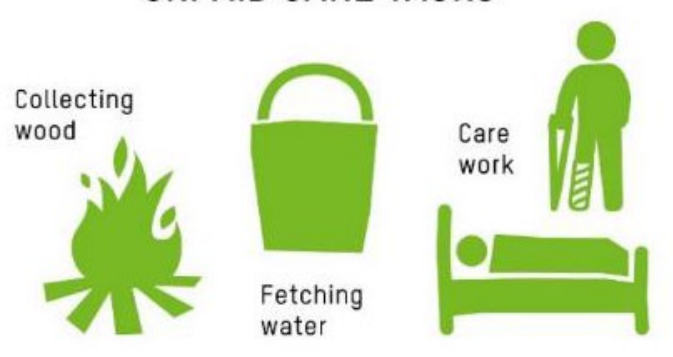

Source: V. Esquival and A. Kaufmann. (2017). ${ }^{84}$

For some time, the view of institutions like the World Bank was that public services should be rationed and minimal, and that the private sector is often a better provider. It was argued that individuals should pay for their schools and hospitals, market mechanisms should be used to organize services, and that social protection should be very limited and targeted only at the very poorest people. ${ }^{85}$ While some of the rhetoric, programming and advice has changed, including notably from the IMF, 86 change in practice has been slower. This trend is too often compounded by the influence of elites over politics and governments, skewing public spending in the wrong direction and ensuring that it benefits the already wealthy rather than those who need it most. ${ }^{87}$

\section{The goal: free, quality public services for all}

It is time to focus on what works. To most effectively reduce the gap between rich and poor, public services need to be universal, free, public, accountable and to work for women.

\section{Universal}

Costa Rica, Thailand, Sri Lanka and others have shown that universal public services can be affordable for developing nations. ${ }^{88}$ Universal social protection and public services played a pivotal role in state- and nation-building in Western Europe. ${ }^{89}$ Trying to target the poorest people often has the opposite effect, with many of those who should benefit being left out. For example, Indonesia's targeted social protection scheme excludes $93 \%$ of those who should qualify for it. ${ }^{90}$

'It only takes such a small amount to save so many lives. If they (the wealthiest) pay their taxes it doesn't just benefit the poor person, it helps the family and the economy. For example, if a poor child with an eye problem gets the health care they can need, he or she can continue going to school, learn more, get a higher education and a better future.'

- Dr Lê thị Cẩm Thanh, Vice Director of the Government Eye Hospital of Can Tho province, Vietnam.

'It is my aspiration that health finally will be seen not as a blessing to be wished for, but as a human right to be fought for.'

- Kofi Annan 


\section{Free at the point of use}

User fees for healthcare can be a life-or-death issue. Each year, many die or suffer unnecessarily because they cannot afford healthcare, and 100 million people are forced into extreme poverty by healthcare costs. ${ }^{91}$ In countries like Kenya, Democratic Republic of the Congo (DRC) and India, at times some poor people are held prisoner in hospital until they can pay; sometimes they are even chained. ${ }^{92}$ In one study in the DRC, over a six-week period in $2016,54 \%$ of women who had given birth were detained for the non-payment of user fees. In many cases, women and babies are held for months and are denied ongoing healthcare until their bills can be settled..$^{93}$ Similarly, with education, school fees can stop children going to school, and especially girls. ${ }^{94}$ Women and girls lose out the most when fees are charged for public services: in many societies, their low social status and lack of control over finances means they are last in line to benefit from education or medical care. ${ }^{95}$

\section{Public, not private}

To succeed, countries need to scale up the public delivery of services. When publicly delivered services are made to work, the scale and speed of their impact on poverty reduction cannot be matched. ${ }^{96}$ Successful developing countries have demonstrated the potential and ability of publicly delivered services to be both universal and pro-poor. In the poor countries that are doing the most to stop poor women dying in childbirth, $90 \%$ of care is provided by the public sector. ${ }^{97}$

\section{Box 3: Thailand's progress on universal healthcare}

Thailand introduced universal health coverage in 2002 for its population of 65 million people, with a per capita income similar to that of the US in 1930. ${ }^{98}$ The Thai government employs 180,000 nurses $^{99}$ and 50,000 doctors. ${ }^{100}$ Over $80 \%$ of all care is delivered by the state. Funded by progressive taxation, quality health services are available free to everyone, and benefit the poorest people most. ${ }^{101}$ The World Bank and some donor governments are upbeat about the possibility of public-private partnerships (PPPs) ${ }^{102}$ and private provision as alternatives to government-funded services. Yet research by Oxfam ${ }^{103}$ and other NGOs ${ }^{104}$ has shown clearly that education, health and other public services delivered privately and funded through PPPs are not a viable alternative to government delivery of services. Instead they can drive up inequality and drain government revenues. Even the IMF is now warning of the sizeable fiscal risks of pursuing PPP approaches. ${ }^{105}$

\section{Working for women}

Governments should prioritize services that are most important for women, including those that reduce the burden of unpaid care work. Public services can promote women as workers. They can support women and girls as service users, protecting them from abuse. They should work with women's rights organizations to make sure the services are delivering for women. Well-designed public services can challenge accepted stereotypes about the roles of women and men rather than
'Deficiencies in basic education [in India] cannot be met by the expansion of private schools, which have not been able to play that role anywhere else.' - Amartya Sen, Nobel Prize Winning Economist 
reinforce them; education can empower girls to challenge inequality rather than accept it.

\section{Accountable to those they serve}

To effectively fight economic inequality, public services need to be accountable and responsive to citizens. In many countries, Oxfam is working with allies to support citizens in demanding better and more accountable services. In Mozambique, since 2011 Oxfam allies have tracked spending on education, health and other public services, leading to improvements in services. ${ }^{106}$

\section{Box 4: Education public-private partnerships in Pakistan: a dangerous diversion from public education}

Pakistan has 24 million children out of school. Only $15 \%$ of poor rural girls finish primary schooling. To tackle this, Punjab state is no longer building any new public schools, but instead investing in a public-private partnership (PPP). The key aim was to get more of the 5.5 million out-of-school children in Punjab into education. ${ }^{107}$

Oxfam's research ${ }^{108}$ into the education PPP found that only $1.3 \%$ of children in the private schools surveyed had previously been out of school. The following are quotes from private school principals interviewed during the research:

'We don't have any [formerly] out-of-school children in this school. The ones in the community don't want to study and can be a waste of our time.'

'The poor go to government schools in the area. They cannot afford any expenditure on education. We as school owners cannot include the poorest of the poor in this school with other kids. It's not like a charity; we have limited funds from the PPP, and I also need to earn a livelihood from this.'
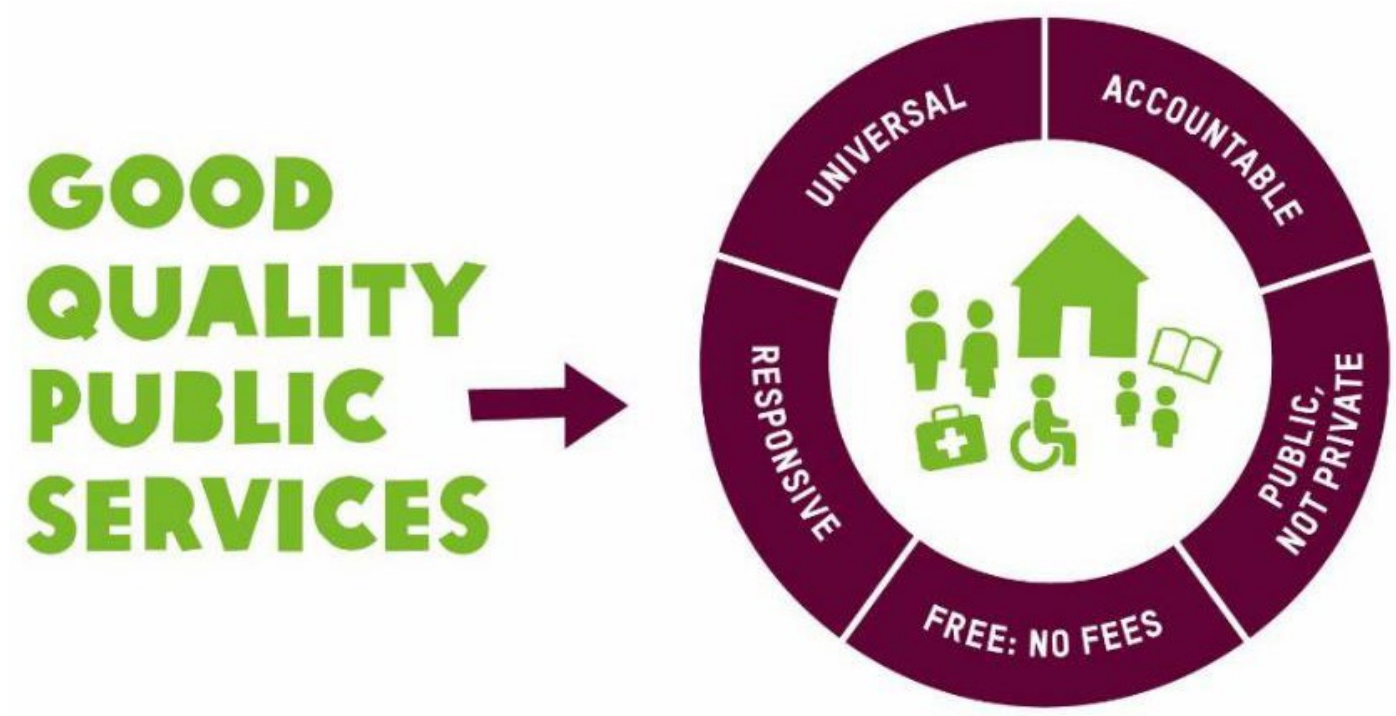


\section{Taxing those who can afford to pay}

The richest people and the corporations they own are undertaxed in today's world. The top rates of income tax, and rates of inheritance tax and corporate tax have fallen in many rich countries and remain low in most developing countries. ${ }^{110}$ If this were reversed, most governments would have enough resources to provide universal public services.

Additional tax revenues raised from the richest people in rich countries could be used to support the poorest countries through increases in aid.

Taxes on wealth, like inheritance or capital gains tax, have been reduced and eliminated in many rich countries and are often barely implemented in most developing ones. They are often the target of hostile commentators and politicians, ${ }^{111}$ attacked, despite clear evidence that they primarily impact the richest people and not ordinary citizens. ${ }^{112}$

\section{Figure 2: Tax revenue change 2007-2015 (\%GDP)}

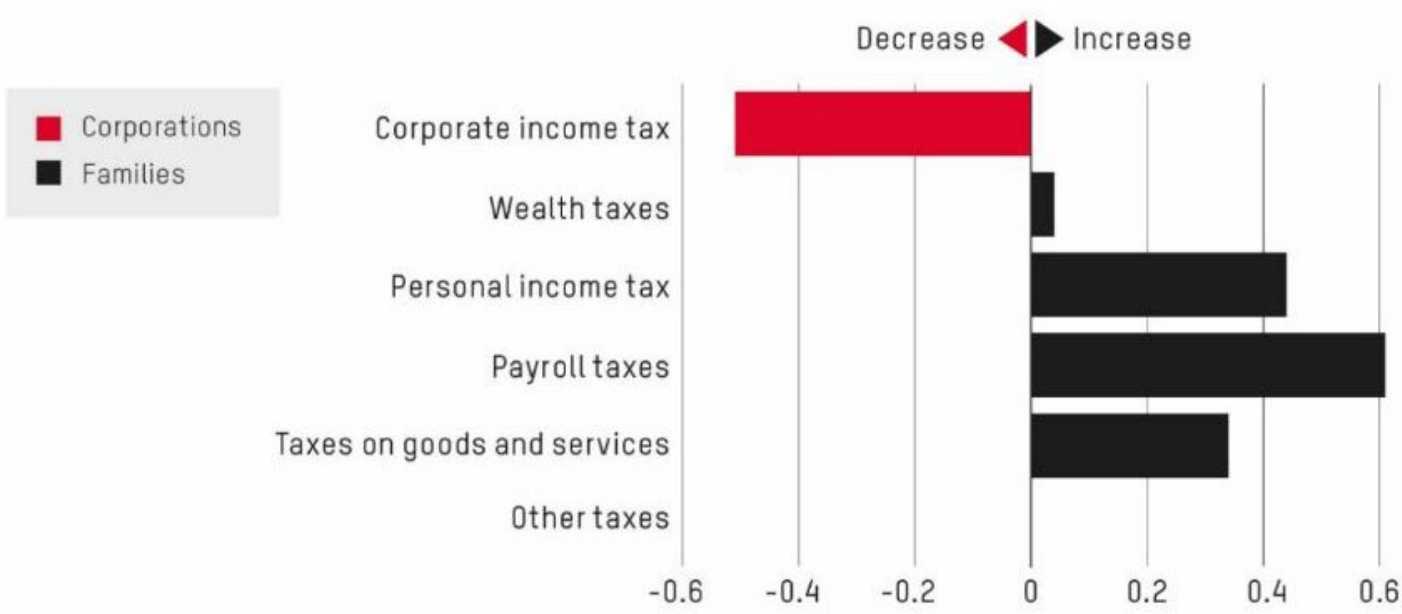

Oxfam calculations based on OECD data available for 35 OECD and 43 non-OECD countries (unweighted averages). ${ }^{113}$ Axis figures represent $\mathrm{pp}$ - percentage points of GDP.

In addition, governments have been reducing both the top rate of personal income tax and the rate of corporate income tax over the long term. As recently as 1980, the top rate of personal income tax in the US was $70 \%$. Today it is almost half that, at $37 \% .{ }^{114}$ The numerous exemptions and loopholes mean the rates that rich people and corporations actually pay are lower still.

As a result, in some countries the richest people are paying lower rates of tax than they have in a century. In Latin America, for example, the effective tax rate for the top $10 \%$ of earners is just $4.8 \% .{ }^{115}$

In some countries, when tax paid on incomes and tax paid on consumption (value-added tax or VAT) are both considered, the richest $10 \%$ are paying a lower rate of tax than the poorest $10 \%$. 
Figure 3: Effective tax rates

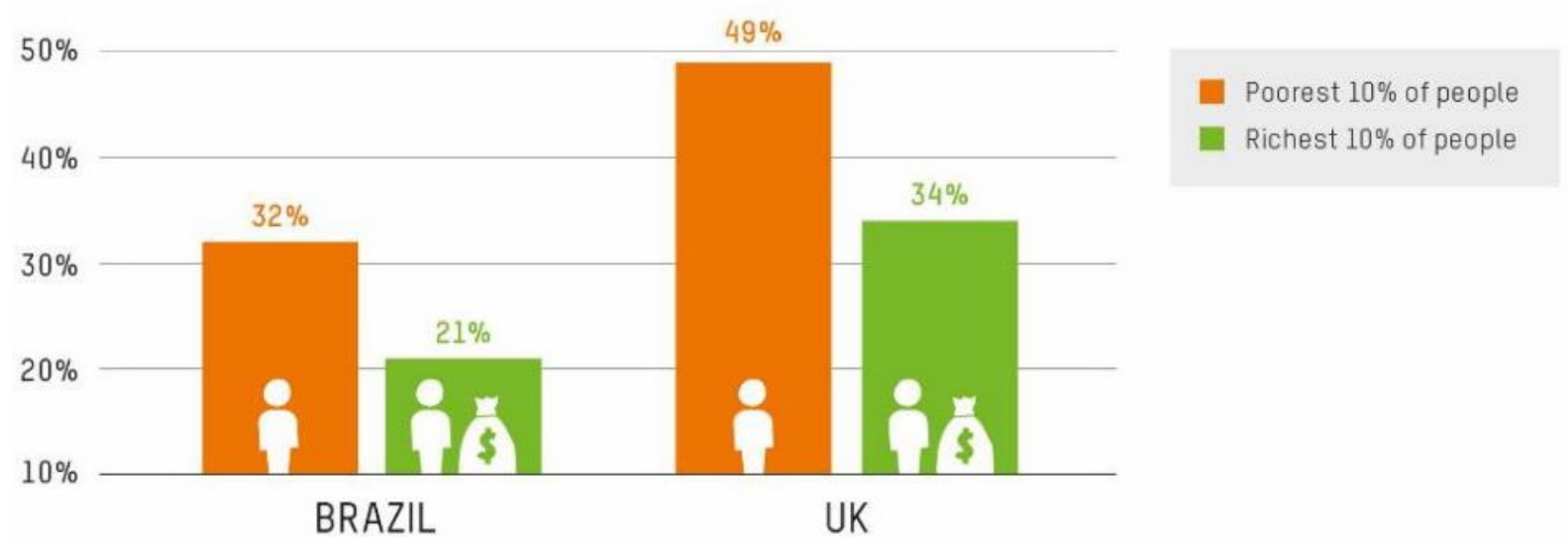

Brazil INESC. (2015). and UK Office for National Statistics. (2018). ${ }^{116}$

The situation is compounded by industrial levels of tax dodging by the super-rich and corporations. The super-rich are hiding at least $\$ 7.6$ trillion from the tax authorities, avoiding an estimated \$200bn in tax revenues. ${ }^{118}$ While millions of refugees are refused a safe haven, the richest can buy citizenship in any one of a number of countries offering minimal taxes and scrutiny of their wealth. ${ }^{119}$ For Africa alone, as much as $30 \%$ of private wealth may be held offshore, denying African governments an estimated $\$ 15 \mathrm{bn}$ in tax revenues. ${ }^{120}$ With armies of tax advisers, multinational companies exploit loopholes in tax codes to shift profits to tax havens and to avoid taxes, costing developing countries an additional estimated $\$ 100$ bn of lost corporate income tax. ${ }^{121}$

The IMF has shown that there is significant potential to raise more revenue from the richest individuals and corporations. ${ }^{122}$ Contrary to common belief, this will not harm the economy, ${ }^{123}$ and indeed there is growing evidence that failure to redistribute is causing economic harm. ${ }^{124}$ For example, Colombia raises $10 \%$ of its tax from taxing wealth. ${ }^{125}$ It introduced a wealth tax in 2015 on all those with wealth over one billion Colombian pesos, or $\$ 315,000 .{ }^{126}$
'I'll probably be the lowest paying taxpayer in the office.'

- Billionaire Warren Buffet points out that he pays a lower effective rate of tax than the rest of the employees in his office, including his secretary. ${ }^{117}$ 
Figure 4: Declining taxation of rich individuals and corporations

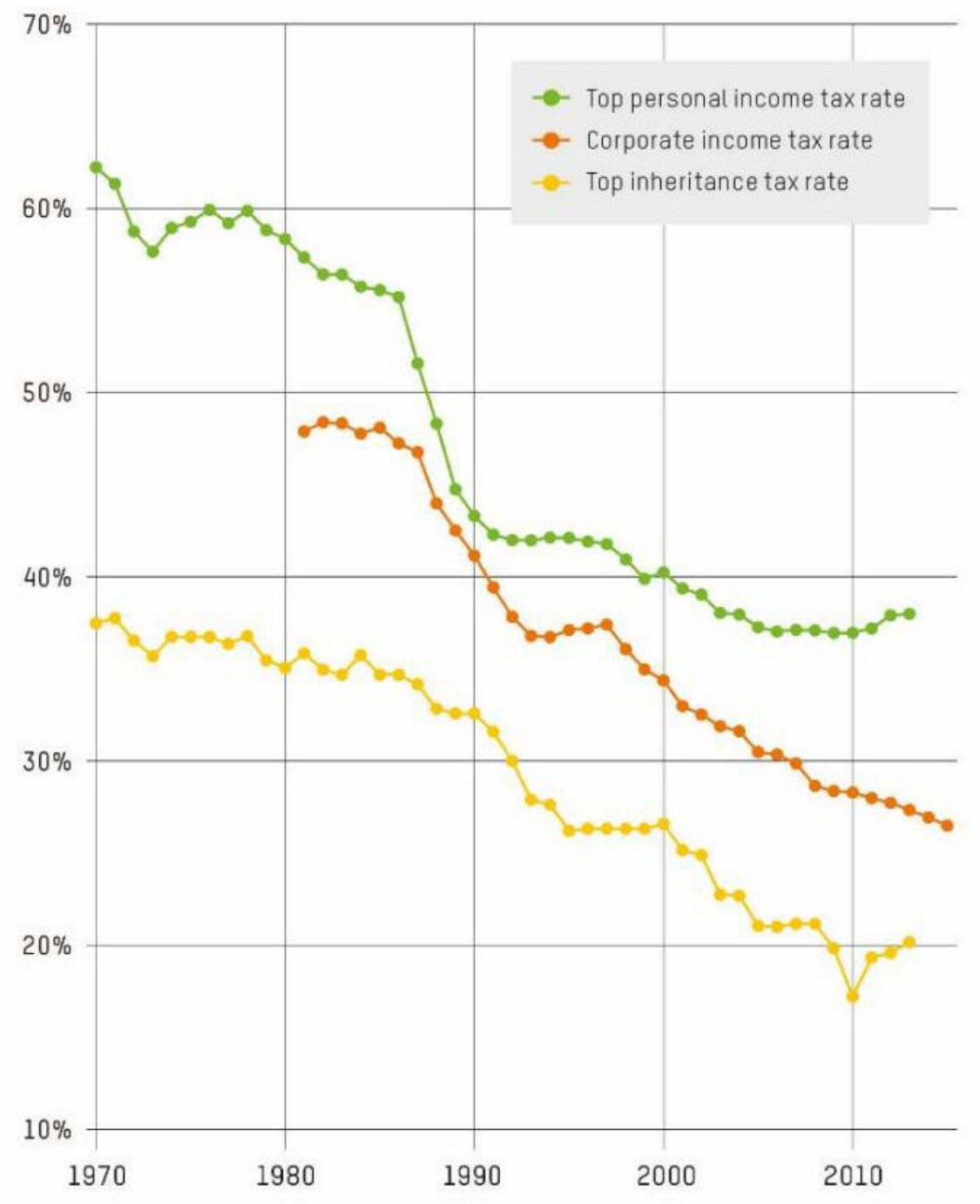

Sources: Scheve and Stasavage $(2016)^{127}$ for personal income tax and inheritance tax and Tax Foundation for corporate income tax. ${ }^{128}$ Note: Sample of 20 rich countries.

Tax policies have the potential not only to reduce the gap between rich and poor, but also to decrease inequality between women and men. However, the current global tax system, through relying more on taxes like VAT, is shifting the burden to the poorest individuals and households, meaning the majority of those affected are women. This is no coincidence, as it is the poorest women who have least influence over tax decisions and least opportunity to hold government to account.

Without addressing this problem of under-taxation of those most able to pay, the inequality crisis will remain out of control and we will not be able to overcome poverty. 


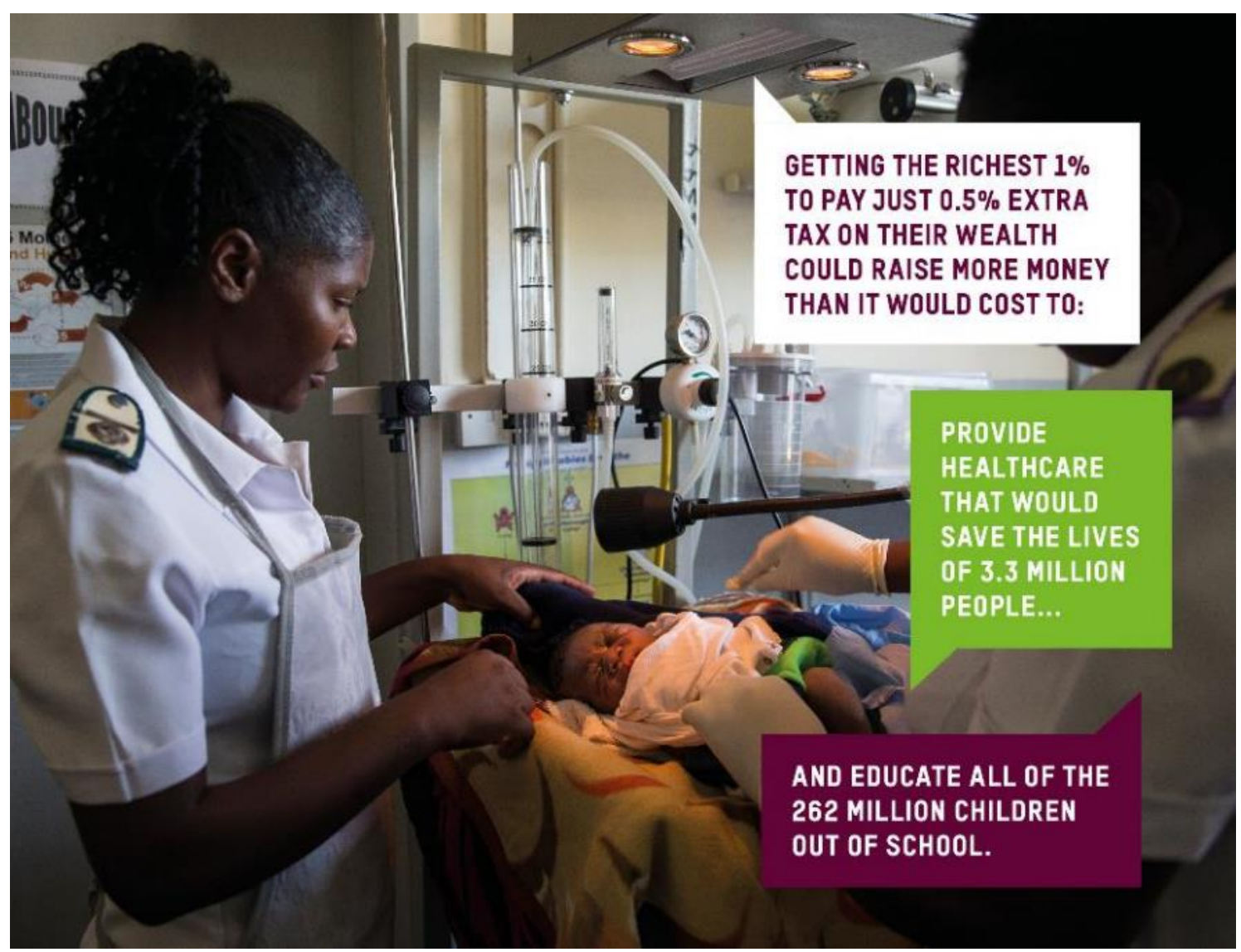

Source: Methodology Note. ${ }^{129}$ Photo: Nurse Margaret Nyagwaya, left, takes care of a baby a few minutes after his birth at the maternity ward at Zvamabande hospital in the Shurugwi district of Zimbabwe. She says: 'Women like to come to the clinic and give birth here, they get extra vitamins to get stronger and we take good care of them.' The hospital was supported by partner NGOs during the Zimbabwe Joint Humanitarian Response to the 2015-2016 El Niño crisis. Photo: Ilvy Njiokiktjien/Oxfam Novib.

\section{CHOOSE THE PUBLIC GOOD, NOT PRIVATE WEALTH}

Today's levels of inequality and poverty are a choice. We can continue to choose to reward those who are already rich, or we can choose to fight inequality and end poverty. Or we can choose to build a Human Economy instead, where the richest people and corporations pay their fair share of tax, and use those valuable resources to fund public services and social protection for all. We could free billions of people from a life of poverty. Free them from the fear of the cost of falling sick. Allow every child to fulfil their potential and use their talents. This could be a massive step towards equality between women and men, and create safer, more equal and happier societies for our children and grandchildren. The choice is ours.

Governments should listen to ordinary citizens and take meaningful action to reduce inequality. All governments should set concrete, timebound targets and action plans to reduce inequality as part of their commitments under Sustainable Development Goal (SDG) 10 on inequality.

'The true measure of any society can be found in how it treats its most vulnerable members.' - Mahatma Gandhi. 
These plans should include action in the following three areas:

1. Deliver universal free health care, education and other public services that also work for women and girls. Stop supporting privatization of public services. Provide pensions, child benefits and other social protection for all. Design all services to ensure they also deliver for women and girls.

2. Free up women's time by easing the millions of unpaid hours they spend every day caring for their families and homes. Let those who do this essential work have a say in budget decisions and make freeing up women's time a key objective of government spending. Invest in public services including water, electricity and childcare that reduce the time needed to do this unpaid work. Design all public services in a way that works for those with little time to spare.

3. End the under-taxation of rich individuals and corporations. Tax wealth and capital at fairer levels. Stop the race to the bottom on personal income and corporate taxes. Eliminate tax avoidance and evasion by corporates and the super-rich. Agree a new set of global rules and institutions to fundamentally redesign the tax system to make it fair, with developing countries having an equal seat at the table. 


\section{INEQUALITY IS OUT OF CONTROL}

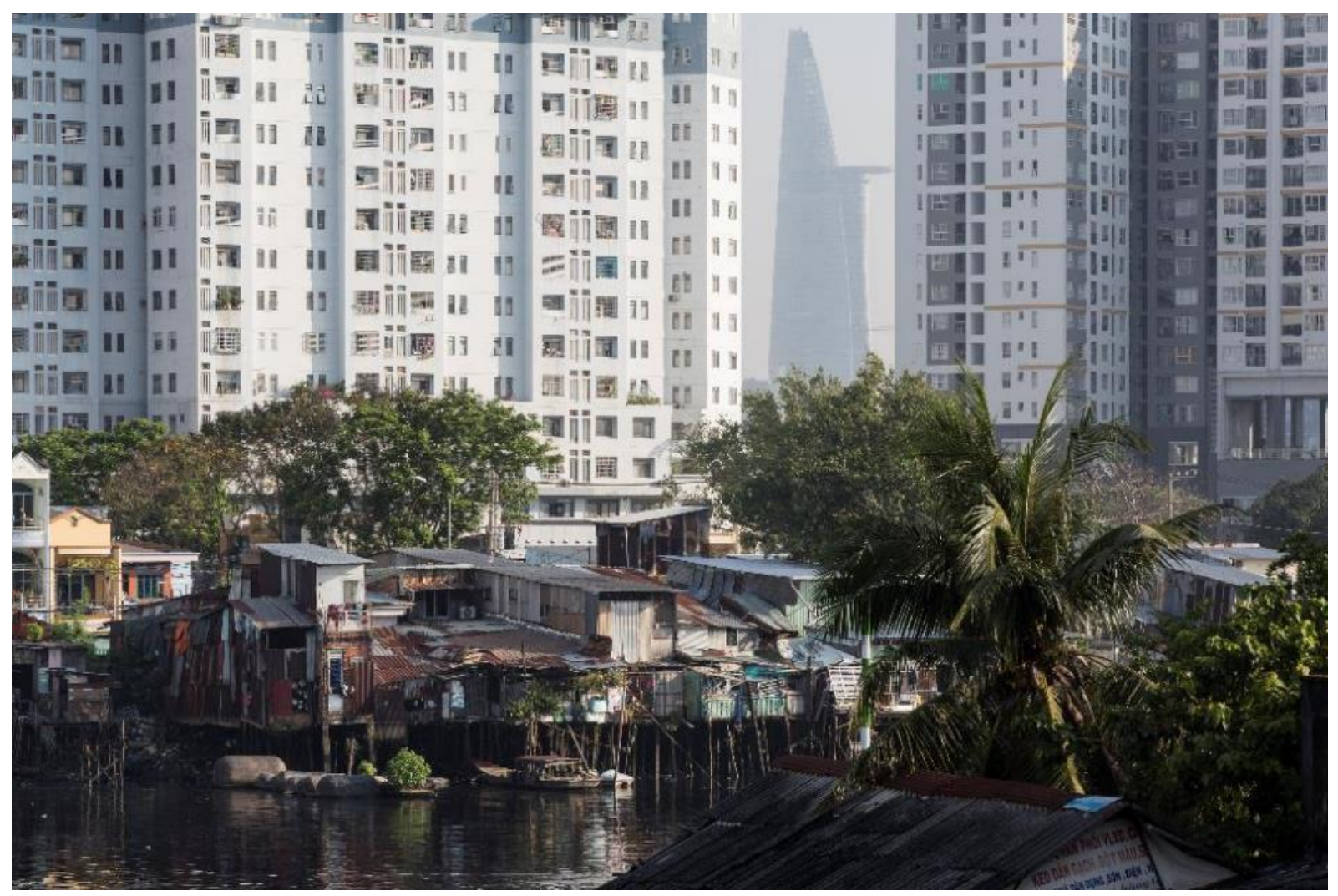

The Bitexco Financial Tower, framed by high-rise flats and a poor neighbourhood along the Saigon River in Ho Chi Minh, Vietnam. Photo: Eleanor Farmer/Oxfam.

- The wealth of the world's richest has continued to grow rapidly in the last year.

- The rate at which extreme poverty is reducing has halved, and it is increasing in sub-Saharan Africa.

- Inequality between rich and poor translates into inequality in education and health - poor people have far fewer educational opportunities and live much shorter lives.

\section{OUR LEADERS ARE FAILING TO TACKLE THE GROWING GAP BETWEEN RICH AND POOR}

The majority of our political leaders are failing to fight inequality. ${ }^{130}$ While many are paying lip service to the need to address the problem, very few are actually taking steps to curb the crisis. For example, despite professing to be on the side of 'ordinary Americans', the government of US President Donald Trump has given huge tax cuts to the richest people and corporations. ${ }^{131}$

'Hapa Kenya kuna kabila mbili, maskini na matajiri (In Kenya there are only two tribes, the poor and the rich).'

- Nyambura Maruga, activist, Kenya Fight Inequality Alliance 
This is not true for every government. Oxfam and Development Finance International's Commitment to Reducing Inequality (CRI) index 2018 highlights some governments that are taking steps to reduce inequality. ${ }^{132}$ For example:

- South Korea's government has increased the minimum wage, raised taxes on the richest people and corporations, and introduced universal child support. ${ }^{133}$

- Indonesia's government has increased the minimum wage and boosted spending on health. ${ }^{134}$

- Sierra Leone's government has made primary and secondary education free and is increasing tax collection from the richest. ${ }^{135}$

Extreme inequality is not inevitable; it is a policy choice. ${ }^{136}$ Such positive steps by some governments highlight the failure of many of our political leaders to do the right thing. It is possible to build a more Human Economy- one that is more equal and values what truly matters.

At the same time, people are demanding change, and political leaders need to start representing the interests of ordinary citizens. In 2017, Oxfam polled 70,000 people across 10 countries representing a quarter of the world's population. Nearly two-thirds thought the gap between rich and poor needs to be addressed urgently. ${ }^{137}$

\section{ANOTHER BUMPER YEAR FOR BILLIONAIRES}

It is 10 years since the financial crisis that shook our world and caused enormous suffering. In that time, the fortunes of the richest have risen dramatically:

- In the 10 years since the financial crisis, the number of billionaires has nearly doubled. ${ }^{138}$

- The wealth of the world's billionaires increased by $\$ 900 \mathrm{bn}$ in the last year alone, or $\$ 2.5 \mathrm{bn}$ a day. Meanwhile the wealth of the poorest half of humanity, 3.8 billion people fell by $11 \%$. ${ }^{139}$

- Billionaires now have more wealth than ever before. Between 2017 and 2018, a new billionaire was created every two days. ${ }^{140}$

- Wealth is becoming even more concentrated - last year, 26 people owned the same as the 3.8 billion people who make up the poorest half of humanity, down from 43 people the year before. ${ }^{141}$

- The world's richest man, Jeff Bezos, owner of Amazon, saw his fortune increase to $\$ 112 \mathrm{bn}$. Just $1 \%$ of his fortune is the equivalent to the whole health budget for Ethiopia, a country of 105 million people. ${ }^{142}$

- If all the unpaid care work done by women across the globe was carried out by a single company, it would have an annual turnover of $\$ 10$ trillion - 43 times that of Apple. ${ }^{143}$ 
In many countries, the super-rich live behind security guards and electric fences in their own world. They use helicopters to avoid traffic jams and poorly maintained roads. ${ }^{144}$ Their children go to the most expensive schools, often abroad. ${ }^{145}$ They have access to world-class health services. While millions of refugees are refused a safe haven, the richest can buy citizenship in any one of a number of countries offering minimal taxes and scrutiny of their wealth. ${ }^{146}$

\section{Not paying their fair share of tax}

One key way governments can tackle the extreme concentration of wealth is through taxation. ${ }^{147}$ Yet instead, the richest individuals and corporations are systematically and structurally undertaxed. In some countries, they are paying rates of tax that are among the lowest in a century. ${ }^{148}$ As most of their wealth is in financial assets such as shares, ${ }^{149}$ the super-rich are often the main beneficiaries of lower corporate tax bills as well as lower personal ones. ${ }^{150}$

At the same time, the super-rich are hiding at least $\$ 7.6$ trillion from tax authorities and dodging an estimated $\$ 200 \mathrm{bn}$ in annual tax revenues. ${ }^{151}$ Recent leaks in the EU show the lengths to which some super-rich people will go to avoid tax, ${ }^{152}$ as did revelations in The New York Times that President Trump's fortune was allegedly built on a foundation of tax dodging. ${ }^{153}$ Many are buying citizenship in other countries with minimal tax rates to cut their tax bills. ${ }^{154}$ In Latin America, for example, the effective tax rate for the top $10 \%$ of earners is just $4.8 \%{ }^{155}$

The push for lower taxation of those at the top has its roots in the idea that if the rich become richer, all of society will benefit. ${ }^{156}$ However, this 'trickle-down' orthodoxy has been increasingly questioned. In the face of growing inequality, even the International Monetary Fund (IMF) and the UK's The Economist magazine are saying that there is ample scope to tax the richest more without hurting economic development, ${ }^{157}$ and that such redistribution is required to tackle inequality. ${ }^{158}$

A core argument of this paper, outlined in section 4, is that this trend must be reversed, and that it is common sense that the richest individuals and corporations pay their fair share of tax to fund health, education and other public services for all. Governments can use progressive taxation and spending to dramatically reduce the gap between rich and poor and between women and men. ${ }^{159}$ If they fail to do this, the inequality crisis will remain out of control.

\section{A POOR YEAR FOR POVERTY REDUCTION}

\section{Poverty reduction slows}

The good news is that globally the number of people living in extreme poverty (defined by the World Bank as less than $\$ 1.90$ a day) has
'Taxing the rich is not a matter of choice. It is a matter of the lives of the poor. If the rich are not going to pay their fair share of tax, the poorest will pay the highest price'. - Shahzad Khan and Channan Development Associates (CDA) Pakistan 
continued to fall, from 1.9 billion in 1990 to 736 million in $2015 .{ }^{160}$ This is testament to the tremendous progress of recent decades. However, the pace of poverty reduction has halved since 2013, and the number of people living in extreme poverty in sub-Saharan Africa has been increasing. ${ }^{161}$

Billions of people live just above the extreme poverty line and are only one medical bill or failed harvest away from destitution. ${ }^{162}$ The World Bank finds that women are more often among the poorest people, particularly during their reproductive years, because of the level of unpaid care work they are expected to do. ${ }^{163}$

While the extreme poverty threshold is politically important for mobilizing action, $\$ 1.90$ is too low a figure to define extreme poverty in many countries, i.e. it does not represent the estimated minimum level of income required to secure the necessities of life. ${ }^{164}$ The World Bank has responded to this by introducing poverty lines of $\$ 3.20$ and $\$ 5.50$ for lower and upper middle-income countries, respectively. The Bank concludes that gains against extreme poverty have not been matched by reductions in the number of people living below these new measures of poverty. Almost half of the world's population -3.4 billion people - live on less than $\$ 5.50$ a day. ${ }^{165}$

\footnotetext{
NEARLY HALF

THE WORLD'S POPULATION

(3.4 BILLION PEOPLE)

IS LIVING ON LESS THAN
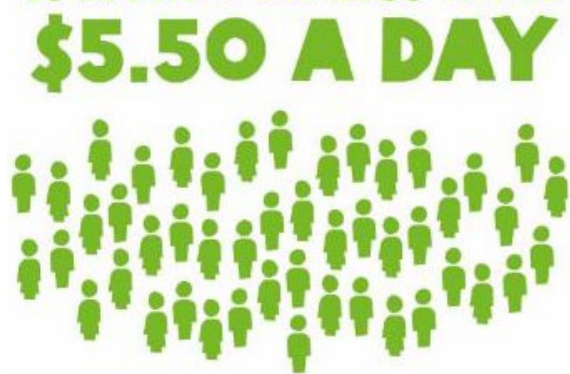

WHILE THERE ARE

MORE BILLIONAIRES THAN

EVER BEFORE $[2,208)$

Source: World Bank (2018a) ${ }^{166}$ and methodology note. ${ }^{167}$

And as increasing amounts of income and wealth go to those at the very top, it is not just the poorest people who are losing out, but the middle classes too. In rich countries, they are often seeing their incomes stagnate. ${ }^{168}$

A core reason for this is inequality. The World Inequality Report 2018 showed that between 1980 and 2016, the poorest $50 \%$ of people only received 12 cents in every dollar of global income growth. By contrast, the richest $1 \%$ received 27 cents of every dollar. ${ }^{169}$ If we are to beat poverty, we must fight inequality. ${ }^{170}$
}

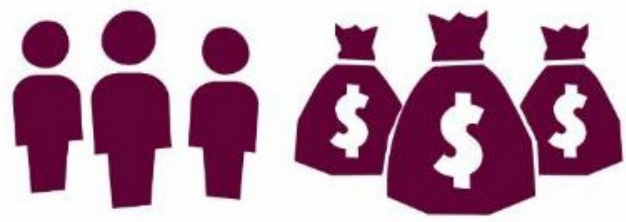

THEIR WEALTH INCREASING BY \$2.5BN A DAY 


\section{Wealth inequality and the gap between women and men}

Most of the world's richest people are men. ${ }^{171}$ Globally, women earn 23\% less than men. ${ }^{172}$ This gender pay gap is raising serious concern worldwide.

Less understood but equally alarming is the gender wealth gap, which along with earnings includes assets, savings and investments. Credit Suisse has this year estimated women's share of global wealth at $40 \%,{ }^{173}$ but with very significant differences regionally and for different groups of women. For example:

- In Africa and in countries like India, Pakistan and Bangladesh, women account for somewhere between $20-30 \%$ of wealth. ${ }^{174}$

- In the US, unmarried white men own 100 times more wealth than unmarried Hispanic women. ${ }^{175}$

Land is a vital source of wealth in many countries, yet it is one denied to many women. ${ }^{176}$ Women own as little as $11 \%$ of land in Brazil; ${ }^{177}$ in Bangladesh, the proportion of men that own land is six times that of women. ${ }^{178}$
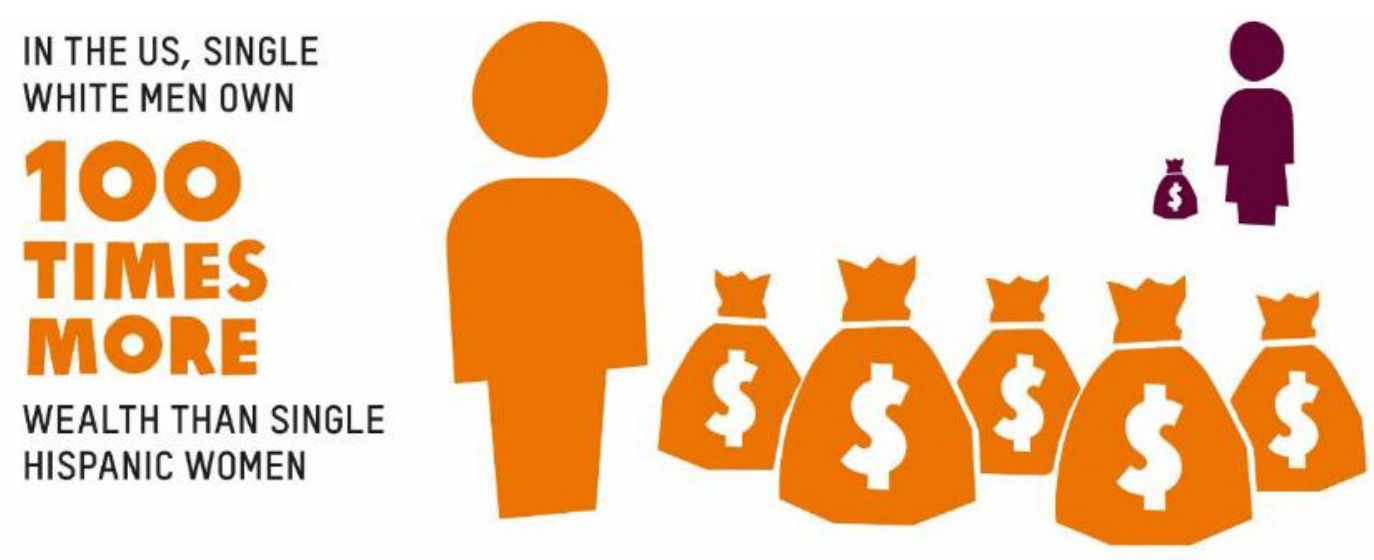

Source: M. Chang. (2015). ${ }^{179}$

Having less wealth means that women have fewer resources to cope with family crises such as ill health - especially given that they have disproportionate care responsibility for young, sick and elderly family members. Women have less bargaining power and are more likely to live in poverty in older age. ${ }^{180}$

Gender wealth gaps are caused by the cumulative effect of a range of structural inequalities. Women and girls have more unpaid care work than men and boys owing to restrictive social attitudes that consider care to be 'women's work', and limited access to quality public services that could reduce their care workload. As a result, over their lifetimes women have less opportunity then men to engage in paid work, they earn less and are less able to invest in assets. When women are engaged in paid work, it is often precarious or poorly paid. ${ }^{181}$ Women almost always have less access to and control over productive assets (such as land, credit, insurance and skills). ${ }^{182}$ 
Societies in which the gap between rich and poor is much lower are those in which women are treated more as equals. ${ }^{183}$ Therefore, ensuring equal rights to inheritance and asset ownership, decent jobs for women, greater representation of women in leadership positions, and challenging barriers to women's wealth accumulation (such as harmful social attitudes and poor public services) are important steps to close the gender wealth gap and create fairer societies for all.

\section{WHY DOES THE GAP BETWEEN RICH AND POOR MATTER?}

The continued accumulation of wealth by the very richest in our societies, while most of humanity subsists on barely anything, is extremely detrimental.

Inequality makes the fight to end poverty much harder. Unless growth benefits the poorest people more between now and 2030, the World Bank forecasts that the first Sustainable Development Goal (SDG) - to eliminate extreme poverty - will be missed. ${ }^{184}$

Inequality is destabilizing. For instance, in recent years we have seen a rise in authoritarianism by governments worldwide, with crackdowns on freedom of speech and democracy. We have also seen a rise in popularity for right-wing, racist, sexist views and authoritarian politicians who support them. Many have pointed to the link between this global trend and high levels of inequality. ${ }^{185}$

Inequality undermines our societies. It is bad for everyone, not just the poorest people. In more unequal countries, trust ${ }^{186}$ is lower and crime higher. ${ }^{187}$ Unequal societies are more stressed, less happy and have poorer mental health. ${ }^{188}$

Inequality makes the fight to save our planet from climate breakdown even harder. Oxfam has shown that the average carbon footprint of the richest $1 \%$ globally could be as much as 175 times higher than that of the bottom $10 \%{ }^{189}$ To get us to a situation where everyone on earth is living on more than $\$ 5$ a day with current levels of inequality would require the global economy to be 175 times bigger than it is today, which would destroy our planet. ${ }^{190}$ The only way we can beat poverty while saving our planet is to tackle inequality.

Inequality also has profound implications for the future of our children and the opportunities they will have to live a better life. And perhaps the most powerful, uncomfortable and undeniable outcome of inequality is its impact on how long we can expect to live.

\section{Talent is everywhere, opportunity isn't}

The opportunity for every child to learn and to make the most of their talents is at the heart of a fairer society. Education is core to social mobility, which in turn is central to fighting inequality, reducing poverty 
and growing economies. ${ }^{191}$ Unfortunately, the World Bank has found that social mobility is not improving in much of the world. Half of people born in an average developing economy in the 1980s have received more education than their parents; this proportion has not changed since the 1960 s. ${ }^{192}$ Only $12 \%$ of adults born in the 1980 s in sub-Saharan Africa have received more education than their parents. ${ }^{193}$

Oxfam's research on social mobility in Vietnam found that mobility between generations has slowed in recent years. ${ }^{194}$ In Latin America, intergenerational mobility is very low because the quality of education differs greatly between social classes. ${ }^{195}$ Gender inequality interacts with economic inequality to lower the social mobility of women and girls in particular. In Mexico, girls born in the poorest $20 \%$ of the population have twice the probability of remaining poor than their male counterparts. They have just a quarter of the chance of an equally poor boy to become one of the richest $20 \%$ of the population. ${ }^{196}$ In Kenya, a girl from a poor family has a one in 250 chance of pursuing her studies beyond secondary school, compared to a one in three chance for a boy from a rich family. ${ }^{197}$ On average in Kenya, a child from a rich family will have double the amount of education compared to a child from a poor family. ${ }^{198}$

Every child has the right to an education. Yet as section 3 shows, in many places a good education is often available only to children from rich families. They can be sent to expensive private schools, while children from poor families attend underfunded and under-resourced public schools. Further privatization of schooling is being promoted by the World Bank and others, despite evidence that it increases inequality. ${ }^{199}$ This is failing these individual children, who have as much right to goodquality education as children from rich families. It is also failing society, as a generation of talented poor girls and boys cannot fulfil their promise and contribute fully to human progress. Brilliant doctors, teachers or entrepreneurs are instead herding goats or collecting water. Humanity faces unprecedented challenges. Yet instead of mobilizing the talents of all of people, inequality means we are squandering this potential.

\section{Buying a longer life}

Across the world, it is the poorest children who are most likely to die. The average number of children dying before they are five has decreased in almost every country in recent years, which is a great achievement. But looking behind the averages, the gap between rich and poor is still unacceptable. A child from a poor family in Nepal is three times more likely to die before their fifth birthday than a child from a rich family. ${ }^{200}$ Economic inequality in turn interacts with other inequalities, such as race. In the US, a black child is twice as likely to die in their first year than a white child. ${ }^{201}$ In fact, black children in the US are more likely to die before their first birthday than children in Libya. ${ }^{202}$

Inequality is not just bad for the health of the poorest people. It is bad for all of society. Data from 103 developing countries shows that inequality is associated with higher death rates for the whole of society, rich and poor. ${ }^{203}$ 
Nevertheless, poorer people, and especially women and girls, feel the effects of inequality far more than others. People from rich families can access high-end private health services that are unavailable to the poorest families, who are left to cope with underfunded public clinics, less-qualified doctors and unregulated pharmacies. ${ }^{204}$ In countries across the world, being rich is a passport to better health and a longer life, while all too often being poor means more sickness and an earlier grave.

This is reflected in life expectancy figures, where wealth translates to many more years of life. In India, a woman from the so-called lowest caste can expect to live almost 15 years less than a high-caste woman. ${ }^{205}$

Life expectancy in one of the poorest parts of London is six years less than it is in one of the capital's richest neighbourhoods, just a few miles away. ${ }^{206}$ Life expectancy in Pinheiros, one of the richest parts of Sao Paulo, Brazil, is 79 years. In one of the poorest suburbs, Cidade Tiradentes, it is 54 years. ${ }^{207}$

\section{LIFE EXPECTANCY IN THE RICHEST PARTS OF SÃO PAULO, BRAZIL, IS 79 YEARS}

IN ONE OF THE POOREST AREAS OF THE CITY IT IS 54 YEARS
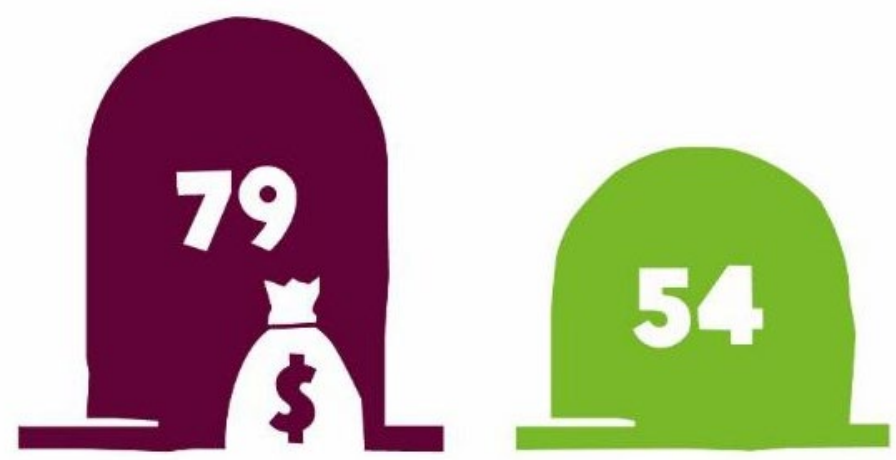

It is hard to think of a greater injustice than living 25 years less, simply because you are poor.

To change this, and to fight inequality, we need to radically rethink what we value in our economies. In our previous papers, Oxfam has introduced the concept of a Human Economy ${ }^{208}$ - an economy that rejects the broken economics of recent decades and instead designs a fairer, more inclusive and sustainable world. A key part of a Human Economy is a state that taxes fairly and provides universal public services for all. This is the focus of this report.

'My father passed away and I dropped out of school. He was sick and died. I was doing well in school but my mother wasn't able to help me continue my education. I wanted to become a journalist; to expose crime, and problems in a girl child's education. Now I work as a cleaner but I still dream of being a journalist.'

- Matilda, Ghana 


\section{ECONOMIC INEQUALITY AND GENDER INEQUALITY}

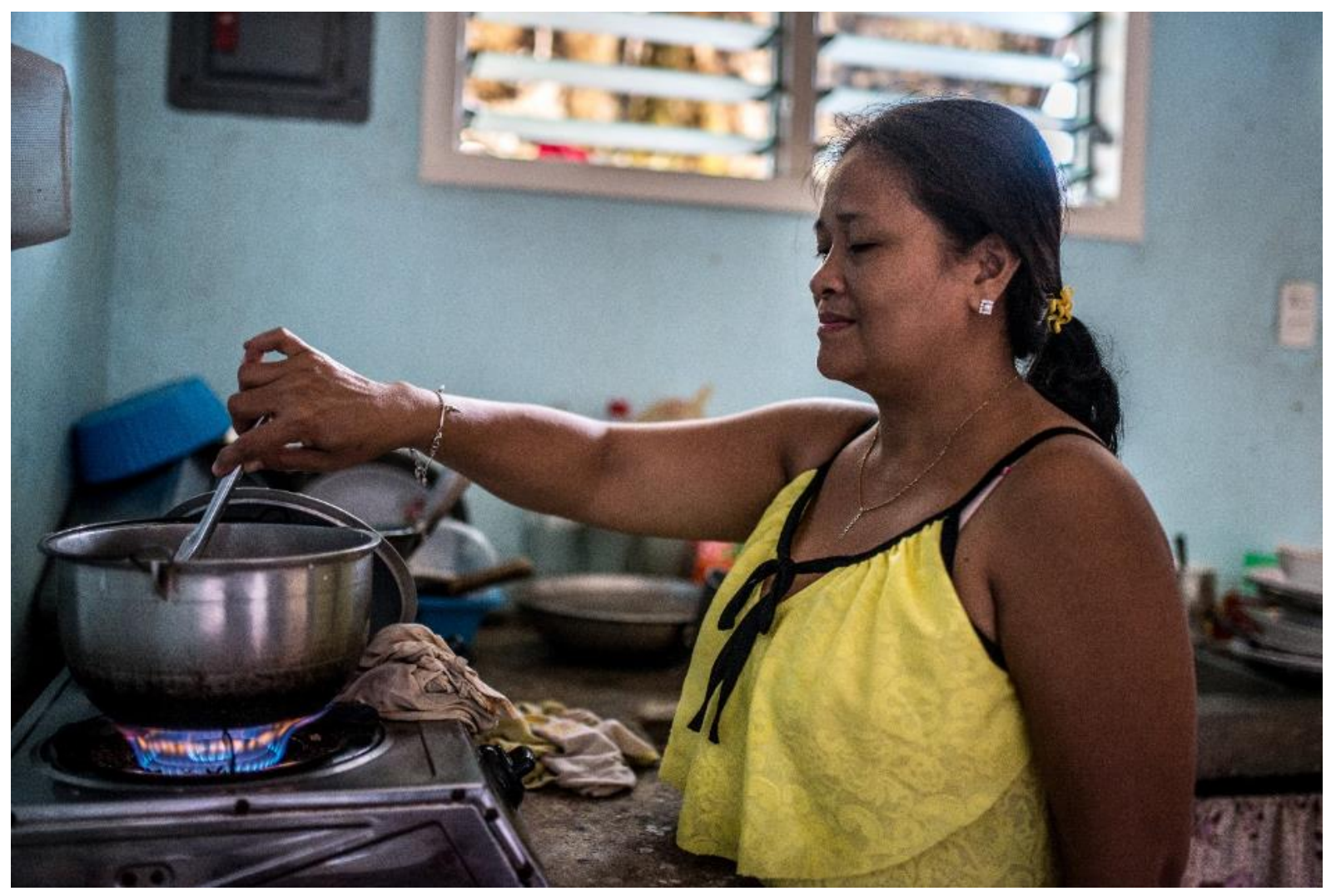

Elizabeth Gabrinao cooks rice in her kitchen in the GMA Resettlement Area, Tacloban, the Philippines, where her family relocated after Typhoon Haiyan devastated their home in 2013. One day is not enough for all the care work Elizabeth does, and feeding her family is a struggle on her husband's small salary. Photo: Aurelie Marrier d'Unienville/Oxfam.

- Economically more equal societies are also societies where women and men are more equal.

- Government economic decisions, especially on taxation on spending have a big impact on gender inequality

- The unpaid time women spend cooking, cleaning and caring has to be addressed urgently

Closing the gap between rich and poor is impossible without ensuring equality between women and men. Economically more equal societies cannot be built on a foundation of oppressing half of humanity.

Societies where the gap between rich and poor is much lower are societies where women are treated more as equals. ${ }^{209}$ Involving women on an equal footing to men in the economy helps build more equal and resilient economies. ${ }^{210}$ However, as outlined in section 1, the economic inequality crisis is continuing, concentrating wealth with the very few the vast majority of whom are white men. An economic model that fails to raise public revenue progressively and does not invest in public services 
is not compatible with equality between women and men, and will most disadvantage women living in poverty. ${ }^{211}$

Economic policies, and specifically the way that governments raise and spend money, can play a key role in changing this. In a Human

Economy, women and men would have the same opportunities and access to resources and would be compensated equally. Everyone would receive the care they need, and the work that is done to care for others - paid or unpaid - would be valued and considered an equal responsibility between the state, women and men. When designing policies and deciding how to invest public resources, governments would prioritize closing gaps between rich and poor, women and men, and between racial and ethnic groups.

In this section, we look at the links between economic and gender inequality. In particular, we will focus on inequalities in the time spent working in the home caring for children, partners and older people, and what government spending can do to address this.

\section{ECONOMIC POLICIES AND THEIR IMPACT ON WOMEN AND MEN}

A government's economic decisions can have very different impacts on women and men. These can be positive: policies like increased minimum wages, or free healthcare and investments in water infrastructure can benefit poor women the most. However, all too often policies widen the gap between women and men.

Nowhere is this more apparent than in the impacts of austerity. Women are especially affected because embedded sexist social attitudes mean that they tend to have greater responsibility for unpaid care, earn less, own less and are more likely to be living in poverty. When a crisis hits, women are the economic shock absorbers - filling the gaps when services are cut, at considerable personal cost. As a result of austerity policies in Mexico and Argentina since the 1990s, women from poorer households with low levels of education and high unpaid care responsibilities were forced to take up poorly paid and precarious work to survive. ${ }^{212} \mathrm{~A}$ study on the effects of austerity in Europe following the 2008 financial crash found that it reduced public spending on caresupporting services and social protection measures such as paternity leave, the costs of which have been largely picked up by women. For example, Portugal closed a number of public kindergartens and Romania, Macedonia and Slovenia all reduced maternity or parental leave benefits. ${ }^{213}$

Globally, teachers and health workers tend to be the majority of public sector workers, ${ }^{214}$ and women predominate in these professions. ${ }^{215}$ This means that cuts to public services often impact women the most. Women and children, particularly those from black and minority ethnic groups and poor households, disproportionately rely on welfare benefits like child 
support grants because of their lower incomes and care responsibilities, so any reductions in these hurt women more.

\section{Public spending and women}

Public spending is a powerful tool that governments can use to close the gap between women and men. Research has shown how good-quality universal public services and infrastructure, especially in areas such as health, education and water - as well as social protections like pensions and child support grants - can have multiplier effects on reducing gender inequalities. ${ }^{216}$ Public services can be designed in ways that recognize the different needs of women and men, while challenging the social stereotypes that assume that women should be responsible for more care work than men. They can seek to transform gender relations rather than accept them, for example ensuring that education empowers girls to challenge the status quo.

Conversely, underfunded and low-quality public services that are blind to the needs of women and girls can increase the gender gap. Instead of challenging outdated social attitudes about the roles of women, they can reinforce them. The role that public services can play in promoting equality between men and women is addressed in more depth in section 3.

\section{Taxes and women}

Taxation policy can also have a different impact on women and on men because of differences in their economic positions, caring responsibilities and decision-making power. Cuts to wealth taxes, taxes on top incomes and corporate taxes disproportionately benefit men, as they are the top earners and the primary owners of wealth. Conversely, increases in taxes like value-added tax (VAT), which have a disproportionate impact on poorer people, impact women most as they are often poorer. ${ }^{217}$

Well-designed tax systems can instead challenge gender inequality and promote greater equality between women and men. The relationship between taxation and gender inequality is addressed in more depth in section 4 .

\section{UNPAID CARE AND INEQUALITY}

Our economies are built on hundreds of millions of hours of free labour: caring for children, the elderly and the sick; washing, cleaning, cooking, and fetching water and firewood. The clear majority of this free labour is provided by women and girls - a result of unfair social attitudes that make it their responsibility. If all the unpaid care work done by women across the globe was carried out by a single company, it would have an annual turnover of $\$ 10$ trillion $^{219}$ - 43 times that of Apple. ${ }^{220}$ Until we recognize this injustice and do something about it, neither economic nor gender equality is achievable.
'The problem with gender is that it prescribes how we should be rather than recognizing how we are.' - Chimamanda Ngozi Adichie in We Should All Be Feminists $^{218}$ 


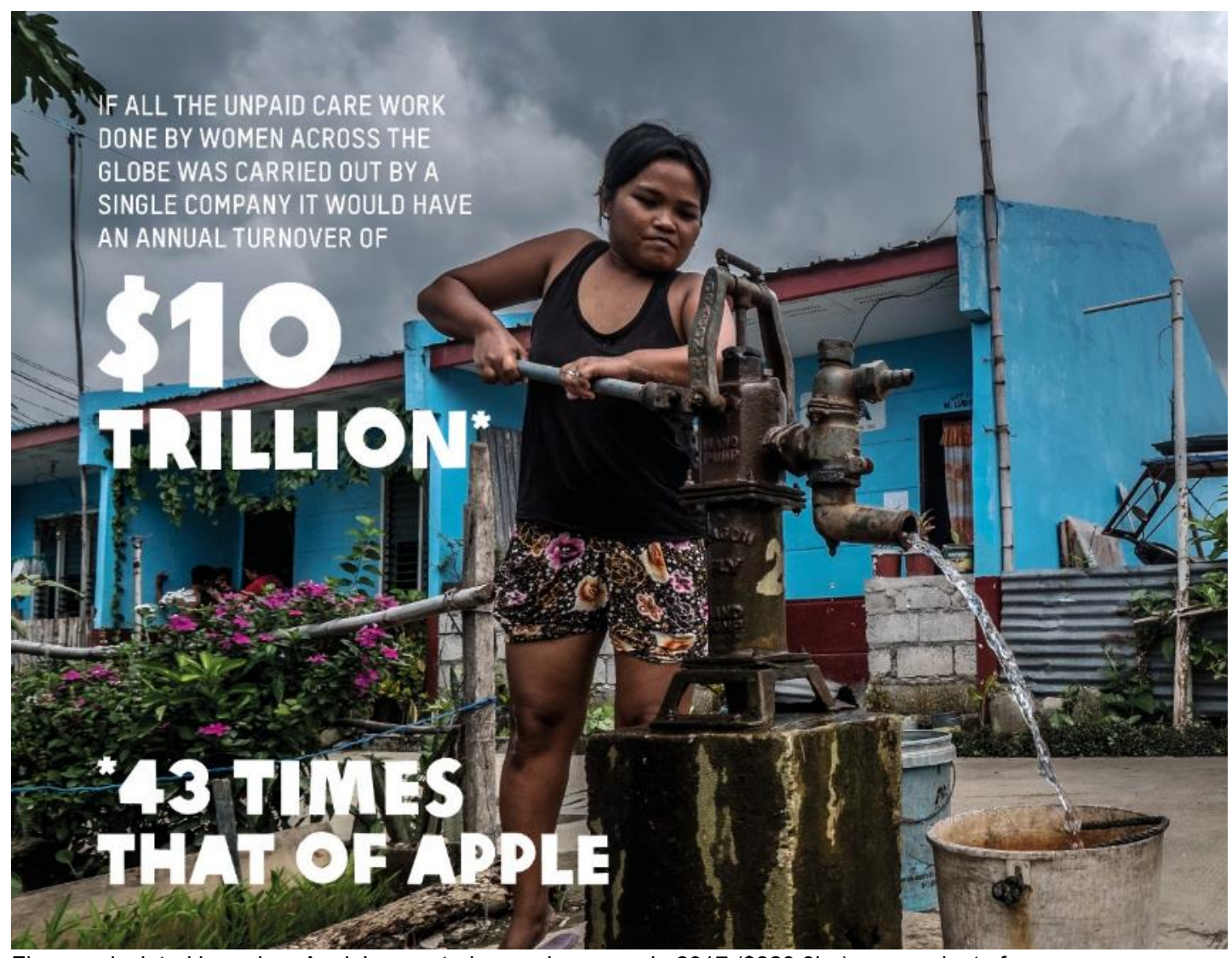

Figure calculated based on Apple's reported annual revenue in 2017 (\$229.3bn); see endnote for source. ${ }^{221}$ Photo: Rosalyn Martinez collects water from a water pump in the GMA Resettlement Area, North Tacloban, Philippines. The site was built to relocate families after Typhoon Haiyan, but many residents say they are in an even more vulnerable situation now and lack basic services such as reliable and clean water. Credit: Aurelie Marrier d'Unienville/Oxfam.

Oxfam research in rural communities in Colombia, the Philippines, Ethiopia, Uganda and Zimbabwe showed that women have an average 14 hours a day with some care responsibility. ${ }^{222}$ Another study found that poor rural women typically do five times more care work than men. ${ }^{223}$ This heavy, unpaid care workload leaves them disadvantaged in many ways:

- The long hours and stress adversely affect their health.

- It limits their ability to get decent paid work.

- It means they are less able to improve their skills and take up leadership positions.

- It undermines their ability to participate in politics and civic life, which in turn means that the needs of women are less likely to be addressed by politicians.

- Girls' education suffers when they are taken out of school to help in the home, while their brothers continue their studies.

- Although on average women do more unpaid care work than men, the situation is a lot worse for poor women. Poorer women are less likely to have access to piped clean water and public services for health and childcare. In Tunisia, three- and four-year-old children from the poorest families are six times less likely than those from the richest families to be in pre-school childcare. ${ }^{224}$ Poor families are less likely to own labour-saving devices like washing machines, or to be able to afford domestic workers. Domestic workers are themselves 
overwhelmingly poor women who have to juggle many hours of lowpaid domestic work with their own care work at home. Unpaid care work amplifies economic inequality, because those with the least wealth also have the least time to earn an income and accumulate wealth over their lifetimes.

Unpaid care is a huge hidden subsidy to the economy, which is ignored by standard economic analysis. If governments incorporated an analysis of unpaid care into their economic policies and took greater responsibility for meeting the care needs of their populations, it would go a long way towards tackling economic and gender inequality.

For example, in response to the excessive workloads of women and the need to end precarious and poorly paid caring jobs, in 2015 the Government of Uruguay established the National Integrated Care System. All children are entitled to the right to care, and the work of caregivers is recognized and valued with training and support programmes. ${ }^{225}$

Governments must confront outdated social attitudes that see women as the primary caregivers, and which are often reflected in sexist policies such as maternity rather than parental leave. They should also invest more money in relevant public services that can significantly reduce women's care workload, including domestic water and electricity supplies, childcare, elder care, healthcare and public transport.

\section{Unpaid care and public services}

In reality, for too many people these vital public services remain badly underfunded. In sub-Saharan Africa, $65 \%$ of the population still have no access to electricity, while $37 \%$ continue to lack access to an improved water source. ${ }^{226}$ Inadequate access to basic public services greatly increases the amount of time poor households spend on unpaid care tasks such as fetching water, collecting wood, and caring for the sick in the absence of good medical care near to their homes. Women's unpaid contribution to the health sector alone is estimated to be worth approximately $3 \%$ of GDP in low-income countries. ${ }^{227}$

\section{IN SUB-SAHARAN AFRICA, THE POPULATION IS STILL LACKING ACCESS TO BASIC PUBLIC SERVICES LIKE WATER AND ELECTRICITY}

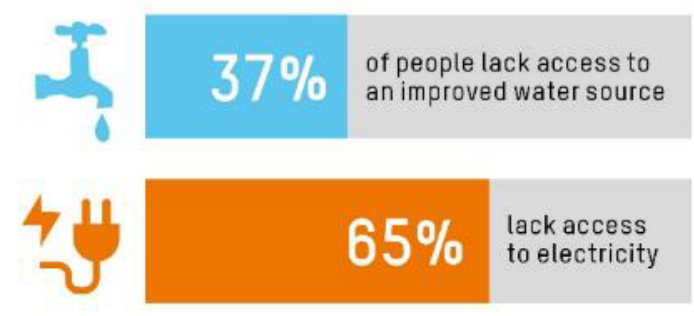

\section{THIS GREATLY INCREASES \\ THE AMOUNT OF TIME POOR HOUSEHOLDS SPEND ON UNPAID CARE TASKS}

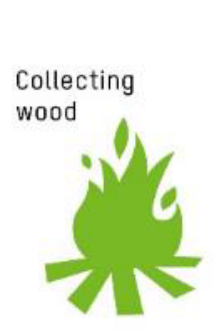

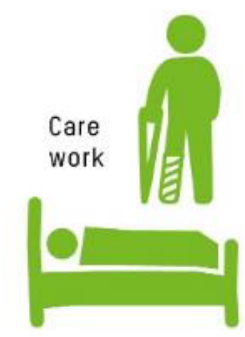

Conversely, investment in universal, free, care-supporting public services can bring about substantial improvements in poor women's lives. 
In parts of Zimbabwe, providing access to an improved water source could reduce women's average unpaid care workload by four hours a day ${ }^{228}$ - the equivalent of two months a year. Access to free public childcare in Rio de Janeiro, Brazil increased low-income mothers' employment rates by $27 \%$, and nearly doubled the employment of lowincome mothers who had previously not been in paid work. ${ }^{229}$

Rather than being a drain on government budgets, investments in such services deliver economic returns. Investing in care services creates jobs: recent research in six middle-income countries showed that investing $2 \%$ of GDP in strengthening health and care services could generate between 1-3\% growth in overall employment, with 24 million new jobs in China alone. This is $13 \%$ more jobs than if the same sum was invested in the construction industry. ${ }^{230}$ The cost to governments of such investments is comparatively low: a recent study in Turkey shows that investment in pre-school childcare and education has a higher return in terms of increased income tax and other revenues compared to an equivalent investment in the construction sector. ${ }^{231}$

More investment in public services is vital, but so is careful design and management to minimize the time it takes for women to access these services. Long travel and waiting times, restricted or unreliable opening hours, and the opportunity cost of lost income affect women more due to their considerable unpaid care responsibilities and greater time poverty. ${ }^{232}$ One study in rural Egypt showed that difficulty in paying for health services was reported by $42 \%$ of women as a barrier to access, while long distances and travel times were reported by $30 \%$ of women as a barrier to using health services. ${ }^{233}$ This illustrates the importance of investing in and building good free public clinics close to women's homes and places of work.

To make public services responsive to the needs of poor women, governments must provide genuine opportunities for poor women to have a say in key budget, design and management decisions.

Economic and gender inequality are closely intertwined, and the decisions that governments make over how to raise revenue and spend it can have either a powerful effect at reducing or increasing these inequalities. When governments make choices to cut taxes on the rich, or to cut services or make them available only to the privileged few, it denies opportunities to poor people, ignores the importance of care work to society, and leaves the poorest women and girls to fill in the gaps. It also concentrates excessive wealth in the hands of an elite, the majority of whom are men. The gendered nature of economic inequality reinforces inequality in all areas of women's lives, denying them the power to challenge systems of discrimination. This is not inevitable and women all over the world are mobilizing for and proposing alternatives. Instead, public services and taxation can be powerful tools to help governments tackle the interlinked challenges of gender inequality and economic inequality. The next two sections will explore how. the power of public services to close the gap. 


\section{HOW PUBLIC SERVICES AND SOCIAL PROTECTION CAN FIGHT INEQUALITY}

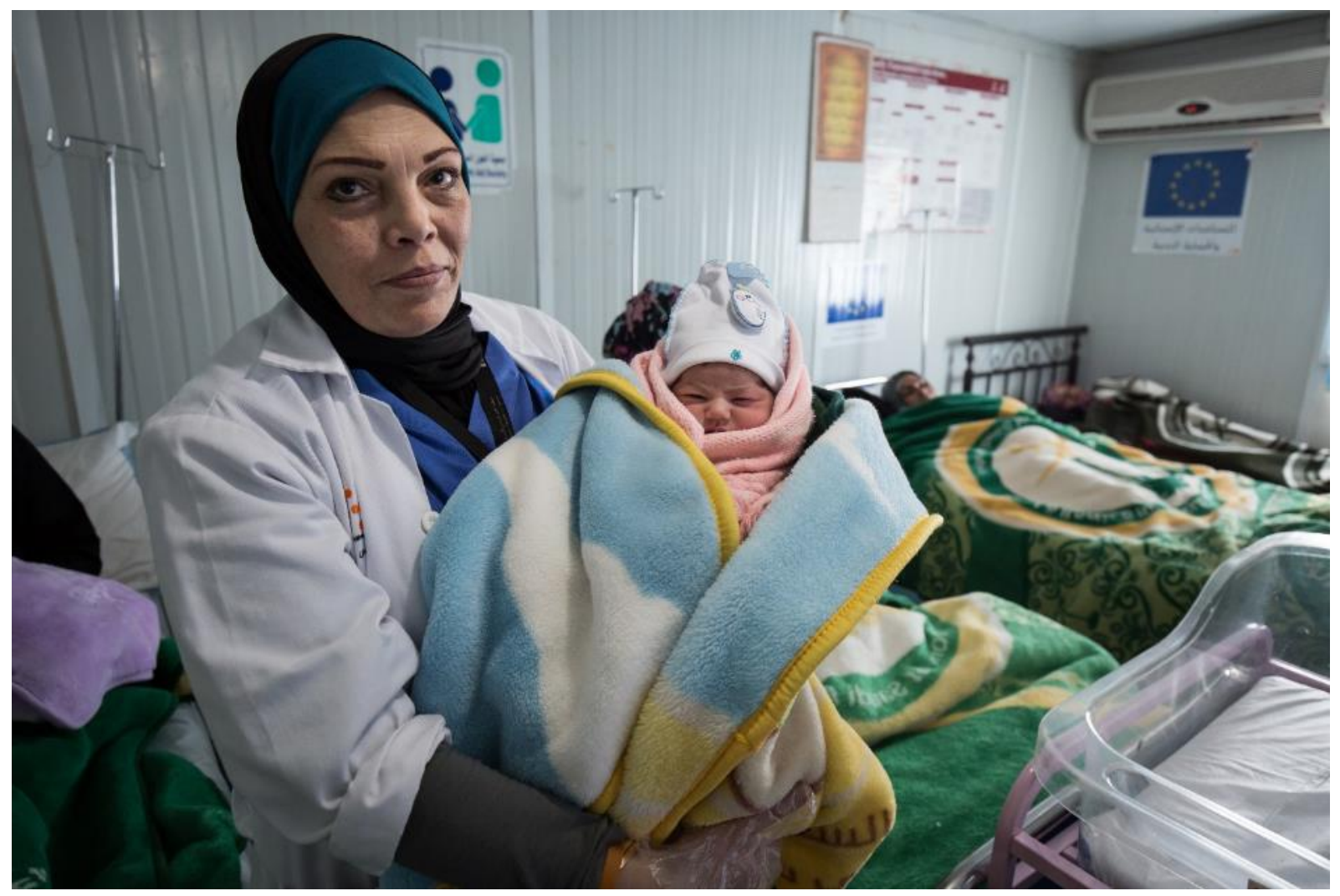

A doctor holding a baby in the maternity centre at the Zaatari refugee camp in Jordan, which hosts around 80,000 Syrians fleeing the war. Photo: Tom White/PA.

- Public services like health and education, as well as child benefits, pensions and other social protection have huge power to reduce inequality.

- To do this they must be high quality, universal, public and free, and promote gender equality.

\section{DELIVERING AN EVERYDAY MIRACLE}

Classrooms with teachers. Clinics with nurses and doctors. Working taps and clean toilets. A basic pension at the end of a hard-working life. Education, health, water, pensions, child benefits that are available to all people regardless of gender, caste, ethnicity or disability. Public services and social protection benefits such as these can be engines of equality, working to transform people's lives and unlock potential, pull societies together and close the gap between rich and poor and between women and men. 
Public services are one of humanity's greatest inventions. No country has developed without investing in them. In rich countries in the $19^{\text {th }}$ century, schooling and healthcare were almost entirely in private hands and out of reach for most people, ${ }^{234}$ who suffered as a result. Public services in those same countries today are the most powerful equalizers, reducing income inequality by an average of $20 \%{ }^{235}$

Public services and social protection play a fundamental role in meeting the needs and human rights of people the world over. They also have a very powerful role in reducing both inequality and poverty. ${ }^{236}$ Evidence from more than 150 countries, rich and poor alike, spanning a period of more than 30 years, ${ }^{237}$ shows that investment in health, education and social protection reduces the gap between rich and poor. One recent review of 13 developing countries found that spending on education and health accounted for $69 \%$ of the total reduction of inequality. ${ }^{238}$

Universal and free public services meet essential needs, save people from paying out of pocket, and offer an escape route out of poverty for hundreds of millions of people. If all children left school with basic reading skills, 171 million people could be lifted out of extreme poverty. ${ }^{239}$ One hundred million people would be prevented from falling into extreme poverty each year if universal healthcare was publicly funded and free of charge to patients. ${ }^{240} \mathrm{~A}$ further 800 million people would no longer have to forego other basic necessities, like food, as a result of paying for healthcare. ${ }^{241}$

Each day people - mostly women and girls - spend 125 million hours collecting water. ${ }^{242}$ An estimated 443 million school days are lost each year due to water-related illness ${ }^{243}$ and about half of the developing world's hospital beds are occupied by people suffering the same. ${ }^{244}$ With access to clean water, these lost hours could instead be spent learning and earning for a better future.

The IMF has identified public spending on health, education and social protection as among the most important tools available to governments to reduce inequality and poverty, and stated that they are crucial to promote economic development. ${ }^{245}$ 
Many developing countries today operate public services on a scale impossible to conceive of in the history of rich nations when they had comparable income levels.

For example, Thailand introduced universal health coverage in 2002 for its population of 69 million people, with a per capita income similar to that of the US in $1930 .{ }^{246}$ The Thai government employs 180,000 nurses $^{247}$ and 50,000 doctors $^{248}$ countrywide. Over $80 \%$ of all care is delivered by the state. Funded by progressive taxation, quality health services are available free to everyone, rich and poor. ${ }^{249}$ They help to reduce inequality in Thailand by benefitting poor people more than the rich. ${ }^{250}$

Ethiopia is a poor country, with around the same per capita income as Canada in 1840. ${ }^{251}$ However, it is the fifth-largest spender on education in the world as a proportion of its budget:

- It employs over 400,000 primary school teachers. ${ }^{252}$

- Between 2005 and 2015, it has brought an additional 15 million children into school, from 10 million to 25 million. ${ }^{253}$

Ethiopia still faces serious challenges with learning outcomes and improving the quality of education, ${ }^{254}$ but the scale of its commitment and effort to educate its girls and boys is dramatic.

Through concerted government action and public delivery, working with communities, the Government of Paraguay increased the percentage of the rural population accessing clean water from $50 \%$ to $95 \%$ in just 15 years (2000-2015), ensuring that every citizen can drink clean water. ${ }^{255}$

\section{PROGRESS, BUT PATCHY AND UNEQUAL}

In recent decades, public services, especially in developing countries, have delivered some remarkable results. Since 1990, 2.6 billion people have gained access to improved drinking water. ${ }^{256}$ Primary school enrolment is now almost universal, with as many girls enrolling as boys. ${ }^{257}$ Since 1990, the number of children dying before their fifth birthday has halved. ${ }^{258}$ Globally, new HIV infections declined by $38 \%$ between 2001 and 2013. ${ }^{259}$

Unfortunately, progress in meeting other essential needs has been unacceptably slow or has even reversed. At least half the world's 7.6 billion people do not receive the essential healthcare they need. ${ }^{260}$ In 2015, there were 262 million primary and secondary age children still out of school. ${ }^{261}$ Of those in primary school, more than half do not reach even a basic level of reading. ${ }^{262}$ And 844 million people still lack even a basic drinking water service. ${ }^{263}$

Global aggregates also mask huge differences in progress between and within countries, between rich and poor, and between women and men. In developing countries, children from the richest families are $32 \%$ more likely to complete primary school than children from the poorest families. ${ }^{264}$ Evidence from 137 developing countries shows that a child 
from a poor family is on average twice as likely to die before their fifth birthday than a child from a rich family. ${ }^{265}$

For an expectant mother giving birth, the presence of a midwife or other health professional will dramatically improve her chances of survival if something goes wrong. For poor expectant mothers, it matters hugely which country they are giving birth in, as Figure 5 shows. In Thailand and Rwanda, poor mothers are almost as likely as rich mothers to give birth with the help of a medical professional, whereas in Indonesia and Ghana they are much more likely to have to give birth without any professional help, putting their lives and the lives of their babies at risk.

Figure 5: Percentage of births with assistance of midwife or other skilled medical professional - poorest $20 \%$ and richest $20 \%$

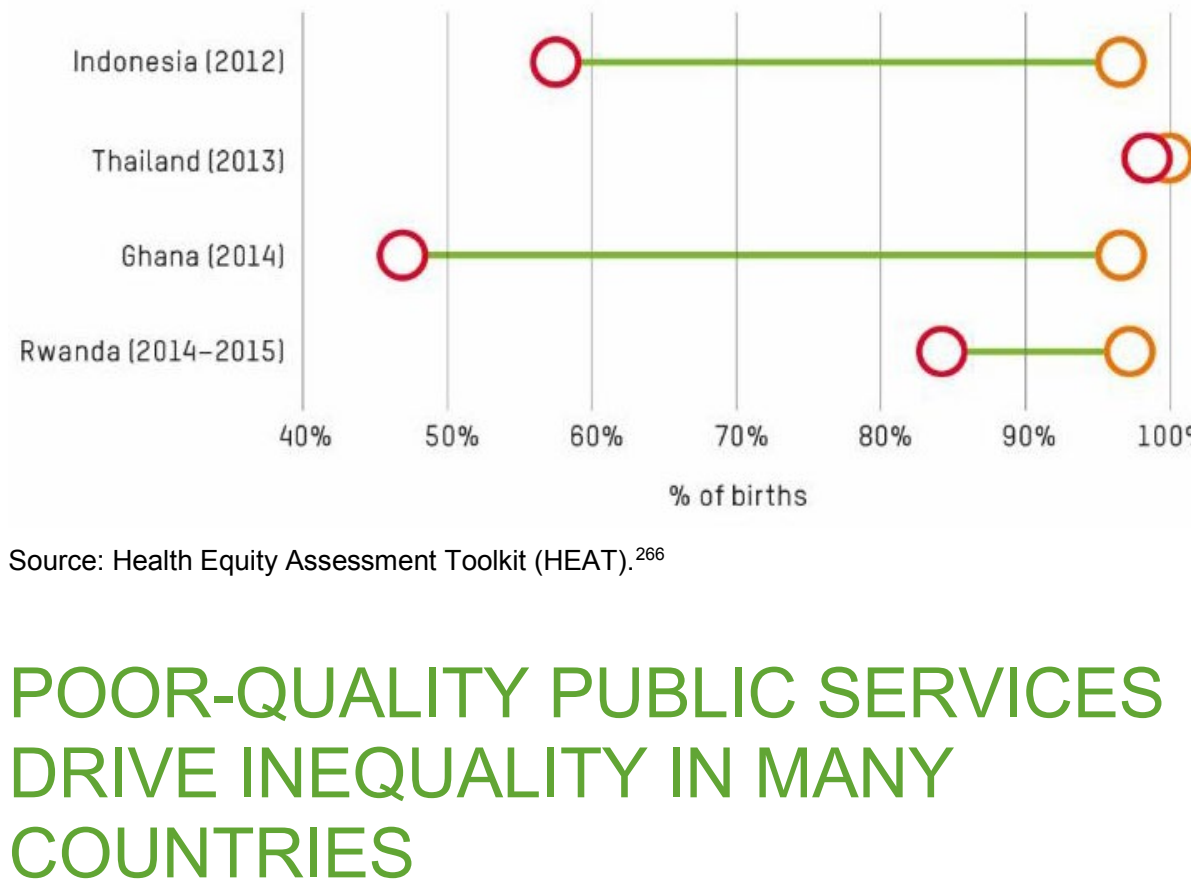

The power of public services and social protection to reduce inequality depends on how well they are funded, how they are delivered and their level of quality.

In too many countries, public services face a quality crisis. Schools and clinics are poorly staffed, underfunded and of very low quality. Social protection is miserly and excludes many who need it. Services ignore the specific needs of women. In such situations, public services can fail to serve citizens and end up reinforcing and increasing inequality.

Across low- and middle-income countries, it is estimated that 3.6 million deaths each year can be attributed to the lack of access to healthcare. ${ }^{267}$ 
In India, government neglect of public healthcare means the private sector dominates. ${ }^{268}$ The highest-quality private medical care is only available to those who have the money to pay for it. ${ }^{269}$ The country is a top destination for medical tourism, with some of the best-quality care in the world available to those who can afford it. ${ }^{270}$ At the same time, levels of public spending on health are some of the lowest in the world. In South Asia, including India, poor-quality care kills more people than lack of access to treatment and care. ${ }^{271}$ The poorest patients either have to cope with very poor public providers or take their chances with an array of unregulated quacks and other private providers, often bankrupting themselves in the process. $^{272}$

Powerful private health corporations have escalated the cost of government-paid health insurance premiums three and a half times in some states, and threaten to withdraw services if governments do not comply. ${ }^{273}$ In major cities like Delhi, many private hospital corporations have received free or heavily subsidized land from the government in return for providing free care for poor patients, which they consistently fail to deliver. ${ }^{274} \mathrm{~A}$ number of these same hospital corporations have received substantial financial backing from the private sector investment arm of the World Bank. ${ }^{275}$

Eighty percent of payments to the government health insurance scheme go to private providers. Evidence across different states confirms unethical and corrupt practices by private providers, include charging the government for bogus patients, refusing free treatment to poor patients, and delivering unnecessary interventions and medication. ${ }^{276}$ Perhaps the most horrific example of the latter is that thousands of young Indian women have their uteruses needlessly removed by private healthcare providers because hysterectomies are among the most profitable procedures. ${ }^{277}$

Millions more children, most of them girls, now get to go to school because of the expansion in access to education in many poor countries. Yet in too many countries, this historic increase in access for poor children has not been met with the investments also needed to ensure that the education they receive is of good quality. As a result, many countries face a learning crisis, where children are failing to secure even the most basic skills. ${ }^{278}$

Failing public water provision means that poor families are forced to buy water from private vendors, often for much higher prices than those paid by the better-off who have access to public water supply. In Nairobi, for instance, slum dwellers can end up paying up to 40 times more for their water than those in wealthier areas of the city. ${ }^{279}$

Public services in too many developing countries are piecemeal, privatized and privilege the rich. While some countries buck the trend, in most health and education spending is far too low. ${ }^{280}$ For many years, the main economic view from institutions like the World Bank was that public services and social protection should be rationed and minimal; that the private sector is better at providing support; that individuals should pay for their schools and hospitals; that market mechanisms should be used in public services; and that social protection should be very limited 
and targeted only at the very poorest people. ${ }^{281}$ While some of the rhetoric, programming and advice has changed, including notably from the IMF, ${ }^{282}$ change in practice has been slower. Austerity in rich and poor countries alike following the global financial crisis of 2008 has overwhelmingly protected the interests of the rich while cutting back the public services and social protection upon which the poorest and most vulnerable people depend. ${ }^{283}$

This trend is often compounded by the influence of elites over politics and governments, skewing public spending in favour of corporate interest (see Box 6). ${ }^{284}$ Similarly, pharmaceutical companies use their lobbying power to insist on exceptionally high prices that are beyond the reach of ministries of health. ${ }^{285}$ For example, a new medicine to treat drugresistant TB was priced by Janssen, a subsidiary of Johnson and Johnson in South Africa, at $\$ 400$ for a six-month course, when researchers estimate that a generic version could be made for only $\$ 48.286$

\section{HOW CAN PUBLIC SERVICES AND SOCIAL PROTECTION REDUCE INEQUALITY?}

\section{Reducing poor people's expenses}

When a government provides free universal public services like education or health, it benefits everyone. In income terms though, it benefits the poorest women and men the most because they don't have to use their very low earnings to pay for these services. Spending by government in this way can be seen as a significant virtual ${ }^{287}$ boost to the incomes of households. For the poorest people this boost can be worth as much, if not more, than their regular earnings. ${ }^{288}$

To find out more about these positive effects, Oxfam has looked at available public spending data for primary education across 78 low-, middle- and high-income countries. ${ }^{289}$ Our calculations find that in $90 \%$ of the countries, the amount the government spends per child in primary school each year is worth more than the income of the poorest $10 \%$ of the population. ${ }^{290}$ The scale of the benefit for poor families will depend on their size and how many children they have in school. This boost to family income can be true in rich and poor countries alike. For a single mother with two children both in primary school, for example, public spending on her children's schooling exceeds her family income by three times in Colombia, and more than doubles it in countries as diverse as Brazil, Latvia, Senegal and Romania (see Figure 6). 
Figure 6: Public spending on primary education compared to income of the poorest families in various countries

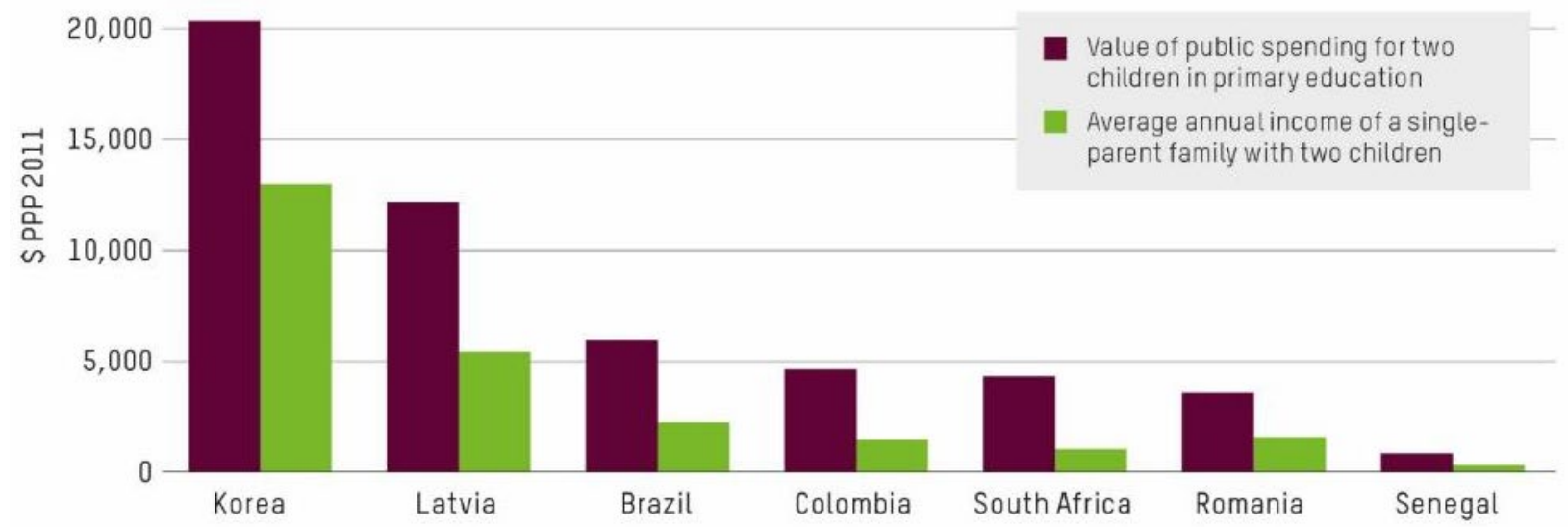

Source: Oxfam calculations. See methodology note. ${ }^{291}$

The disproportionate income benefit to poor people is also true for the provision of other free or heavily subsidized public services. People in poverty often spend a significant proportion of their income on water, with the cost of water in Papua New Guinea being as much as $54 \%$ of a poor person's daily wage ${ }^{292}$ Reducing the cost of water saves poor families a lot of money, reducing both poverty and inequality. ${ }^{293}$ On average, in rich countries, public services are worth the equivalent of $76 \%$ of the disposable income of the poorest people, and just $14 \%$ of that of the richest. ${ }^{294}$

In addition to these freely provided services, social protection schemes like child benefit and pensions mostly provide additional cash income. These too can have a major impact on reducing inequality. Evidence from Latin America shows that the introduction and expansion of social protection was one of the key drivers of inequality reduction in the region during the 2000s. ${ }^{295}$

Beyond the direct impact of government spending on redistributing incomes, when delivered well, public services and social protection can reduce inequality in other important ways.

\section{Impact on women}

Women and girls living in poverty stand to gain most from high-quality, universal and equitable public services and social protection. ${ }^{296}$ These should not only be designed to meet the needs of women. They should also challenge wherever possible the traditionally perceived roles of women and men, for example policies to ensure fathers and mothers share parental leave rather than only giving maternity leave to mothers.

Globally, women with secondary education earn twice as much as women with no education. ${ }^{297}$ Education therefore narrows women's pay gap with men; it also increases their decision-making power in the household. In Pakistan, for example, women with only a primary education earn around half of men's wages, while women with a 
secondary education earn around $70 \%$ - still an unacceptable gap, but a far narrower one. ${ }^{298}$

UNESCO estimates that if all girls were to receive a secondary education, there would be a $64 \%$ reduction in early and forced child marriages. ${ }^{299}$ Such marriages greatly increase the risk of death in childbirth. ${ }^{300}$ If all girls completed even a primary education, an estimated 189,000 maternal deaths would be avoided annually - a reduction of twothirds. ${ }^{301}$ Public education can be truly transformative for girls and women if schools are used as spaces to challenge the attitudes of parents and communities that act as barriers to gender equality.

Around the world, universal social protection transfers, like pensions and child benefits, narrow the income gap between women and men. ${ }^{302}$ In South Africa, for example, women's income is worth $48 \%$ of men's before these transfers, and $57 \%$ after. Universal social protection is usually better at contributing to gender equality than social protection schemes that are based on individual contributions. Contributory schemes are less accessible for women, because women often work informally and precariously, so do not qualify for the benefits. ${ }^{303}$ Even when women do contribute, their benefits tend to be lower because of their lower earnings and longer periods without paid employment due to caring responsibilities. ${ }^{304}$

Good-quality, free healthcare is essential for women and girls to be able to make decisions about their own lives and be active and productive members of their families and communities. It increases their chances of escaping poverty and reduces their chances of dying from preventable causes, such as childbirth. Access to sexual and reproductive health services is essential for women to enjoy autonomy and make choices about whether and when to have children. This in turn has profound impacts on women's economic opportunities. ${ }^{305}$

Conversely, fees for healthcare can widen inequality between women and men. In Mali, one in-depth study found that user fees 'trap women and their families in cycles of poverty, disease and powerlessness'. Women on low incomes had to wait for their husbands to decide whether to pay for needed care or not. ${ }^{306}$

\section{Boosting social cohesion}

Public schools, public hospitals, public housing and, public water supply. Universal benefits, for all mothers, for all children and older people.

These actions by governments can have a powerful equalizing impact on society. Good-quality public schools can be beacons of equality, where the children of rich and poor families learn together and can become friends. People from all classes and backgrounds can meet at the local public park or health clinic. All mothers can receive support from the government, regardless of their level of income. These are everyday examples of how society can be designed to pool risks, to enable people to help each other stay healthy and cope with risks they could not manage on their own. ${ }^{307}$ 
In the immediate post-independence period of many countries, the expansion of universal public services was integral to the nation-building project. ${ }^{308}$ A number of countries explicitly use social protection and public services as a tool to strengthen citizen-state relations and promote unity. ${ }^{309}$ A study of universal cash transfers in a district of Nepal found that they led to perceptions of equality among the beneficiaries, thereby promoting social inclusion. ${ }^{310}$ In India, traditionally those from so called high-caste backgrounds are not supposed to use the same eating utensils as those from so called low-caste backgrounds. While prejudice still continues to exist, there is some evidence that school feeding programmes in public schools have contributed to breaking down this practice, as positive instances have been observed where all children eat together. ${ }^{311}$

However, when services or grants are targeted they can foster divisions and conflicts. In several Latin American countries, poverty targeting was found to weaken social engagement in poor communities. ${ }^{312}$ Studies of Nicaragua's social protection scheme Red de Protección Social revealed growing divisions between recipients and non-recipients, who refused to take part in community activities. ${ }^{313}$

When public services fail, rich people can use their money to opt out. They may in turn have less interest in or support for public services, and be less willing to pay taxes to fund them. ${ }^{314}$ Low-quality, underfunded education, health and other public services become the preserve of the poorest people, ${ }^{315}$ and social cohesion, trust and solidarity are undermined. ${ }^{316}$

\section{Powering social mobility}

As described in section 1, social mobility, or the ability to move up the income ladder, is central to reducing inequality and fighting poverty. Good public services and social protection have significant potential to increase social mobility.

This is particularly true of education: if a good education is available to all, then the opportunity for all children to fully realize their potential and make the most of their abilities is clear. ${ }^{317}$ Conversely, if a good education is only available to those with money, talent is stifled and the richest people can hoard opportunities.

\section{Liberation and freedom}

Public services and social protection can tackle inequality by providing freedom conviction most famously held by Nobel Prize-winning economist Amartya Sen. ${ }^{318}$ While nominally free, most of humanity remains imprisoned by poverty, illness and ignorance. Freedom from these is, for Sen, a core measure of human progress.

Good-quality education can transform lives. It can have a profound impact on people's self-awareness, self-confidence, critical thinking and understanding of the world. It can give them the power to challenge their leaders and demand a fairer world. ${ }^{319}$ It can help fight plutocracy and 
build democracy. Extensive research in OECD countries, dating back to the 1970s, shows that increased education leads to greater political and civic engagement. ${ }^{320}$

Women and girls living in poverty, who are currently losing out the most, stand to gain most opportunities to increase control over their lives through education ${ }^{321}$ and access to health services. Provision of quality childcare facilities or piped clean water can free them from hundreds of hours currently spent looking after children or collecting water, giving them time for leisure, learning, activism or paid work.

\section{WHAT KIND OF PUBLIC SERVICES AND SOCIAL PROTECTION MAXIMIZE THE REDUCTION IN INEQUALITY?}

The way that public services like health and education are delivered, and the way in which social protection benefits like pensions and other welfare payments are organized, is critical to how much they reduce the gap between rich and poor and between women and men.

Successful governments have achieved results by providing universal public services and social protection that work for women and girls; abolishing fees in health and education; scaling up public delivery of services, including training and recruiting nurses and teachers; and ensuring that services are accountable and responsive. Above all, they have delivered quality services for all - not just for those who can afford them.
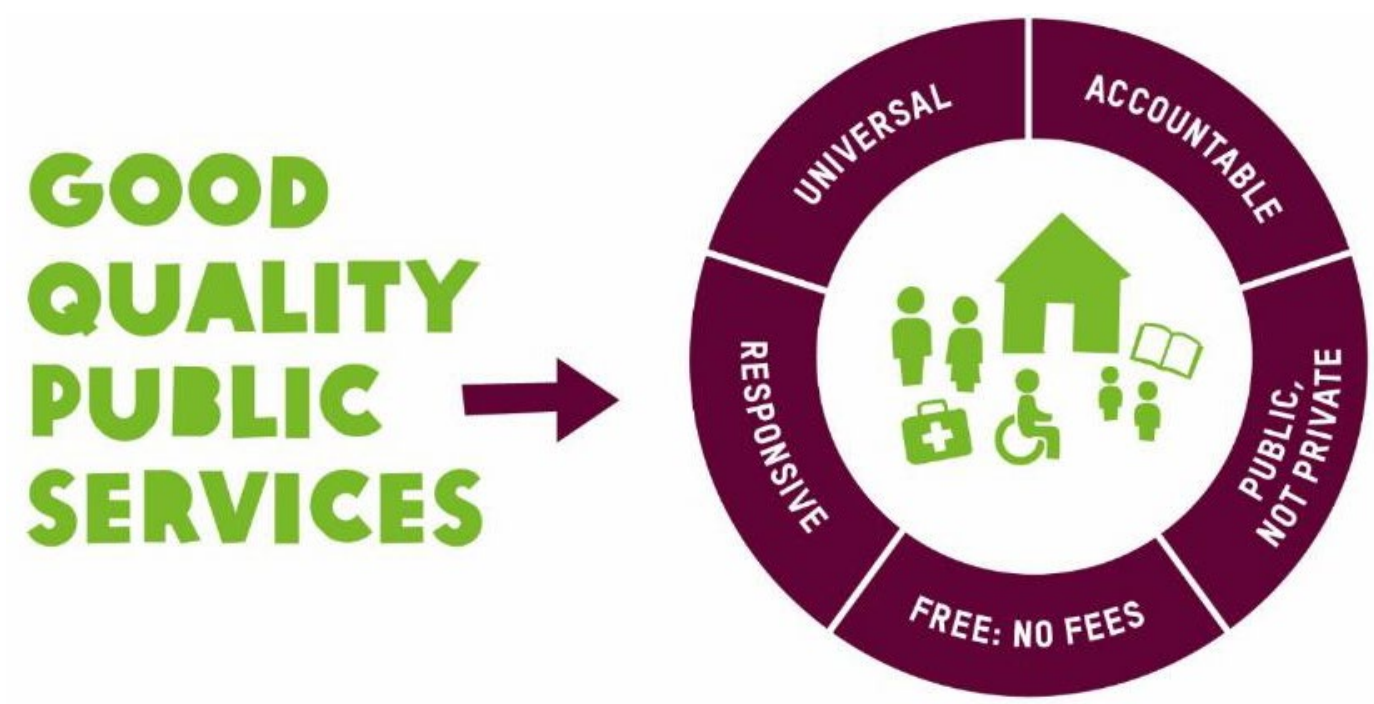

\section{Universal}

Public services and social protection work better at reducing inequality if they are universal and the right of all citizens.

After World War Two, the first full welfare states were built on the idea of universalism. This was bound by a clear political logic - that good 
universal public services and social protection benefits, available to all citizens, were popular with rich and poor alike. They bound society together and generated a willingness among all to pay adequate taxation towards them. ${ }^{322}$

In the 1960s and 1970s, universal approaches to public services and social protection prevailed in both rich and poor countries. ${ }^{323}$ Since the 1980s however, with a global debt crisis and the rise in neo-liberal economics, ${ }^{324}$ influential institutions like the World Bank increasingly promoted the targeting of social benefits to specific identified groups. ${ }^{325}$ The Bank contends that while we should aim for universal social protection, it is unaffordable for most countries ${ }^{326}$ and should therefore only be targeted at the poorest people. In promoting this approach, the IMF, World Bank and international aid donors have been accused of ignoring post-war history and exporting $19^{\text {th }}$ century style 'poor relief' to developing countries. ${ }^{327}$

Many countries have shown that universal public services are affordable. ${ }^{328}$ Even Nepal, one of the poorest countries, is showing the way through its universal old-age and disability benefits. Costs in healthcare can be kept down by focusing on primary care, so many health conditions can be treated before they become more serious and more expensive to manage. ${ }^{329}$

Targeting benefits at the poorest families and individuals can seem to make sense, but in fact is often unworkable. Poverty targeting systems are often ineffective, expensive and plagued with errors in both directions: leaving out those they are intended to benefit, and giving benefits to those not deemed to be in need. ${ }^{330}$ Figure 7 shows that the stronger the poverty targeting, the more those who should qualify are left out. Indonesia's PKH scheme is the most extreme example of this; it excludes $93 \%$ of those who should qualify for the benefits. Despite the evidence the IMF and World Bank have undermined universal schemes by proposing that governments introduce poverty targeting, including pushing Mongolia to target its universal Child Money scheme. ${ }^{331}$ 
Figure 7: Relationship between $\%$ of population covered by social protection scheme and $\%$ of qualified beneficiaries left out ${ }^{332}$

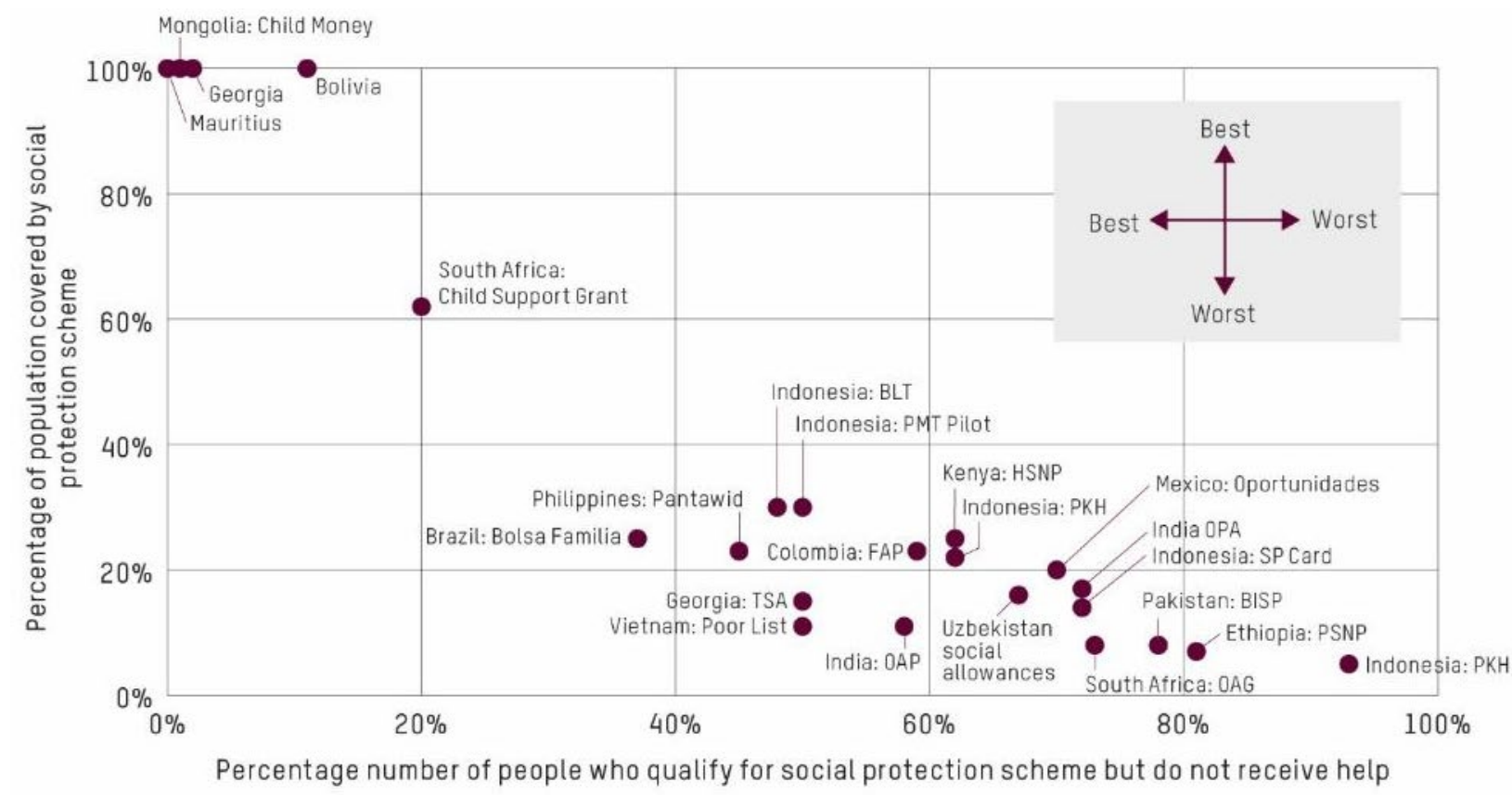

Source: Kidd, S.W, Gelders, B and Kidd, S.D. (forthcoming). Building a better future: a child-sensitive social protection system for Uzbekistan. Briefing paper to be published by UNICEF Uzbekistan.

Targeted schemes designed to advantage people living in poverty have frequently backfired because they can erode political support for income redistribution. ${ }^{333}$ As such, targeting is often followed by a reduction in benefits. ${ }^{334}$ Middle-class buy-in to universal public services and social protection is also important to keep pressure on governments to maintain and drive up quality for all. ${ }^{335} \mathrm{~A}$ study by UNICEF found that over the last 50 years, for the developing countries that have made most progress in providing widespread access to social services, universal access and provision was the guiding principle. ${ }^{336}$

\section{Public services should be free}

When health, education and other public services are not free, it is the poorest people who suffer most. It is hard to imagine a greater vulnerability than being seriously sick or injured with no means or power to get the healthcare you need. Yet that is the reality for the majority of people in the world. User fees are a life-or-death issue for too many citizens. In countries around the world, after controlling for other factors, the higher the share of health spending coming direct from people's pockets, the higher the rate of premature deaths. ${ }^{337}$

Each year, 100 million people are forced into extreme poverty and 800 million more face severe financial difficulties due to paying for their healthcare. ${ }^{338}$ This number is increasing. The fastest increase is in Africa, ${ }^{339}$ where two-thirds of countries still charge user fees for all levels of care. ${ }^{340}$ India is home to the largest number of people pushed into poverty by health expenses; paying for medicines is the chief cause. ${ }^{341}$ Medical bills are also one of the leading causes of personal bankruptcy in the US. ${ }^{342}$ 
In countries like Kenya, Democratic Republic of Congo (DRC), Malawi and India, at times poor people are held prisoner in hospital until they can pay; sometimes they are even chained. ${ }^{343}$ In one study of a health facility in the DRC over a six-week period in $2016,54 \%$ of women who had given birth and were eligible for discharge were detained for the non-payment of user fees. ${ }^{344}$ In many cases, women and babies are held for months and are denied ongoing healthcare until their bills can be settled. ${ }^{345}$ Dead bodies are not released for burial until bills are paid. ${ }^{346}$

The World Bank is an important player in global health, but its support for removing healthcare user fees is limited. ${ }^{347}$ Instead, it increasingly supports health insurance and other targeted schemes as an alternative. ${ }^{348}$ But health insurance can exacerbate inequality by directing public spending to those who are most able to pay for insurance, excluding many of the poorest and most vulnerable citizens. ${ }^{349}$ Health insurance is especially likely to exacerbate inequality in countries with large informal economies, where premiums cannot be automatically deducted from salaries, meaning payment is de facto voluntary. ${ }^{350}$ In Ghana, for example, the government health insurance scheme is predominantly accessed by better-off households and has a national coverage rate of just $40 \%$, despite having been in place for 15 years. ${ }^{351}$ The majority of the poorest people are not covered. ${ }^{352}$ In Germany, it took 127 years to achieve universal coverage through scaling up insurance. ${ }^{353}$ Insistence on insurance is likely to delay universal health coverage by decades, at huge human cost. Using general tax revenues is by far the quickest and most effective way to finance health for all.

More than a quarter of countries do not provide any free secondary education. ${ }^{354}$ Even when school is ostensibly 'free', formal and informal fees such as those for tuition, uniforms, food, transport and books can impose a severe financial barrier. Collectively, these fees and additional charges mean families bear $34 \%$ of total education expenditure in middle-income countries, rising to $49 \%$ in low-income countries. This hits poor families hardest. ${ }^{355}$

In Ghana, after fees for senior high school (upper secondary) were dropped in September 2017, 90,000 more students walked through the school doors at the start of the new academic year. ${ }^{356}$

With water services, unlike health and education, some fees are needed to encourage sustainable use of finite resources. It is critical however, that tariffs are structured to ensure that a minimum daily amount of water is provided free to support the poorest people. In South Africa, for example, the first 25 litres of water per person per day are free. ${ }^{357}$ 


\section{Public, not private}

When publicly delivered, services are made to work, the scale and speed of their impact on poverty reduction cannot be matched. ${ }^{358}$ This happens even in some of the poorest countries, as shown in Figure 8 below.

The World Bank has noted that the rapid expansion of governmentdelivered education in many developing countries has greatly outpaced the historic performance of today's rich countries. In the US, it took 40 years to increase girls' enrolment from $57 \%$ to $88 \%$ in 1910 . Morocco achieved the same in just 11 years. ${ }^{359}$ When pro-poor policy changes are made in public education systems, the impact is felt nationwide. The introduction of free universal primary schooling in Uganda increased enrolment by over $60 \%{ }^{360}$

One of the best ways to stop expectant mothers dying is to make sure that midwives or other skilled health professionals are there when they give birth. Our estimates, based on DHS data, suggest that in developing countries more successful at making sure the majority of poor women give birth with the support of a heath professional, this has been achieved overwhelmingly by public sector provision of care. In these developing countries doing the most to stop poor women dying in childbirth, $90 \%$ of the care that is provided comes from the public sector, and $8 \%$ comes from the private sector. (see Figure 8). ${ }^{361}$

Figure 8: Percentage of live births delivered by a doctor or midwife in public and private institutions by women in the poorest $20 \%-$ evidence from 61 low- and middle-income countries

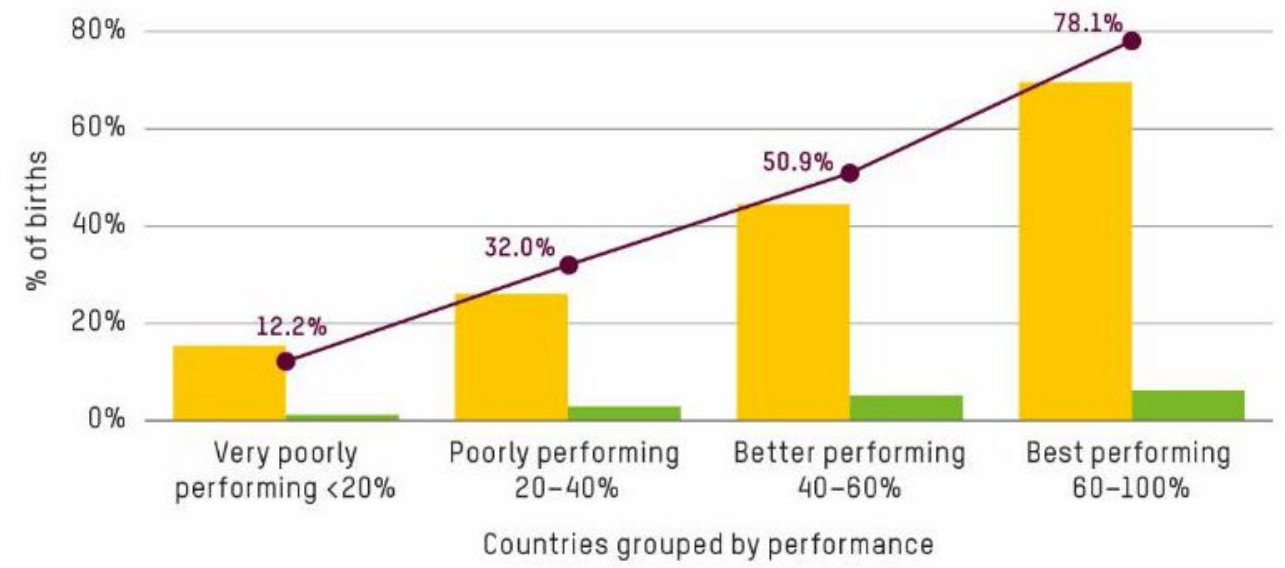

Source: P. Espinoza Revollo et al. (2019). Public Good or Private Wealth? Methodology Note. http://dx.doi.org/10.21201/2019.3651

But in too many countries, people are suffering for lack of good-quality and accessible public services. ${ }^{362}$ Rather than putting all efforts into addressing the many structural causes of such failings, influential institutions like the World Bank instead look to services delivered by the private sector as a solution. ${ }^{363}$

The market on its own will not deliver healthcare, education and other public services for poor people. The pursuit of profit means private providers have no incentive to serve those who are unable to pay. ${ }^{364}$
'The erosion of public health and education and the push to privatize them is driving up inequality across Latin America. What remains are good services for the rich and empty promises for the poor.'

- Coordinadora Regional FRESCE/Coordinadora de Desarrollo Institucional de la CLADE, Brazil

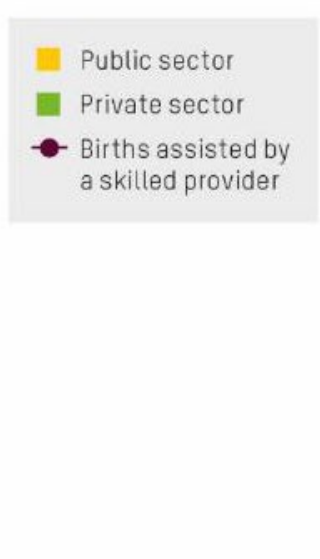


In recent years, donors like the World Bank have increasingly supported so-called 'low-cost' private schooling as an alternative to government provision. ${ }^{365}$ In education, poverty is a decisive factor in excluding children from private provision. It is rare for the poorest children to enroll in private schools, and when they do, their families have to make unacceptable sacrifices. ${ }^{366}$ One study in the Indian state of Uttar Pradesh found that even low-cost private schools are unaffordable for the poorest $40 \%$ of families, with girls and children from lower castes or religious minorities less likely to attend. ${ }^{367}$

A related approach promoted by some donors is to form public-private partnerships (PPPs). ${ }^{368}$ The theory is that the negative impacts of forprofit service delivery can be avoided, and the private sector can be harnessed by governments for the public good. Yet research shows ${ }^{369}$ that education, health and other public services delivered by for-profit providers and funded through PPPs come with significant risks, especially in terms of increasing inequality and cost escalation for governments. Even the IMF is now warning of the sizeable fiscal risks of pursuing PPP approaches. ${ }^{370}$

The water system of Indonesia's capital, Jakarta, was privatized in 1997 as part of a PPP. Twenty years later, most of the city still has no access to clean piped water, and the government has sustained huge losses which have been picked up by the taxpayer. Surabaya, Indonesia's second-largest city, has a public water supply that covered $95.5 \%$ of the population by 2016 . This is twice as much coverage as Jakarta Water, and the water is much cheaper. ${ }^{371}$

An Oxfam study revealed how a World Bank Group-advised new PPP hospital in Lesotho ended up consuming as much as $51 \%$ of the total health budget in 2014. ${ }^{372}$ Recent data suggests that the PPP hospital bill amounts to double the 'affordability threshold' set by the government and the World Bank before the PPP was signed. ${ }^{373}$ 


\section{Box 8: Education public-private partnerships in Pakistan - a}

dangerous diversion from public education

Pakistan has 24 million children out of school. ${ }^{374}$ Only $15 \%$ of poor rural girls finish primary school. ${ }^{375}$ Public spending on education is among the lowest in the world. Rather than build and improve the public education system, Pakistan is attempting to find solutions through partnerships with the private sector. Punjab state is leading the way. It announced in 2016 that no new public schools would be built. Instead, government funds would go to support private schools, and 10,000 government schools would be handed over to the private sector to manage. A key aim of this vast publicprivate partnership (PPP) was to get more of the 5.5 million out-of-school children in Punjab into education. ${ }^{376}$

Oxfam's research ${ }^{377}$ into the education PPP in Punjab and interviews with private school principals found that:

- Only $1.3 \%$ of children in the private schools surveyed had previously been out of school.

'We don't have any [formerly] out-of-school children in this school. The ones in the community don't want to study and can be a waste of our time.'

- A large majority of schools had enrolled more boys than girls, and dropout rates for girls were reported to be higher. In the face of non-fee expenditures like uniforms, many families choose to educate only their male children.

'Preference is always given to boys when it comes to private schools. Ours is a non-fee school, but still boys are given preference. This is because of various non-fee expenditures.'

- Non-fee expenditures per child in the schools surveyed represented $40 \%$ of the household income of the poorest households.

'The poor go to government schools in the area. They cannot afford any expenditure on education. We as school owners cannot include the poorest of the poor in this school with other kids. It's not like a charity; we have limited funds from the PPP, and I also need to earn a livelihood from this.'

- Teachers in the PPP are poorly paid and this also exploits gender inequality. Nine out of ten teachers in the schools surveyed were female. The average wage was one-fifth that of a public school teacher, and at $\$ 52$ was less than half the minimum wage for Pakistan.

In the PPP it is the teachers who suffer the most. I cannot pay a decent salary to my teachers. I cannot hire male teachers, as they demand a higher salary. Females have fewer options for work.'

Countries that are failing to deliver public services are also unlikely to be able to regulate commercial providers (see Box 8).

Civil society actors like NGOs, churches and mosques often plug the gaps where the state is failing to deliver. They can be a lifeline for the poorest people. But their services are piecemeal and vary significantly in their affordability and quality. ${ }^{378}$ The result is a lottery for citizens, depending on where they live and what they can afford. Successful governments have consolidated this patchwork of provision into one public system, to complement public schools and hospitals rather than compete with them. In Kerala state, the government funds the running costs of church schools and regularly inspects them to maintain standards. ${ }^{379}$ 


\section{Accountable}

To effectively fight economic inequality, public services and social protection need to be accountable and responsive to citizens. In many countries, Oxfam and allies are working to support citizens in demanding better and more accountable services. In Mozambique, since 2011 Oxfam allies have tracked allocations from the national budget to district budgets for education, health and other public services. They found that significant amounts of money had not arrived at the district level. These findings have been widely publicized and led to the government adopting national tools in 2016 to improve disbursements. ${ }^{380}$ In Vietnam, engagement with budget processes at local level by women's networks, supported by Oxfam, improved spending and public services. ${ }^{381}$

Since 2001, civil society groups, including patients' groups, successfully campaigned to decrease the price of HIV treatments, resulting in over 21 million people currently being treated. ${ }^{382}$ Action is now targeted at the high prices set for pharmaceutical companies' cancer medicines that are depriving people of life-saving treatments. ${ }^{383}$

\section{Responsive to the different needs of women and men}

Public services and social protection must be designed with an understanding that gender and other inequalities will affect how women and men will access them differently. Governments can ensure this happens by:

- Carrying out gender-based assessments of services to understand what might be holding women or men back from accessing them.

- Consulting with women's rights organizations and those representing marginalized groups, including LGBTI (lesbian, gay, bisexual, transgender, and intersex) populations.

- Prioritizing the types of services that would reduce inequality, including those that reduce and redistribute care work.

- Promoting women as workers in public services.

Well-designed public services and social protection must also work to challenge rather than reinforce accepted stereotypes about the roles of women and men, and push for greater equality. For example, in Rwanda, healthcare workers have engaged men during their partners' pregnancies, which has encouraged greater sharing of care roles. ${ }^{384}$

\section{Employing enough teachers, doctors and nurses}

Ensuring there are enough teachers, doctors and nurses is absolutely pivotal to the quality of public education and healthcare services. In many countries, where there is a lack of government cash or commitment, public services are kept afloat by a skeleton staff of overworked and underpaid teachers, doctors, nurses and other workers. Under appalling 
conditions, some do not do their jobs well or simply do not turn up. However, many more are deeply committed to their work, putting in long hours with few resources and little pay. For health workers, these conditions can be life-threatening, as the Ebola outbreak in West Africa in 2014 demonstrated, when large numbers of health workers gave their lives in the fight against the disease. ${ }^{385}$

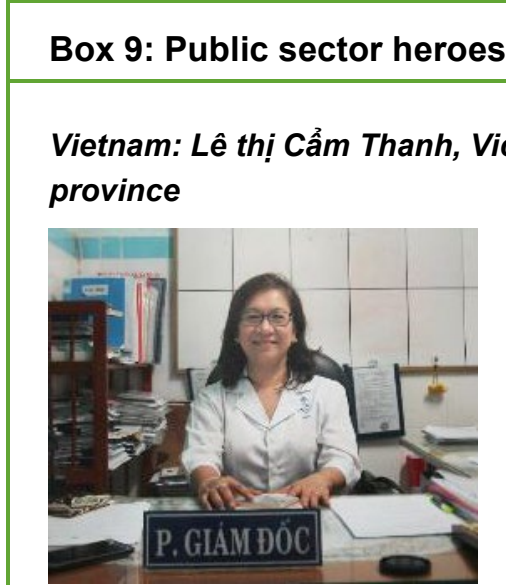

'I like my job. I spend most of my time working in communities where we can detect eye problems early and stop them getting more serious. When patients come to me, I have no profits, no money, but I feel happy to see the happiness of the patient who gets better. I want to use my knowledge to contribute to the care of people in the community. That's why I will be a doctor forever!'.

\section{Bolivia: Betty Carrillo Yujra, teacher}

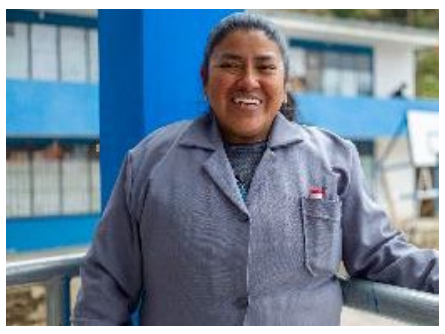

'I was the only one in my family who was able to finish school and study at university. I dreamt of being a teacher ever since I was a child. I get up every day at five in the morning, cook food for my two children and travel $40 \mathrm{~km}$ to the community where I work. I want to help create equality between children studying in the city and the children in my rural school, there should be no difference.'

Tunisia: Dr Dorra Bousnina Lassoued

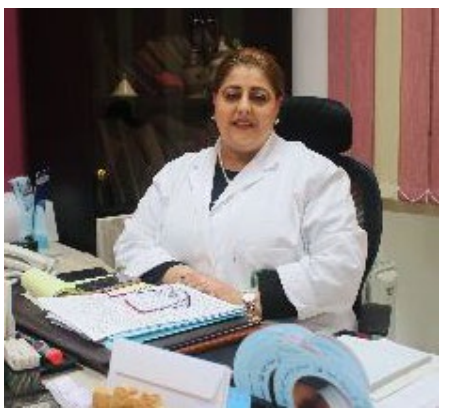

'My mother was a paediatrician, my father a cardiologist. Both were champions of the public health sector. Like my parents, I followed a public health career and I never thought of working in private health to enrich myself and enjoy life's goods. I chose instead to work in one of the most disadvantaged and dangerous neighbourhoods of Tunis.'

\section{Ghana: Sulemana Shukara, teacher}

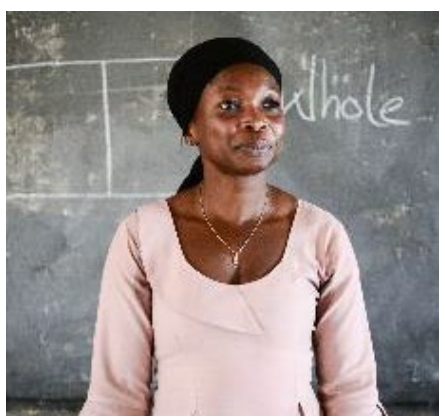

'When I came to this community as a teacher, I realized parents don't want to bring their children - especially the girls - to school. They believe that a girl belongs in the kitchen. So I took the role as a school guidance and counselling teacher. To counsel the parents. The girls, their place is not in the kitchen. One of my girls has now completed university of science and technology. I still want to see more results. So I am still working hard to achieve more'.

Photo credits, from top: Mr. Tran Loc; Alexandre Laprise; Slim Boussoffara; Jacob Stærk.

To deliver health and education for all, the world needs an additional 17 million health workers ${ }^{386}$ and 69 million teachers. ${ }^{387}$ In Senegal, there is 
one doctor per 14,000 people, compared to the one per every 1,000 recommended by the World Health Organization. ${ }^{388}$ Women are the majority of the world's teachers and nurses - around 143 million women are employed in health and education worldwide. ${ }^{389}$ Work in the public sector is often one of the few sources of formal employment for women. ${ }^{390}$ When women are at the front line of delivering services, their presence encourages other women and girls to use those services, and women workers act as important role models to other women and girls.

Universal public services and social protection are at the heart of reducing the gap between rich and poor and fulfilling the needs and rights of every person on the planet. They have the power to transform equality between women and men. They are within the reach of every government that has the will to reduce inequality.

The next section examines how, with progressive taxation and other actions, such services are affordable. 


\section{PAYING FOR UNIVERSAL PUBLIC SERVICES AND SOCIAL PROTECTION}

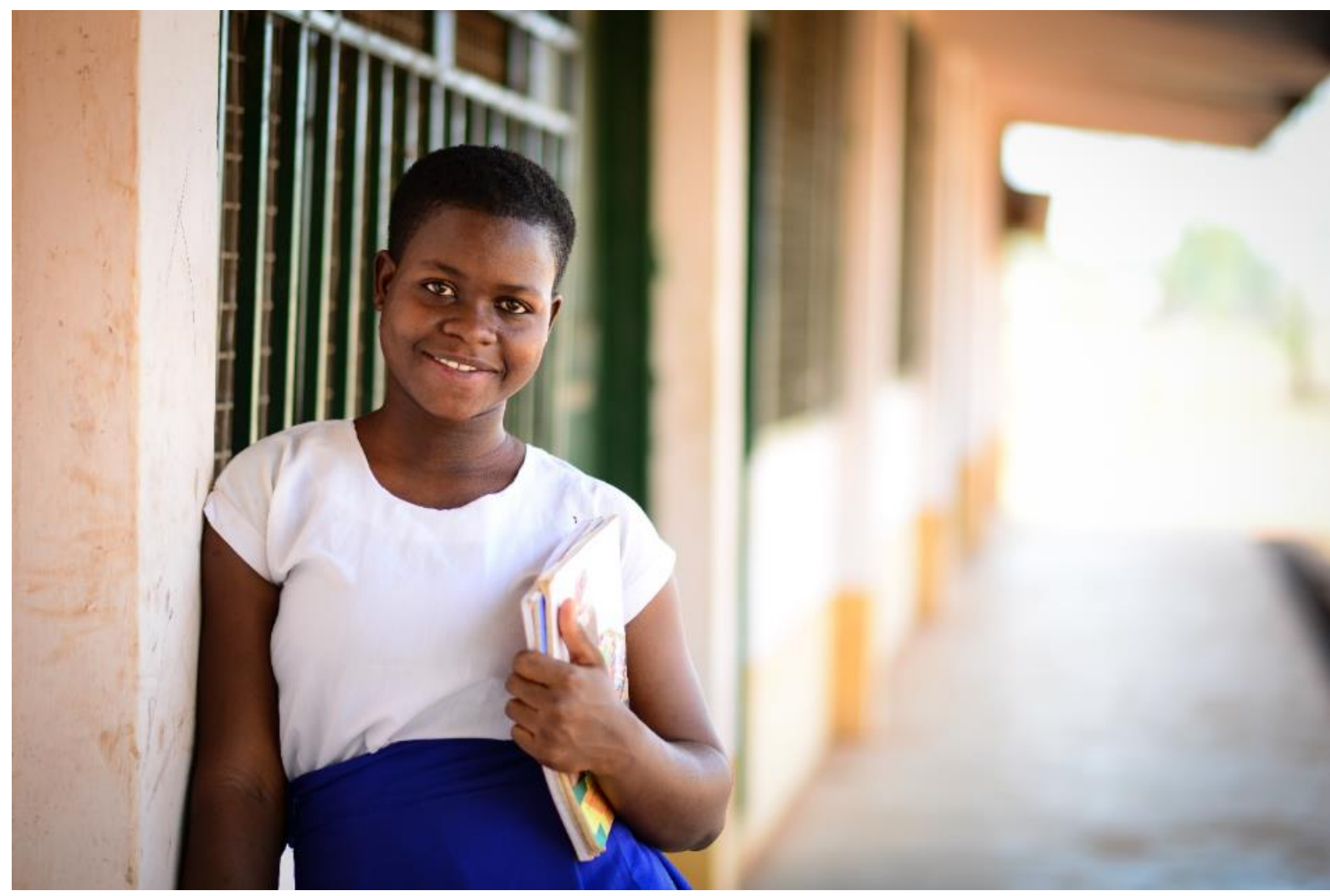

Celestina, 16, lost her father when she was in her early teens. A place at the Oxfam supported Girls Model School was her way out of poverty. 'If I hadn't gone to the Girls Model School my life would have been very miserable because I come from a poor home. But due to Girls Model School I am okay.' Celestina is currently studying at the senior high School in Tamale, and aspires to be a journalist: 'I want to reduce the rate of bribery and corruption in Ghana. It is a very big problem which has become rampant in Ghana.' Photo: Jacob Stærk.

- We can afford universal public services and social protection for everyone.

- To help pay for this, the richest individuals and corporations should pay their fair share of tax. They are currently failing to do this.

- Cracking down on corruption, tackling growing government debt and increasing high-quality aid are also essential to making this happen.

All governments have signed up to reducing inequality under SDG 10 where they commit to 'adopt policies, especially fiscal, wage and social protection policies, and progressively achieve greater equality'. ${ }^{391}$ The UN has estimated that it would cost a total of $\$ 1.4$ trillion a year to meet the SDGs in the poorest countries, which would include providing health, education, clean water and social protection. ${ }^{392}$ 
This section will show ways in which governments can help pay for this by:

- Raising revenues by making sure rich individuals and corporations pay their fair share of tax.

- Cracking down on corruption.

- Ensuring that international aid continues to play its vital role supporting the governments of poor countries.

- Tackling the growing threat of government debt undermining funding for universal public services.

It isn't a case of whether we can afford to do this We cannot afford not to.

\section{RICH PEOPLE AND CORPORATIONS MUST PAY THEIR FAIR SHARE OF TAX}

One way to fill the financing gap for delivering the SDGs is to raise more tax revenue from those most able to pay. The richest people and the corporations they own are undertaxed. As Figure 9 shows, governments in developed countries have been reducing both the top rate of personal income tax and the rate of corporate income tax over the long term. The top rate of personal income tax in the US was $94 \%$ in 1945, and as recently as 1980 it was $70 \%$. Today it is almost half that, at $37 \%{ }^{393} \mathrm{In}$ developing countries, the average top rate of personal income tax is even lower, at $28 \%$, and for corporate tax it is $25 \%$. ${ }^{394}$

Making use of exemptions and loopholes, the effective tax rates that rich people and corporations pay are lower still. ${ }^{395}$ Large companies are still paying less than 10 years ago. The effective rate of tax they pay has fallen by $9 \%$ since the financial crisis. 'This is in spite of a concerted political effort to tackle aggressive tax avoidance'. ${ }^{396}$ As most of their wealth is in financial assets such as shares, ${ }^{397}$ the super-rich are among the main beneficiaries of lower corporate tax bills as well as lower personal ones. Taxes on wealth, like inheritance taxes, have been cut by many countries in recent decades or are simply not being implemented. ${ }^{398}$ There is considerable scope for almost all countries to raise more tax from those most able to pay. ${ }^{399}$ 
Figure 9: Declining rates of taxation of rich individuals and corporations

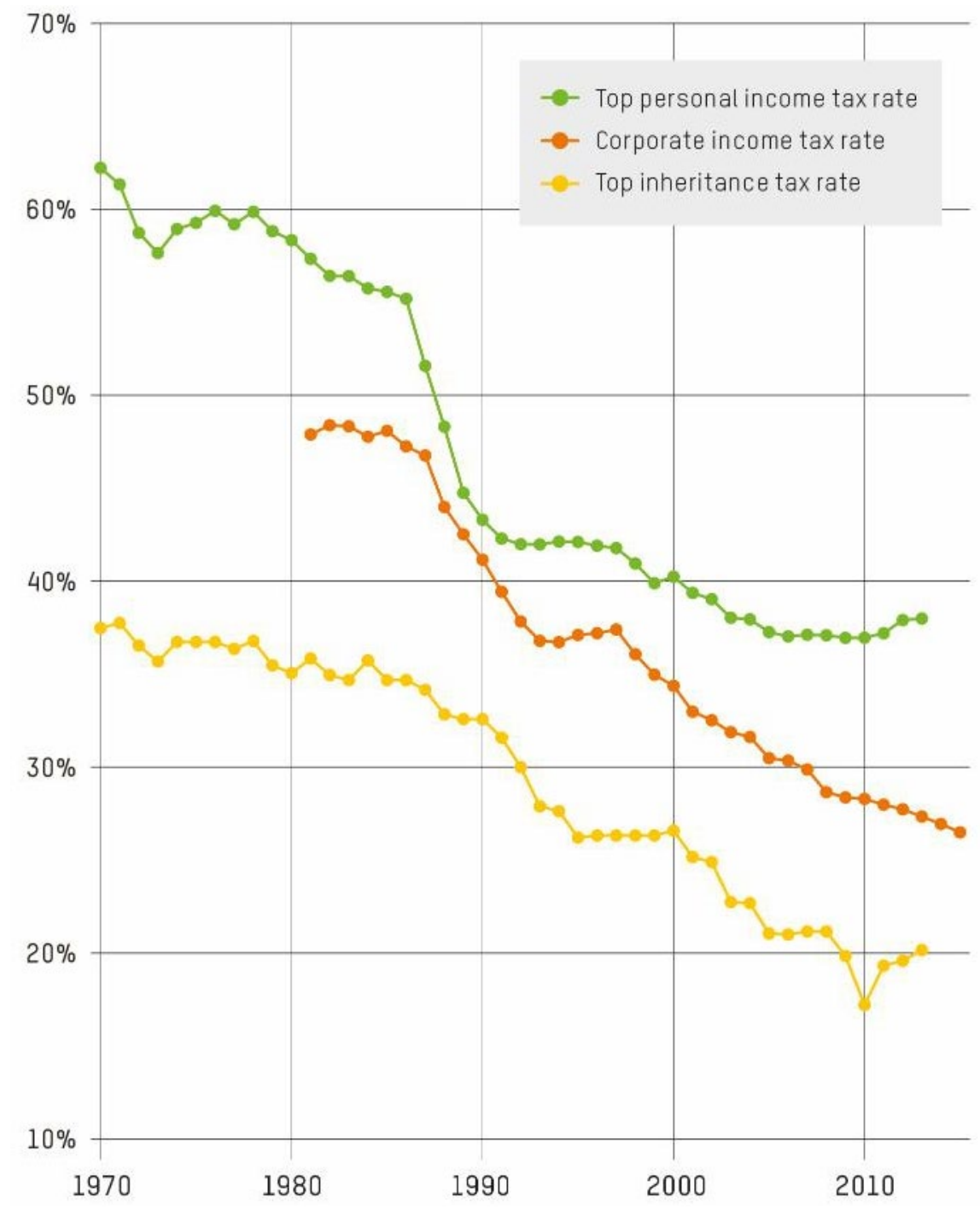

Sources: Scheve and Stasavage $(2016)^{400}$ for personal income tax and inheritance tax and Tax Foundation for corporate income tax. ${ }^{401}$ Note: Sample of 20 rich countries.

The failure to tax rich people and corporations more fairly is not only a missed opportunity to reduce inequality - it actually worsens it, as governments must resort to taxing the rest of society more, or cut spending on health, education and other public services and social protection that reduce inequality. Our analysis in Figure 10 shows that since the financial crisis of 2008 , the burden of taxation has shifted from corporations to families, and all the net increase in tax revenue is accounted for by payroll and consumption taxes like VAT. These taxes are often regressive because poor people pay a larger share of their income, so consumption taxes increase inequality (Box 10) (Box 10). ${ }^{402}$ This has contributed to the fact that in some developing countries, the government system of taxing and spending increases poverty rather than reduces it. In Chile in 2013 for example, the numbers of people living in poverty was increased by 222,000 because of government fiscal policy. ${ }^{403}$ 


\section{Box 10: A taxonomy of taxes}

\section{Corporation tax}

A tax levied on corporations and businesses. Generally progressive, in that its impacts fall more on the richest in society as they are the owners of corporations. Widespread tax dodging and poor collection undermine this impact. 404

\section{Personal income tax}

A tax levied on incomes. Generally progressive, with the rich paying higher rates, although widespread tax dodging and poor collection undermine this impact. ${ }^{405}$

\section{VAT and other sales and consumption taxes}

A tax levied every time someone purchases or consumes goods and services. Generally regressive, in that the poorest individuals pay the same rate of tax as the richest when purchasing something, and poor people also spend more of their money on consumption whereas the rich save a large proportion of their incomes.

\section{Payroll taxes}

Payroll taxes are taxes on salaries and wages. They mainly include social security contributions.

\section{Wealth taxes}

A tax levied on wealth directly or on the transfer of wealth. This includes a wide range of taxes: inheritance; property; taxes on financial transactions. It also includes taxes that are a simple percentage of the total wealth of individuals, called 'net wealth taxes'. These taxes are generally very progressive, impacting much more on the richest citizens.

\section{Figure 10: Tax revenue change 2007-2015 (\% GDP)}

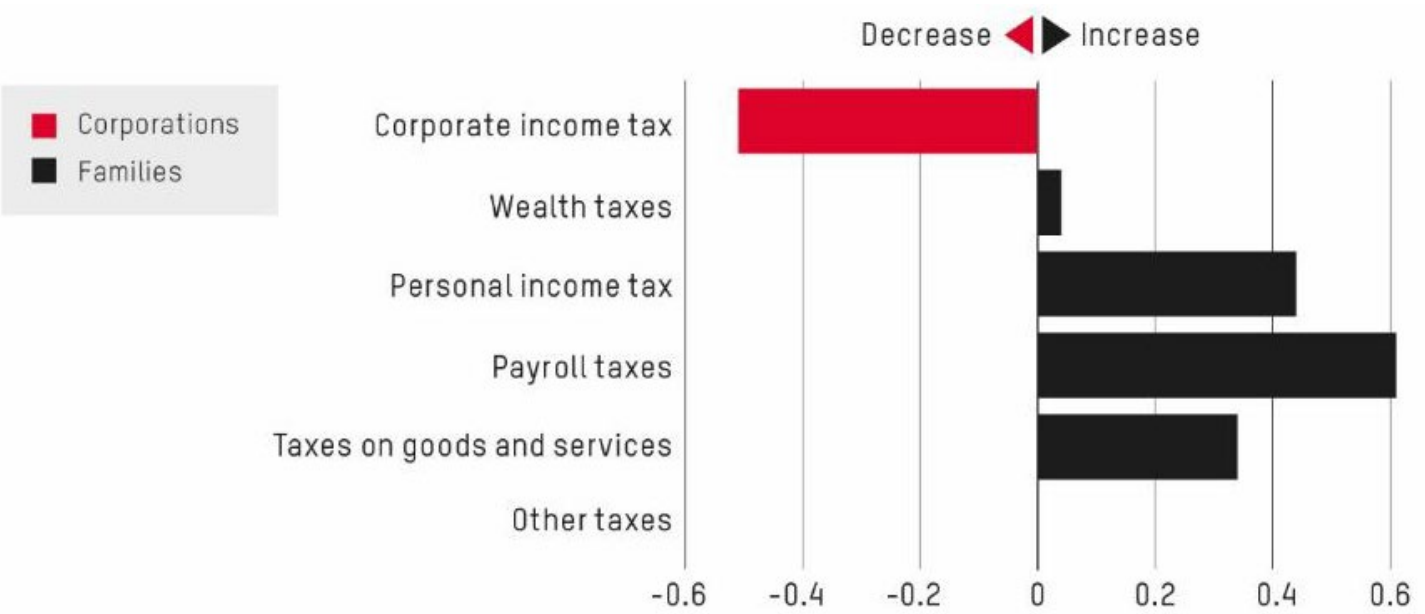

Source: Oxfam calculations based on OECD data available for 35 OECD and 43 non-OECD countries (unweighted averages). ${ }^{406}$ Axis figures represent $\mathrm{pp}$ - percentage points of GDP. Note: Payroll taxes include social security contributions and other taxes on salaries and wages. Taxes on goods and services include sales taxes and VAT.

While income inequality has increased in many countries ${ }^{407}$ since the 1980s, taxes have failed to redistribute more income. ${ }^{408}$ Indeed, billionaire Warren Buffett reminds us that he pays a lower tax rate than 
his secretary. ${ }^{409}$ His case is not exceptional. In some countries, when tax paid on incomes and tax paid on consumption (value-added tax or VAT) are both considered, the richest $10 \%$ are actually paying a lower rate of tax than the poorest $10 \%$.

\section{Figure 11: Effective tax rate for bottom $10 \%$ and top $10 \%$ in Brazil and UK}

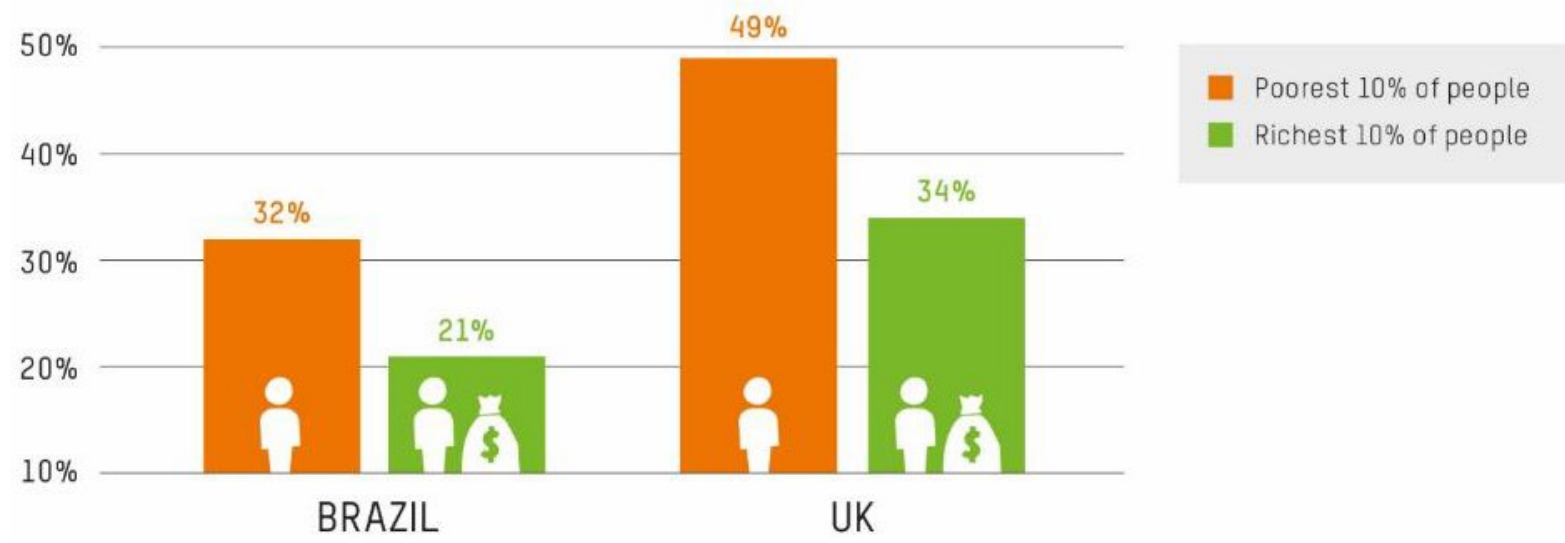

Source: INESC 2015 and UK Office for National Statistics $2018 .{ }^{410}$

Returns to the owners of wealth are also outstripping returns to workers in many countries. ${ }^{411}$ Automation is likely to increase this trend further. ${ }^{412}$ This disparity has been identified by many as one of the driving forces behind growing inequality. ${ }^{413}$ It has also meant that many commentators including the IMF, ${ }^{414}$ World Bank, ${ }^{415}$ Bill Gates ${ }^{416}$ and The Economist magazine ${ }^{417}$ have been calling for increased taxation of wealth to help contribute to a rebalancing of our economies.

As wealth begets power, a vicious circle can allow the rich to drive public policy such that they get even richer. ${ }^{418} \mathrm{~A}$ recently published study by Oxfam and CLACSO in Latin America documented 13 cases where the richest had used their power and influence to secure preferential tax rules. ${ }^{419}$

\section{Taxing wealth}

In addition to progressively increasing rates and tightening collection of personal and corporate income taxes, governments should pay more attention to taxing wealth itself. Wealth inequality is significantly higher than income inequality, ${ }^{420}$ so taxing wealth can make an important contribution to reducing economic inequality. ${ }^{421}$ It can also raise significant revenues for governments. Sadly, many countries have either reduced or failed to implement taxes on wealth. ${ }^{422}$ Even those wealth taxes that do exist are typically plagued with exemptions. For example, in Bangladesh, property taxes are based on the amount originally paid for the property and are not updated, meaning that minimal taxes are paid on large houses bought a long time ago in comparison to smaller houses bought more recently. ${ }^{423}$ In India, there were so many exemptions to the tax on net wealth that a typical individual was paying over eight times less than they should have been. ${ }^{424}$ In 2016 , instead of addressing the exemptions, the government abolished the tax. ${ }^{425}$ 
Governments should focus their efforts on raising more from the very wealthy to help fight inequality. For example, getting the richest to pay just $0.5 \%$ extra tax on their wealth could raise more money than it would cost to educate all 262 million children out of school and provide healthcare that would save the lives of 3.3 million people. ${ }^{426}$

The Move Humanity campaign has estimated that if the wealth of the world's billionaires were to be taxed an additional $1 \%$, this could raise \$100bn dollars annually. ${ }^{427}$

Although some of this revenue would be raised in poor countries, much of it would be raised in rich nations, where most of the world's wealth is. A share of these revenues should be redistributed from the rich in the rich world to the poor in the poor world, by increasing aid (see 'The role of international aid', below).

\section{Do higher taxes on the richest harm growth?}

For a long time, the orthodox economic view has been that imposing more taxes on the rich will harm everybody by stunting economic growth.

This 'trickle-down' orthodoxy is now being challenged. Research by the IMF shows that redistribution is generally benign for economic growth, and that many countries have considerable room to raise taxes on the richest without harming their economies. ${ }^{428}$ Economist Thomas Piketty argues that the optimal top rate of personal income tax could be as high as $83 \% .{ }^{429}$ Currently, the world's average top rate of personal income tax is $31 \% .430$

Inheritance taxes and to a large extent property taxes reflect unearned income, and therefore have little effect on growth. ${ }^{431}$ Inheritance taxes are central to promoting equality of opportunity and reducing the power of inherited wealth and privilege. ${ }^{432}$ They have long been a favourite target of attacks ${ }^{433}$ often based on misinformation, which has contributed to a dramatic decline in the amounts collected. ${ }^{434}$ Oxfam research showed how in Ecuador, opposition politicians and business people mounted a fierce campaign of misinformation against the proposed inheritance tax to mislead the public and generate opposition to this progressive move. ${ }^{435}$ Many people believe these taxes will negatively affect them, when in fact they are generally only levied on the very richest in society. ${ }^{436}$ 


\section{Fighting tax evasion and avoidance}

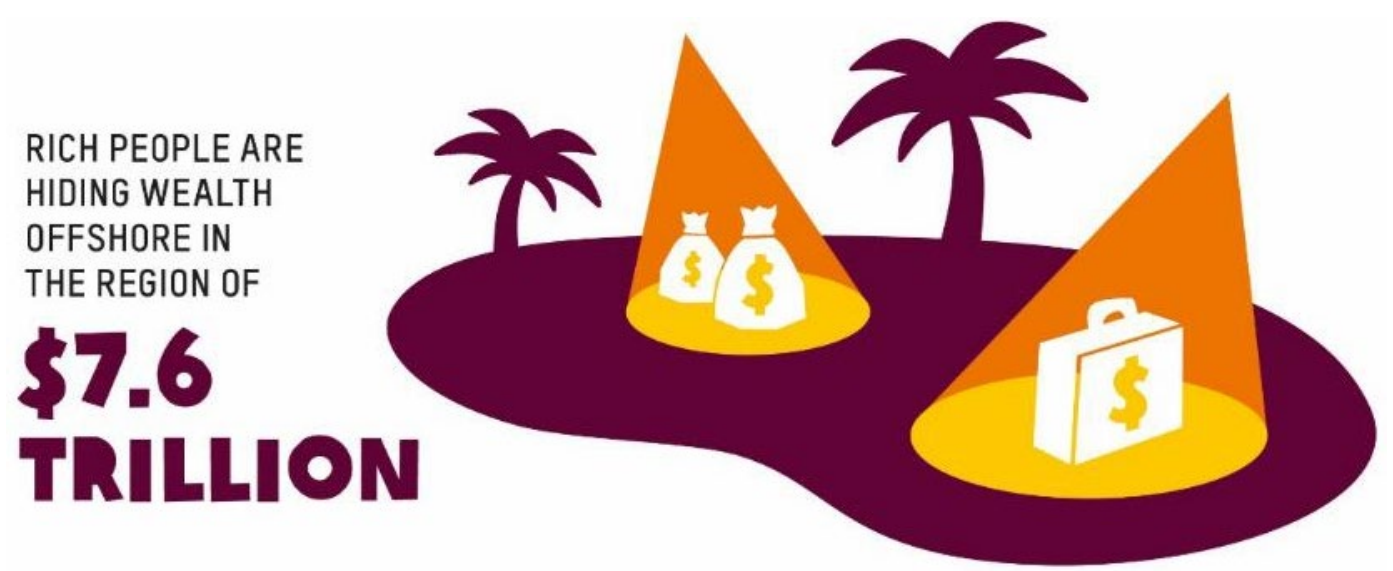

Source: G. Zucman. (2015). and the methodology note for Oxfam's 2018 Davos report ${ }^{437}$

Other barriers to ensuring that the rich pay their fair share are tax evasion, tax avoidance and tax competition. Capital can move across borders in search of secrecy and lower tax rates. The super-rich are hiding at least $\$ 7.6$ trillion from tax authorities and dodging an estimated $\$ 200$ bn in tax revenues. ${ }^{438}$ For Africa alone, as much as $30 \%$ of private wealth may be held offshore, denying governments $\$ 15 \mathrm{bn}$ in tax revenues. ${ }^{439}$ Multinational companies exploit loopholes in tax codes to shift profits to tax havens, costing developing countries an estimated $\$ 100$ bn in lost corporate income tax. ${ }^{440}$

Governments' efforts thus far to curb corporate tax dodging have been welcome, but half-hearted. ${ }^{441} \mathrm{~A}$ much more ambitious set of global reforms of corporate tax is urgently required. There is some indication that that a new process will begin at the G20 in 2019, which would be welcome. But any new process must seek genuinely fundamental reforms that reverse the race to the bottom on corporate tax rather than simply ratify the status quo. It must involve the governments of developing countries from the beginning.

Currently many governments work against their country's overall interests by lowering tax rates and granting tax exemptions in a battle to attract capital. This ends up harming all nations except for a few tax havens, effectively leaving billions of public wealth in private hands. ${ }^{442}$ Developing country governments lose a lot of money to unnecessary tax exemptions given to corporations. ${ }^{443}$

Governments are doing relatively better at fighting tax dodging by individuals. They have started to cooperate with each other against bank secrecy and anonymous shell companies. Most tax authorities now automatically exchange bank account data with each other. An increasing number of countries collect the names of the physical persons owning corporations ('beneficial owners'); such information will be made public in the EU, and the UK Parliament has passed legislation requiring its Overseas Territories - including well-known tax havens such as Bermuda and the British Virgin Islands - to implement public registers of beneficial ownership. However, scandals like the Panama Papers and Paradise Papers show the scale of the problem and how far it is from
'My message is for tax avoiders... if they don't pay taxes, how will the public sector be run? Who will pay for those who are poorer? If they have money to go to private clinics and doctors, saying that public sector services are bad, it is because they contributed to ruining it. - Dr Dorra Bousnina Lassoued, Head of Department of Preventive and Social Medicine and National Coordinator of Maternal, Child and Adolescent Health since March 2015 at the Ministry of Health, Tunisia 
being fixed. A lot of cracks remain in the system: there is still little transparency around corporate tax dodging, tax planners are inventing new ways to hide personal wealth, and tax dodgers have little to fear from those governments that are either unwilling or lack the capacity to prosecute them. Despite this, recent progress shows that where there is a will, there is a way.

\section{How tax policies can reduce gender inequality}

Tax policies have the potential not only to reduce the gap between rich and poor, but also to decrease inequality between women and men. Yet the current global tax system is shifting the burden to the poorest individuals and households. The majority of those affected are women, who have very little opportunity to influence tax policy or hold government to account.

Cuts to taxes for corporations, high earners and the wealthy disproportionately benefit men, as they dominate the corporate world. Men control over $86 \%$ of all companies in the world; ${ }^{444}$ hold more resources than women, are more likely to be at the top of the income ladder, and own more wealth than women.

These tax cuts have been accompanied by tax policies that often have a greater negative impact on poor women. VAT takes a larger proportion of income from those who are least able to pay - often women and femaleheaded households - especially in countries where basic food items are not exempted. ${ }^{445}$ Sanitary products are a necessity for women and girls, so VAT and import taxes on them can force the poorest women and girls to go without, undermining their education and employment opportunities and adding to stigma around menstruation.

Governments can budget to counter these issues, by considering:

- How revenues are raised and spent.

- Who takes on the financial burden of taxation.

- How taxes are affecting social attitudes about the roles of men and women.

- How taxes are affecting people's lives; they can explore this by consulting poor citizens and women's rights organizations. ${ }^{446}$

Since 1995, because of gender-budgeting efforts, South Africa has reformed income taxes to reduce the higher tax rates on married women. VAT on kerosene was reduced to protect poor, particularly female-headed, households, who rely on it as an important source of fuel. However, in the last year overall VAT has been raised by $1 \%$, which will affect women the most. ${ }^{447}$ As a result of national campaigning efforts by tax justice activists, the government has now effectively eliminated VAT on sanitary products. $^{448}$ 


\section{CRACKING DOWN ON CORRUPTION}

Tackling corruption is central to achieving universal public services and social protection.

Corruption itself impacts on inequality in different ways. At the most basic level, the poorest people are more likely to have to pay bribes. ${ }^{449}$ One study in Mexico found that the police are more likely to demand bribes from poor people, because the richest people are more willing and able to retaliate. ${ }^{450}$ Bribes represent a much higher proportion of the incomes of the poorest households, which means they contribute to increasing income inequality. ${ }^{451}$

Women can often have less power and voice to demand accountability, making them easier targets for corruption. Women are more likely than men to identify corruption as having a negative impact on their daily lives. ${ }^{452}$ Women are more likely to be users of public services and social protection, because of social attitudes that see them as the primary caretakers of their families, meaning they are often more exposed to corruption in service delivery. ${ }^{453}$

Arguably the greatest adverse impact on inequality and poverty is made by 'grand corruption' - the large-scale looting of state resources and organized influence on state actions by elites. This affects inequality directly by enabling the richest to pay less tax than they should, and indirectly by reducing government revenue and spending which could be used to tackle inequality.

Corruption is also a global phenomenon, often fuelled by the failure of rich nations to regulate their financial sectors adequately. ${ }^{454}$ The global system of tax havens facilitates this on an industrial scale. For example, the intergovernmental Financial Action Task Force found that tax havens were strongly involved in facilitating corruption. ${ }^{455}$ Ordinary citizens are less likely to want to pay their taxes if they feel that those at the top do not pay their fair share, and that the tax money they pay will not be well spent. ${ }^{456}$

The illegal depletion of state resources through corruption means there is less money available for education, health and other public services and social protection. In the Dominican Republic in 2017, for example, Oxfam has shown that corruption was depriving the state of enough revenues to double health spending. ${ }^{457}$

\section{THE ROLE OF INTERNATIONAL AID}

Even if they grow strongly and improve tax collection, 48 countries still lack the domestic resources to fund universal health, education and social protection, and would need an extra $\$ 150 \mathrm{bn}$ to meet these needs. ${ }^{458}$ These countries simply cannot afford to eradicate poverty, even when equipped with progressive policies. 
Tackling extreme poverty in these countries will rely not only on domestic taxes, but also on development aid. ${ }^{459}$ Aid can support underfunded health, education and social protection systems without increasing recipients' fiscal deficits. In a world of plenty, in which OECD countries boast per capita income that is 52 times higher than in low-income countries, ${ }^{460}$ aid serves as an immediate redistribution of resources from richer to poorer countries. Aid is not charity; it is a matter of justice, since the wealth of the richest countries is borne of historical ${ }^{461}$ and ongoing exploitation of the developing world. ${ }^{462}$ It is also an expression of solidarity that transcends borders.

Aid has enormous potential to reduce inequality both between and within countries - but only if it is scaled up and given the right way. ${ }^{463}$

On average, OECD donor countries provide $0.31 \%$ of their gross national income (GNI) to poor countries ( $\$ 147 \mathrm{bn}$ in 2017 ), far short of the $0.7 \%$ promise they made nearly 50 years ago. ${ }^{464}$ Only five countries are living up to this promise. ${ }^{465}$ If the other OECD donor countries followed through on their commitment, an extra $\$ 1.5$ trillion could be raised by $2030 .{ }^{466}$ Rich countries should not only give more aid, they should also better target it to countries with the least resources to tackle extreme poverty. ${ }^{467}$

\section{Box 11: Aid for education}

Since the Dakar World Education Forum in 2000, at which donors committed to increase aid to achieve basic quality education for all, 34 million more children have attended school in low- and middle-income countries. ${ }^{468}$ Thanks to multilateral funding through the Global Partnership for Education, 238,000 teachers were trained in 2016, up from around 98,000 in 2014.469 Together these investments have made significant strides in getting more girls into school, ${ }^{470}$ tackling gender inequality as well as poverty.

Unfortunately, in recent years, aid to health and education has been stagnating: aid spending on health ( $\$ 21 \mathrm{bn}$ in 2016 ) has stalled since 2013 (after a 250\% increase between 2002 and 2013), and aid spending on education ( $\$ 12 \mathrm{bn}$ in 2016 ) has also remained fairly static, only rising by $6 \%$ in real terms between 2010 and $2016 .{ }^{471}$ Aid is also being used to support discredited PPPs, as described in section 3. Aid devoted to social protection is very small, at $\$ 2.3 \mathrm{bn} .{ }^{472}$

Aid can also reduce inequality by supporting governments to collect more taxes - and to collect them more equitably. This is key to charting a path towards a future in which aid is no longer needed. An increase in taxation and other domestic revenues of an extra $2 \%$ of GDP by 2020 would add $\$ 144$ bn more to low-income and lower-middle-income countries' coffers the equivalent of total aid in 2017. Unfortunately, aid targeted at helping governments raise more domestic revenue is just $0.18 \%$ of total aid, and donors are not on track to meet their commitments to double this amount by 2020 under the Addis Tax Initiative. ${ }^{473}$

Aid can also play a key role supporting citizens to hold governments to account, and particularly aid to women's rights organizations. ${ }^{474}$ This 
support remains very inadequate. In $2015-16$, only $\$ 225 m$ on average per year was committed to non-governmental women's organizations and only $\$ 38 \mathrm{~m}$ of that went directly to organizations based in developing countries. ${ }^{475}$

\section{THE THREAT OF DEBT}

More and more governments are facing rapid increases in their levels of debt, especially in Africa. Faced with essential development needs and insufficient aid and domestic revenues, many developing country governments have borrowed to fund their development. ${ }^{476}$ Kenya, for example, is now spending almost $50 \%$ of its revenues on debt repayments. ${ }^{477}$ Over the past six years, sub-Saharan governments have issued $\$ 81 \mathrm{bn}$ in dollar bonds to investors looking for high yields. ${ }^{478}$

On top of this are more opaque loans from bilateral governments such as China and India, as well as OECD-based commercial lenders. ${ }^{479}$ The large amount of private and short-term debt makes these countries vulnerable to changing financial conditions. According to the IMF, 23 countries are either in debt distress or at high risk of suffering a debt crisis - most of them are in sub-Saharan Africa. ${ }^{480}$ In 2012, Zambia was borrowing at lower interest than Spain; it is now paying $16 \%$ interest. ${ }^{481}$

Many developing countries are now facing major problems servicing their debts and are having to make tough choices about revenues and spending, often under pressure from the IMF. ${ }^{482}$ In such cases, making decisions about which taxes to raise and what spending to cut, and the impact that this will have on rich and poor people and on men and women, is critical. The IMF has committed to supporting countries to tackle inequality, which is very positive, but Oxfam's research shows that so far there has been little evidence of this happening. ${ }^{483}$ There is also virtually no effort being made to reduce debt burdens through restructuring and cancellation, and thereby to cut the amount of funds that are being diverted away from social spending. A new wave of IMF bailouts will be an opportunity for the IMF to put its words into action and support countries to make the economic choices that reduce inequality. Too many countries are continuing to balance their books at the expense of poor women and men. ${ }^{484}$ This undermines countries' capacity to tackle inequality. History shows that without a new approach that centres on taxing those most able to pay, these economic programmes will hit the poorest women and men hardest. ${ }^{485}$

Government borrowing is of course not all bad, and if it is sustainable and invested well it can reduce inequality, not increase it. But often much of this lending is for projects of dubious value, the costs of which are often heavily inflated, fuelling corruption and capital flight. ${ }^{486}$ Much of this debt is linked to poorly conceived PPPs. ${ }^{487}$

Rapid global action is required to tackle this problem before it spirals out of control. A combination of financing, rescheduling and debt cancellation will have to be put in place so that reckless creditors take their share of the burden. Choices around fiscal austerity must focus on raising taxes 
from the richest individuals and corporations as well as cutting down on corruption and waste, not on raising taxes and cutting services to poor people. An independent debt restructuring and arbitration mechanism should be created to provide a safe and neutral negotiation space that protects debtor countries' poor citizens. This should be combined with a major increase in foreign aid so that countries are able to invest in fighting inequality without borrowing from future generations. 


\section{FIGHTING FOR A FAIRER WORLD}

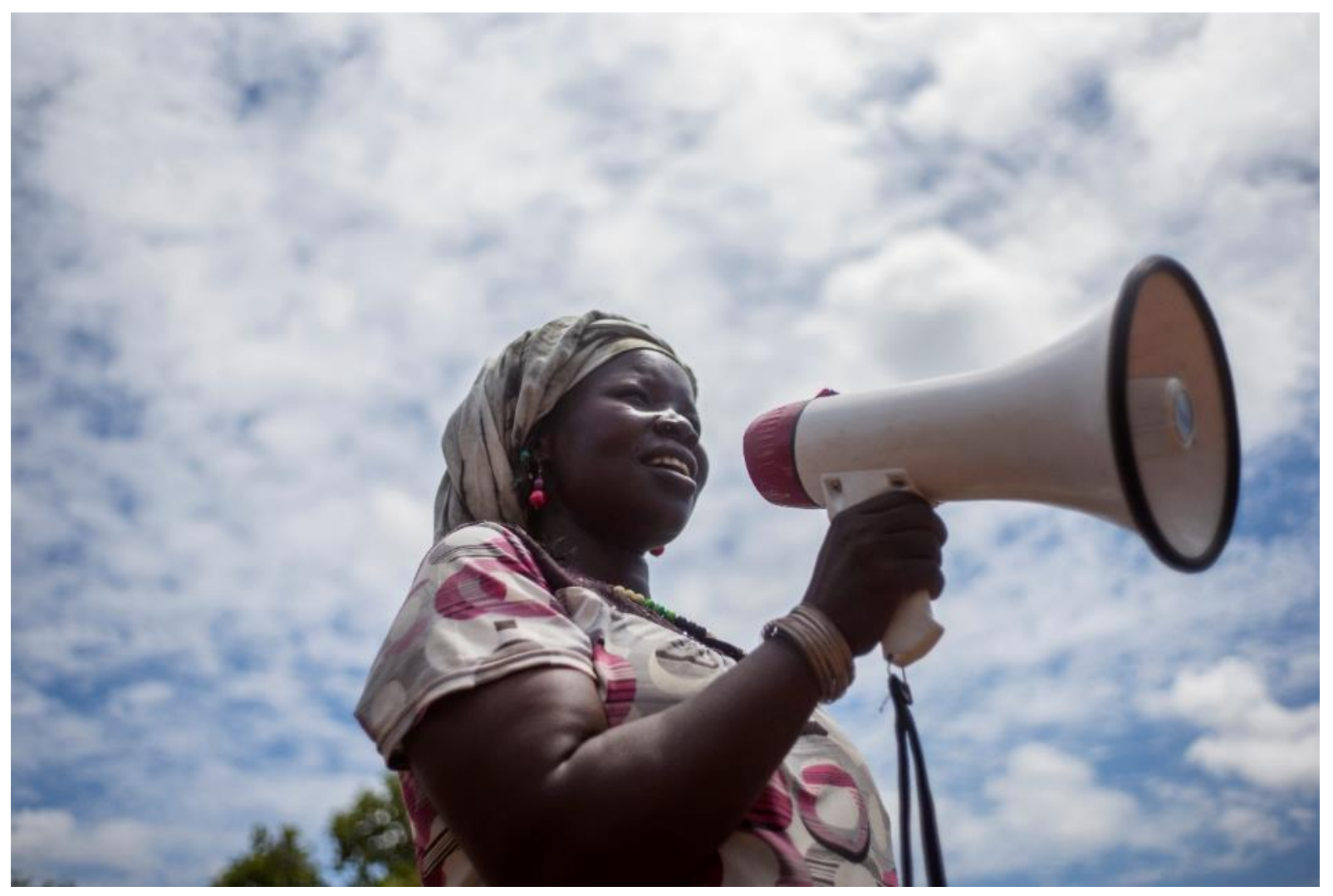

Sarah, a refugee from South Sudan living in Uganda, calls for women to join her handicrafts group in Bidibidi Settlement. With the help of Oxfam and partner CEFORD, the group was established to enable women to earn an income and socialize. Sarah had a jewellery business back home in South Sudan, but she fled the country after her husband was killed in the street in front of her. The group has given her the opportunity to earn money, but also to share her experiences with other women in the settlement. Photo: Kieran Doherty/Oxfam.

- Only people power can force our leaders to reduce the gap between rich and poor.

- A growing global movement, the Fight Inequality Alliance, is joining up struggles around the world against inequality.

The policies needed to reduce inequality are clear, including the provision of universal public services and social protection, paid for by taxation of the richest people and corporations. In too many countries, the reason these policies are not being implemented is because political leaders listen to elites and not to the demands of ordinary people. The more organized and vocal ordinary citizens are, the greater the opportunity to change this. In the 2000s, Latin America saw a dramatic decline in the level of income inequality, with governments raising taxes on the richest, increasing minimum wages, and investing in health, education and other public services. A major driving factor behind this was the power of ordinary people coming together to demand change. ${ }^{488}$ 


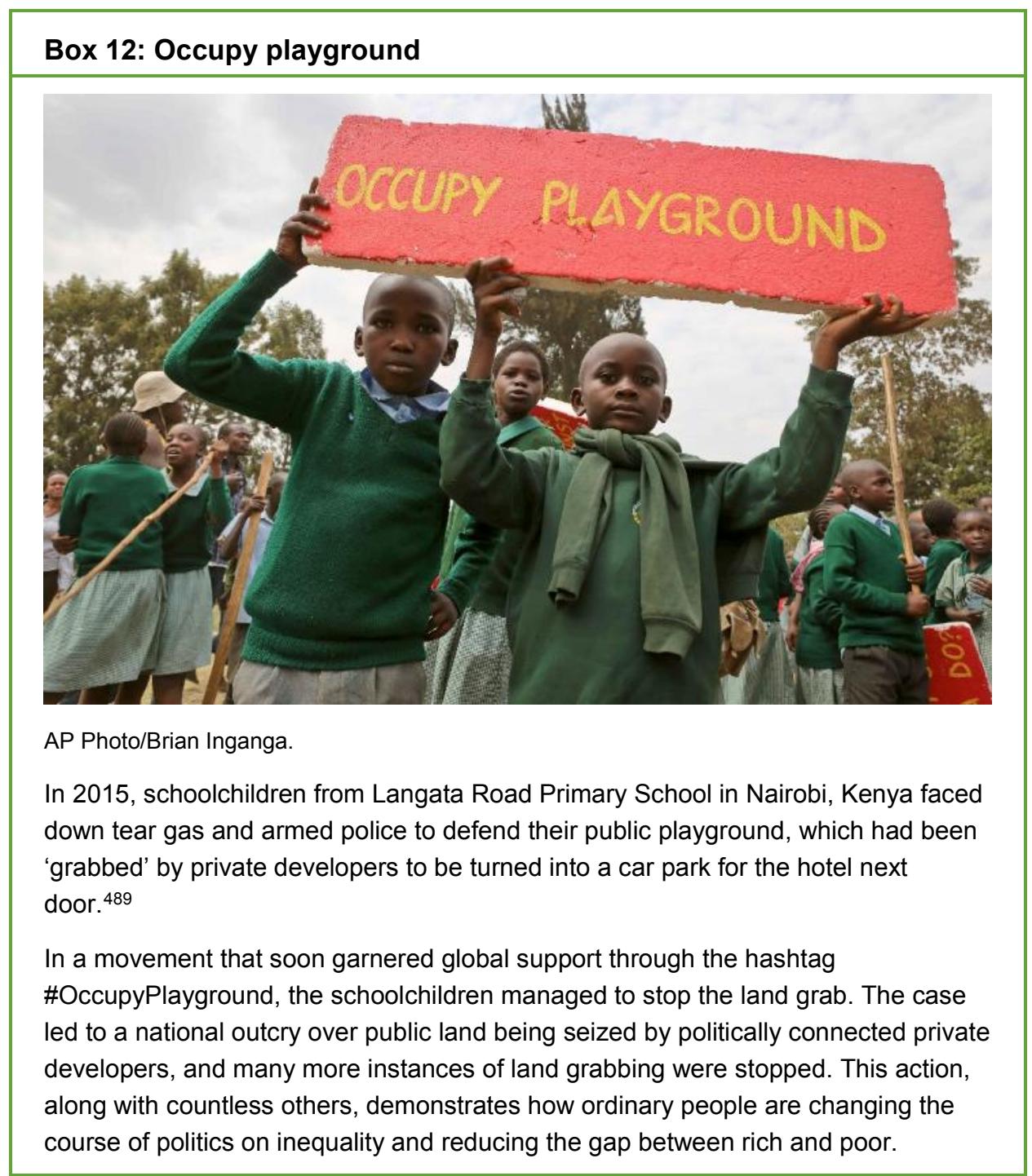

This trend of increasing activism is reflected in a growing women's movement as seen in \#metoo and the Women's March. In Latin America, this has inspired thousands of women to act, especially through Ni Una Menos ('Not One Less'). ${ }^{490}$ Born in Argentina in 2015 as a national campaign to combat the murder of women, it has become a movement across the whole region. Through collective action, Ni Una Menos has transformed national debate and catalysed change globally, as seen with the campaign's leadership of the 2018 Women's Strike. ${ }^{491}$

The emergence of the Fight Inequality Alliance, ${ }^{492}$ which brings together national struggles for greater equality, is central to building a global movement of ordinary people determined to fight together for a fairer world. In the same way that the civil rights movement disturbed the sediment of established norms 50 years ago, this generation is proving that it has the power to determine how governments act, and is calling on them to put an end to poverty and inequality.
'Fighting inequality is a must for being human.' - Lamees Farraj, AMAN: Coalition for Integrity and Accountability, Occupied Palestinian Territory (OPT) 


\section{Governments must act to fight inequality}

Governments must listen to ordinary citizens and take meaningful action to reduce inequality. All governments must: set concrete, timebound targets and action plans to reduce inequality as part of their commitments under Sustainable Development Goal (SDG) 10 on inequality. These plans should include action in the following three areas:

1. Deliver universal free health care, education and other public services that also work for women and girls. Stop supporting privatization of public services. Provide pensions, child benefits and other social protection for all. Design all services to ensure they also deliver for women and girls.

2. Free up women's time by easing the millions of unpaid hours they spend every day caring for their families and homes. Let those who do this essential work have a say in budget decisions and make freeing up women's time a key objective of government spending. Invest in public services including water, electricity and childcare that reduce the time needed to do this unpaid work.

Design all public services in a way that works for those with little time to spare.

3. End the under taxation of rich individuals and corporations. Tax wealth and capital at fairer levels. Stop the race to the bottom on personal income and corporate taxes. Eliminate tax avoidance and evasion by corporates and the super-rich. Agree a new set of global rules and institutions to fundamentally redesign the tax system to make it fair, with developing countries having an equal seat at the table. 
All links last accessed October 2018, unless otherwise specified.

1 Forbes. (2018). The World's Billionaires. https://www.forbes.com/billionaires/list/; and P. Espinoza Revollo et al. (2019). Public Good or Private Wealth? Methodology Note. http://dx.doi.org/10.21201/2019.3651

2 World Bank. (2018a). Poverty and Shared Prosperity. http://www.worldbank.org/en/publication/poverty-and-shared-prosperity

3 A. Shorrocks, J. Davies and R. Lluberas. (2018). World Wealth Report 2018. Credit Suisse. https://www.credit-suisse.com/corporate/en/research/research-institute/globalwealth-report.html

4 N. Lustig. (2015). The Redistributive Impact of Government Spending on Education and Health: Evidence from 13 Developing Countries in the Commitment to Equity Project. https://www.imf.org/en/Publications/Books/lssues/2018/02/26/Inequality-and-FiscalPolicy-42811

5 P. Espinoza Revollo et al. (2019). Public Good or Private Wealth? Methodology Note, op cit.

6 M. Hanrahan. (2012, May 18). Antilia: Inside Mukesh Ambani's 27-Story Mumbai Residence, The World's First \$1 Billion Home (PHOTOS). The Huffington Post. https://www.huffingtonpost.in/entry/antilia-inside-mukesh-expensive-homemumbai $\mathrm{n} 1527703$

7 M Döpfner. (2018). Jeff Bezos reveals what it's like to build an empire and become the richest man in the world - and why he's willing to spend $\$ 1$ billion a year to fund the most important mission of his life. Business Insider; Forbes. (2018). The World's Billionaires. https://www.forbes.com/billionaires/list/. For Ethiopian heath budget calculations see: P. Espinoza Revollo et al. (2019). Public Good or Private Wealth? Methodology Note. http://dx.doi.org/10.21201/2019.3651

8 J.D. Ostry, P. Loungani and A. Berg. (forthcoming). Confronting Inequality: How Societies Can Choose Inclusive Growth. Colombia.

9 Previous Oxfam reports have focused on other key factors in the fight against inequality. These include work and wages (reward work not wealth): https://www.oxfam.org/en/research/reward-work-not-wealth; redesigning our economic model (economy for 99\%): https://www.oxfam.org/en/research/economy-99; ending the capture of politics and economics by elites (economy for the $1 \%$ ): https://www.oxfam.org/en/research/economy-1

10 See, for example, J. Brumby and M. Keen. (2018, February 13). Game-Changers and Whistle-Blowers: Taxing Wealth. IMF. https://blogs.imf.org/2018/02/13/gamechangers-and-whistle-blowers-taxing-wealth/ and IMF (2017) Fiscal Monitor: Tackling Inequality, https://www.imf.org/en/Publications/FM/Issues/2017/10/05/fiscal-monitoroctober-2017 See also The Economist (2018, August 9) Overhaul tax for the 21st century, https://www.economist.com/leaders/2018/08/09/overhaul-tax-for-the-21stcentury

11 Oxfam calculations; see methodology note: P. Espinoza Ravollo et al. (2019). Public Good or Private Wealth? Methodology Note, op. cit.

12 lbid.

13 World Bank. (2018a). Poverty and Shared Prosperity 2018. http://www.worldbank.org/en/publication/poverty-and-shared-prosperity. Global extreme poverty declined on average by 1 percentage point per year between 1990 and 2015 , but only by 0.6 percentage points per year between 2013 and 2015, and by even less between 2015 and 2018.

14 lbid.

15 Ibid.

16 Standard Newspaper Kenya 2018 Double tragedy: Police woman loses twins, held in Nairobi West Hospital over Sh2.9 million bill. 
https://www.sde.co.ke/article/2001255156/double-tragedy-police-woman-loses-twinsheld-in-nairobi-west-hospital-over-sh2-9-million-bill

17 Ibid, p.24. The World Bank's projections show that at current rates of economic growth, extreme poverty will not be eradicated by 2030 unless inequality is reduced by making income of the bottom $40 \%$ of the population grow faster than that of the rest. Without inequality reduction, even with double rates of economic growth about $3.7 \%$ of the global population will be living in extreme poverty.

18 F. Alvaredo, L. Chancel, T. Piketty, E. Saez and G. Zucman. (2017). The World Inequality Report 2018. https://wir2018.wid.world/

19 UNESCO. (2017). Global Education Monitoring Report 2017/8. Accountability in Education: Meeting our Commitments. http://unesdoc.unesco.org/images/0025/002593/259338e.pdf

20 M. Kruk et al. (2018). Mortality due to low-quality health systems in the universal health coverage era: a systematic analysis of amenable deaths in 137 countries. https://www.thelancet.com/journals/lancet/article/PIIS0140-6736(18)31668-4/fulltext The Lancet (2018, November 17), Volume 392, Issue 10160, p.2203-2212: 3.6 million deaths were found to be due to lack of access to healthcare, or 9,863 per day.

$21 \mathrm{~L}$. Addati et al. (2018, June 28). Care work and care jobs for the future of decent work: International Labour Organization (ILO). Available at:

https://www.ilo.org/global/topics/care-economy/care-for-fow/lang--en/index.htm Figures are for 64 countries where time-use surveys were carried out, representing $66.9 \%$ of the world's population, so the overall global figure is likely to be significantly higher. Women were found to do on average $75 \%$ of unpaid care work.

22 In the 10 years since the financial crisis, the number of billionaires has risen from 1,125 in 2008 to 2,208 in 2018 . For more detail, please see methodology note: http://policy-practice.oxfam.org.uk/publications/private-wealth-or-public-good-620599

23 The total fortune of those who have remained in the Forbes list consistently between 2017 and 2018 (about 1,900) has increased by about $\$ 900 \mathrm{bn}$ in one year, which is equivalent to an increase of $\$ 2.5 \mathrm{bn}$ per day. For more detail, please see methodology note: http://policy-practice.oxfam.org.uk/publications/private-wealth-or-public-good620599

24 The world has more billionaires than ever before. Forbes list of billionaires (2018) expanded by 165 between 2017 and 2018. 316 new billionaires entered the list more than double the number who left the list, which was 151. For more detail, please see methodology note: http://policy-practice.oxfam.org.uk/publications/private-wealthor-public-good-620599

25 Oxfam calculations based on Forbes. (2018). The World's Billionaires, op. cit, and Credit Suisse. (2018). World Wealth Report Databook. For more detail, see methodology note: http://policy-practice.oxfam.org.uk/publications/private-wealth-orpublic-good-620599

26 Jeff Bezos' fortune in March 2018 was \$112bn. For Ethiopian Heath Budget calculations see: P. Espinoza Revollo et al. (2019). Public Good or Private Wealth? Methodology Note, op. cit.

27 McKinsey Global Institute. (2015). The Power of Parity. Available at: http://www.mckinsey.com/global-themes/employment-and-growth/how-advancingwomensequality-can-add-12-trillion-to-global-growth

28 Figure calculated based on Apple's reported annual revenue in 2017 (\$229.3bn). Available at: https://www.apple.com/newsroom/pdfs/fy17q4/Q4FY17ConsolidatedFinancialStatements.pdf

29 World Bank. (2018a). Poverty and Shared Prosperity, op cit.

30 P. Espinoza Revollo et al. (2019). Public Good or Private Wealth? Methodology Note, op cit.

31 K. Scheve and D. Stasavage. (2016). Taxing the Rich: A History of Tax Fairness in the United States and Europe. Princeton University Press. https://doi.org/10.1515/9781400880379 
32 Figures taken from Commitment to Reducing Inequality index database, figures are for 122 developing countries. Average top rate of personal income tax is $28.55 \%$.

33 INESC. (2015). 'Mineração e (in)justiça tributária no Brasil'. Nota Técnica 184.

34 Office for National Statistics. (2018). Effects of taxes and benefits on household income - Financial year ending 2017.

https://www.ons.gov.uk/peoplepopulationandcommunity/personalandhouseholdfinanc es/incomeandwealth/datasets/theeffectsoftaxesandbenefitsonhouseholdincomefinanci alyearending2014, Table 14: Average incomes, taxes and benefits by decile groups of ALL households (ranked by unadjusted disposable income), 2016/17.

35 P. Espinoza Revollo et al. (2019). Public Good or Private Wealth? Methodology Note, op. cit.

36 G. Zucman. (2015). The Hidden Wealth of Nations. Chicago University Press. https://doi.org/10.7208/chicago/9780226245560.001.0001; See methodology note for an explanation of workings: https://doi.org/10.21201/2017.1350. A. Alstadsaeter, J. Niels and G. Zucman. (2017). Tax Evasion and Inequality. https://doi.org/10.3386/w23772

37 A. Alstadsaeter et al. (2017). Tax Evasion and Inequality, ibid.

38 Oxfam calculations based on OECD data available for 35 OECD and 43 non-OECD countries for 2015 (unweighted averages). OECD Stat. Revenue Statistics - OECD countries: Comparative tables. https://stats.oecd.org/viewhtml.aspx?datasetcode=REV\&lang=en

39 G. Zucman. (2015). The Hidden Wealth of Nations, op cit. See the methodology note for Oxfam's 2018 Davos report for an explanation of workings: D. Hardoon et al. (2018). Reward Work, Not Wealth. Methodology Note, op cit.

40 Djafffar Salchi. Private correspondence with author.

41 Civicus. (2018). The State of Civil Society Report. https://www.civicus.org/index.php/state-of-civil-society-report-2018

42 Council on Foreign Relations. (2017, February 23). Inequality and the rise of Authoritarianism. Transcript of panel featuring J.A. Goldstone, K.R. McNamara and S. Hamid. https://www.cfr.org/event/inequality-and-rise-authoritarianism

43 E.D. Gould and A. Hijzen. (2016). Growing Apart, Losing Trust? The Impact of Inequality on Social Capital, IMF Working Paper WP/16/176. https://www.imf.org/external/pubs/ft/wp/2016/wp16176.pdf

44 P. Fajnzylber, D. Lederman and N. Loayza. (2002). Inequality and Violent Crime. Journal of Law and Economics, 45(1):1-40. https://doi.org/10.1086/338347; R. Wilkinson and K. Pickett. (2009). The Spirit Level. London: Penguin.

45 R. Wilkinson and K. Pickett. (2018). The Inner Level. London: Penguin.

46 M. Chang. (2015). Women and Wealth: Insights for grantmakers. Asset Funders Network. https://www.mariko-chang.com/AFN Women and Wealth Brief 2015.pdf

47 IMF. (2018). Pursuing Women's Economic Empowerment. https://www.imf.org/en/Publications/PolicyPapers/Issues/2018/05/31/pp053118pursuing-womens-economic-empowerment

48 Of the 2,208 billionaires on the Forbes list, only $244(11 \%)$ are women. Globally, men are estimated to own $60 \%$ of wealth. See: A. Shorrocks, J. Davies and R. Lluberas. (2018). World Wealth Report 2018. Credit Suisse. https://www.creditsuisse.com/corporate/en/research/research-institute/global-wealth-report.html

49 UN Women. (2018). Turning Promises Into Action: Gender equality in the 2030 Agenda For Sustainable Development. http://www.unwomen.org//media/headquarters/attachments/sections/library/publications/2018/sdg-reportgender-equality-in-the-2030-agenda-for-sustainable-development-2018en.pdf?la $=$ en\&vs $=5653$

50 This stat is based on the Credit Suisse estimates of men's and women's share of global wealth in the Global Wealth Report 2018 (op cit). The 50\% represents the percent rather than percentage point difference. 
51 McKinsey Global Institute. (2015). The Power of Parity. op. cit.

52 Figure calculated based on Apple's reported annual revenue in 2017 (\$229.3bn). Available at: https://www.apple.com/newsroom/pdfs/fy17q4/Q4FY17ConsolidatedFinancialStatements.pdf

53 A. Langer et al. (2015). Women and Health: the key for sustainable development. The Lancet, 386(9999): 1165-210. https://doi.org/10.1016/S0140-6736(15)60497-4

B. Heilman et al. (2017). State of the World's Fathers: Time for Action. Promundo, Sonke Gender Justice, Save the Children and MenEngage Alliance. https://sowf.mencare.org/

54 Figure calculated based on Apple's reported annual revenue in 2017 (\$229.3bn). Available at: https://www.apple.com/newsroom/pdfs/fy17q4/Q4FY17ConsolidatedFinancialStatements.pdf

55 Figures taken from Kenya Demographic and Health Survey 2014, tables 3.2.1 and 3.2.2. Only $0.4 \%$ of young women from the lowest wealth quintile continue their education beyond secondary level, compared to $35.7 \%$ of young men from the richest wealth quintile. Kenya National Bureau of Statistics. (2015). Kenya Demographic and Health Survey 2014. https://dhsprogram.com/pubs/pdf/fr308/fr308.pdf

56 Figures taken from Kenya Demographic and Health Survey 2014, op. cit. A child from the wealthiest quintile has on average 11.78 years of education, compared to 6.15 for a child from the poorest quintile.

57 R. Wilkinson and K. Pickett. (2009). The Spirit Level. op. cit.; and J. Davis and B. Mazumder. (2017). The Decline in Inter-Generational Mobility after 1980. Opportunity and Inclusive Growth Institute Working Paper 17-21. https://www.minneapolisfed.org/institute/working-papers/17-21.pdf

58 Ministry of Health - MOH/Nepal, New ERA/Nepal and ICF. (2017). Nepal Demographic and Health Survey 2016, op cit. Tables 8.3, 3.3.1. and 3.3.2. Under-five mortality for the poorest quintile is 62 deaths per 1,000 compared to 24 deaths per 1,000 for the richest quintile.

59 Ministry of Health - MOH/Nepal, New ERA/Nepal and ICF. (2017). Nepal Demographic and Health Survey 2016. Available at:

https://dhsprogram.com/publications/publication-fr336-dhs-final-reports.cfm. Tables 8.3, 3.3.1. and 3.3.2. Under-five mortality for the poorest quintile is 62 deaths per 1,000 compared to 24 deaths per 1,000 for the richest quintile.

60 From remarks made by Dr Martin Luther King in Chicago on the night of Friday, March 25th, 1966 https://quoteinvestigator.com/2015/10/22/mlk-health/

61 UN Women. (2018). Turning Promises Into Action. op. cit.

62 Office for National Statistics. (2014). Life Expectancy at Birth and at Age 65 by Local Areas in the United Kingdom: 2006-08 to 2010-12. https://www.ons.gov.uk/peoplepopulationandcommunity/birthsdeathsandmarriages/life expectancies/bulletins/lifeexpectancyatbirthandatage65bylocalareasintheunitedkingdo m/2014-04-16\#animated-maps-and-reference-tables. Life expectancy in Barking and Dagenham is 77.5 years. In Kensington and Chelsea it is 83.7 years.

63 Rede Nossa São Paulo. (2017). Mapa das Desigualdades de São Paulo 2016. Available at: https://www.nossasaopaulo.org.br/arqs/mapa-da-desigualdadecompleto-2016.pdf?v=1

64 J.D. Ostry et al. (forthcoming). Confronting Inequality. op. cit.

65 P. Espinoza Ravollo et al. (2019). Public Good or Private Wealth? Methodology Note, op cit.

66 From 1970 to 2009. J. Martinez-Vazquez and B. Moreno-Dodson. (2014). The Impact of Tax and Expenditure Policies on Income Distribution: Evidence from a Large Panel of Countries. Georgia State University.

67 N. Lustig. (2015). The Redistributive Impact of Government Spending on Education and Health, Evidence from 13 Developing Countries in the Commitment to Equity Project, op cit. 
68 GPE Secretariat. (2016). 5 ways education can help end extreme poverty. https://www.globalpartnership.org/blog/5-ways-education-can-help-end-extremepoverty

69 IMF. (2017). Fiscal Monitor: Tackling Inequality, IMF https://www.imf.org/en/Publications/FM/Issues/2017/10/05/fiscal-monitor-october$\underline{2017}$

70 K.E.M. Uslaner and M. Brown. (2005). Inequality, Trust, And Civic Engagement. American Politics Research, Volume 33. https://doi.org/10.1177/1532673X04271903

71 R. Wilkinson and K. Pickett. (2009). The Spirit Level. op. cit. and Z. Yu and F. Wang. (2017). Income Inequality and Happiness: An Inverted U-shaped Curve. Front. Psychol. https://doi.org/10.3389/fpsyg.2017.02052

72 See, for example: I. Illkkaracan, K. Kim and T. Kaya. (2015). The Impact of Public Investment in Social Care Services on Employment, Gender Equality, and Poverty: The Turkish Case. Istanbul Technical University Women's Studies Center in Science, Engineering and Technology and The Levy Economics Institute.

http://www.levyinstitute.org/pubs/rpr 8 15.pdf; and Q. Wodon, C. Montenegro, $\mathrm{H}$. Nguyen and A. Onagoruwa. (2018). Missed Opportunities: The high cost of not educating girls. World Bank. https://doi.org/10.1596/29956

73 Ibid.

74 Ibid.

75 See, for example, Medanta Hospital: https://www.medanta.org/

76 ICICI Securities Ltd. (2017). World class health infra at competitive prices to fuel Indian medical tourism boom. http://content.icicidirect.com/mailimages/MedicalTourismFeb17.htm

77 The Indian states of Uttar Pradesh and Chhattisgarh have an infant mortality rate of 64 deaths per 1,000 live births and 54 deaths per 1,000 live births respectively, higher than the sub-Saharan Africa (52 per 1,000 live births). India National Family Health Survey 2015-16. http://microdata.worldbank.org/index.php/catalog/2949 African figure from https://data.worldbank.org/indicator/SP.DYN.IMRT.IN?locations=RW-ZG

78 WHO/UNICEF. (2015). Progress on sanitation and drinking water, 2015 update and MDG assessment. https://www.who.int/water sanitation health/monitoring/imp-2015key-facts/en/

79 The World Bank. (2018). World Development Report 2018 - LEARNING to Realize Education's Promise. http://www.worldbank.org/en/publication/wdr2018

80 Globally, the number of deaths of children under five years of age fell from 12.7 million in 1990 to 6.3 million in 2013. See UNICEF, WHO, World Bank Group and UN. (2017). Levels and Trends in Child Mortality. https://data.unicef.org/resources/levelstrends-child-mortality-2017/

81 The World Bank. (2018). World Development Report 2018. op. cit. http://www.worldbank.org/en/publication/wdr2018

82 M. Kruk et al. (2018). Mortality due to low-quality health systems in the universal health coverage era. op. cit.

83 F. Chao, D. You, J. Pedersen, L. Hug and L. Alkema. (2018). National and regional under-5 mortality rate by economic status for low-income and middle-income countries: a systematic assessment. Lancet Global Health, 6(5):535-47. https://doi.org/10.1016/S2214-109X(18)30059-7

84 V. Esquival and A. Kaufmann. (2017). Innovations in Care: New Concepts, New Actors, New Policies. Friedrick-Ebert-Stiftung. http://library.fes.de/pdffiles/iez/13282.pdf

85 See, for example, World Bank. (2003). World Development Report 2004: Making Services Work for Poor People. https://openknowledge.worldbank.org/handle/10986/5986

86 IMF. (2017). Fiscal Monitor: Tackling Inequality. op. cit. and C. Mariotti et al. (2017). Great expectations: is the IMF turning words into action on inequality? 
https://www.oxfam.org/en/research/great-expectations-imf-turning-words-actioninequality. Oxfam International.

87 World Bank. (2003) Making Services Work for Poor People. op. cit. p.38-39

88 B. Emmett. (2007). In the Public Interest. Oxfam campaign report. https://policypractice.oxfam.org.uk/publications/in-the-public-interest-health-education-and-waterand-sanitation-for-all-112528

89 Barker 1944 in S. Van de Walle and Z. Scott. (2009). The role of public services in State and Nation-building: Exploring lessons from European History for Fragile States

90 Analysis by Development Pathways from Indonesia's National Socio-Economic Survey (SUSENAS) 2015

91 World Health Organization and World Bank. (2017). Tracking Universal Health Coverage: 2017 Global Monitoring Report. http://www.who.int/healthinfo/universal health coverage/report/2017/en/

92 R. Yates. (2017). Hospitals That Act as Modern-day Debtor Prisons Deny Rights and Dignity. Chatham House. https://www.chathamhouse.org/expert/comment/hospitalsact-modern-day-debtor-prisons-deny-rights-and-dignity

93 Ibid.

94 UNESCO. (2015a). Education For All 2000-2015: Achievements and challenges. https://en.unesco.org/gem-report/report/2015/education-all-2000-2015-achievementsand-challenges

95 R.B. Kattan and N. Burnett. (2004). User Fees In Primary Education. http://siteresources.worldbank.org/EDUCATION/Resources/2782001099079877269/547664-1099079993288/EFAcase userfees.pdf; The World Bank and P. Nanda. (2002). Gender Dimensions Of User Fees: Implications For Women's Utilization Of Health Care. Reproductive Health Matters, 10(20):127-34. https://doi.org/10.1016/S0968-8080(02)00083-6

96 P. Espinoza Revollo et al. (2019). Public Good or Private Wealth? Methodology Note. Oxfam, op. cit.; A. Marriott. (2009). Blind Optimism: Challenging the myths about private healthcare in poor countries. Oxfam. https://policypractice.oxfam.org.uk/publications/blind-optimism-challenging-the-myths-aboutprivate-health-care-in-poor-countries-114093; and B. Emmett. (2007). In the Public Interest. Oxfam Campaign Report. https://policy-practice.oxfam.org.uk/publications/inthe-public-interest-health-education-and-water-and-sanitation-for-all-112528

97 P. Espinoza Revollo et al. (2019). Ibid.

98 Own calculations based on the World Bank's World Development Indicators (WDI) database. GDP per capita figures for Thailand were rebased from 2011 purchasing power parity (PPP) \$ to 1990 PPP \$. This was done by multiplying each value of the real GDP in 2011 PPP $\$$ by the ratio of the 2011 GDP per capita in 2011 PPP $\$$ to the 2011 GDP per capita in current $\$$. Note, this is only an approximation to the ideal real GDP per capita in 1990 PPP \$. US GDP figures taken from J. Bolt, M. Timmer and J. Luiten van Zanden. (2014). GDP per capita since 1820. OECD. https://www.oecdilibrary.org/economics/how-was-life/gdp-per-capita-since-1820 9789264214262-7-en P. Espinoza Revollo et al. (2019). Public Good or Private Wealth? Methodology Note, op. cit.

99 V. Tangcharoensathien, W. Witthayapipopsakul, W. Panichkriangkrai, W. Patcharanarumol and A. Mills. (2018). Health systems development in Thailand: a solid platform for successful implementation of universal health coverage. The Lancet, 391(10126):1205-23. https://doi.org/10.1016/S0140-6736(18)30198-3

100 Netherlands Embassy in Bangkok. (2018). Life Sciences and Health in Thailand. Ministry of Foreign Affairs. https://www.netherlandsworldwide.nl/binaries/ennederlandwereldwijd/documents/publications/2018/04/18/factsheet-life-sciences-health-in-thailand/Thailand+-+Factsheet+Life+Sciences+\%26+Health.pdf

101 V. Tangcharoensathien et al. (2018). Health Systems Development in Thailand. op. cit. 
102 See, for example, H. Patrinos et al. (2009). The role and impact of public private partnerships in education. World Bank. https://ppp.worldbank.org/public-privatepartnership/library/role-and-impact-public-private-partnerships-education

103 M. Afridi. (2018). Equity and Quality in an education public private partnership. Oxfam Research Paper. https://www.oxfam.org/en/research/equity-and-qualityeducation-public-private-partnership-0 and A. Marriott. (2014). A Dangerous Diversion: Will the IFC flagship PPP bankrupt Lesotho's Ministry of Health. Oxfam Briefing Note. https://www.oxfam.org/sites/www.oxfam.org/files/bn-dangerousdiversion-lesotho-health-ppp-070414-en.pdf

104 See, for example, Eurodad. (2018). History RePPPeated: How Public Private Partnerships are Failing. https://eurodad.org/HistoryRePPPeated and A. Marriott. (2014). A Dangerous Diversion. op. cit.

105 T.C. Irwin. (2018, October 16). How to Control the Fiscal Costs of Public-Private Partnerships. International Monetary Fund (IMF) How To Notes. Available at: https://www.imf.org/en/Publications/Fiscal-Affairs-Department-How-ToNotes/Issues/2018/10/17/How-to-Control-the-Fiscal-Costs-of-Public-PrivatePartnerships-46294

106 CAICC. (2012). O Distrito como Pólo de Desenvolvimento: Um Olhar da Sociedade Civil. https://www.caicc.org.mz/index.php/biblioteca/governacao/3039-o-distrito-comopolo-de-desenvolvimento-um-olhar-da-sociedade-civil

107 It is an explicit goal of the WB-funded programme 'to expand outreach of the Punjab Education Fund (PEF) to 2.8 million out-of-school children'. World Bank. (2016). Third Punjab Education Sector Project. Project Appraisal Document. http://documents.worldbank.org/curated/en/967701468198234577/pdf/PAD1641PAD-P154524-R2016-0090-1-Box394887B-OUO-9.pdf

108 M. Afridi. (2018). Equity and Quality in an education public private partnership. op. cit.

109 Taken from interview with the Guardian newspaper, 18 September 2018. Bill Gates: 'Trump is open-minded' - video. https://www.theguardian.com/globaldevelopment/video/2018/sep/18/bill-gates-interview-donald-trump-video

110 K. Scheve and D. Stasavage. (2016). Taxing the Rich. op. cit. for personal income tax and inheritance tax; and Tax Foundation for corporate income tax: https://github.com/TaxFoundation/data/blob/master/OECD-corporate-income-taxrates/OECD corp income tax rates 1981-2015.csv\#L1 Note: Sample of 20 rich countries. Average top rate of income tax for developing countries is $28 \%$ - Oxfam and DFI Commitment to Reducing Inequality index database.

111 See, for example, C. Dubay. (2010). The Case Against the Death Tax https://www.heritage.org/taxes/report/the-economic-case-against-the-death-tax and Kit Bond Quotes. https://www.brainyquote.com/quotes/kit_bond_348278, accessed December 6, 2018.

112 P. Espinoza Revollo et al. (2019). Public Good or Private Wealth? Methodology Note, op. cit.

113 Oxfam calculations based on OECD data available for 35 OECD and 43 non-OECD countries (unweighted averages): OECD Stat. Revenue Statistics - OECD countries: Comparative tables. https://stats.oecd.org/viewhtml.aspx?datasetcode=REV\&lang=en. Note: Payroll taxes include social security contributions and other taxes on salaries and wages. Taxes on goods and services include sales taxes and VAT.

114 Figures for decline in US tax rates taken from T. Piketty. (2014). Capital in the 21st Century. Cambridge: Harvard University Press. Data available at: https://ourworldindata.org/grapher/top-income-tax-rates-piketty

115 CEPAL. (2017). Panorama Fiscal de America Latina y El Caribe p. 47: https://repositorio.cepal.org/bitstream/handle/11362/41044/10/S1700069 es.pdf

116 Brazil INESC. (2015). 'Mineração e (in)justiça tributária no Brasil'. Nota Técnica 184, op cit. And UK Office for National Statistics (2018) Effects of taxes and benefits on household income. https://www.ons.gov.uk/peoplepopulationandcommunity/personalandhouseholdfinanc es/incomeandwealth/datasets/theeffectsoftaxesandbenefitsonhouseholdincomefinanci 
alyearending2014. Table 14: Average incomes, taxes and benefits by decile groups of ALL households (ranked by UNADJUSTED disposable income), 2016/17.

117 C. Isidore. (2013). Buffett says he's still paying lower tax rate than his secretary. CNN Money. https://money.cnn.com/2013/03/04/news/economy/buffett-secretarytaxes/index.html

118 G. Zucman. (2015). The Hidden Wealth of Nations. op. cit.; See the methodology note for Oxfam's 2018 Davos report for an explanation of workings: D. Hardoon et al. (2018). Reward Work, Not Wealth. Methodology Note.

http://dx.doi.org/10.21201/2017.1350; A. Alstadsaeter et al. (2017) Tax Evasion and Inequality. op. cit.

119 G. Zucman. (2015). The Hidden Wealth of Nations. op. cit.

120 Ibid.

121 United Nations Conference on Trade and Development (UNCTAD). (2015). World Investment Report 2015. http://unctad.org/en/PublicationsLibrary/wir2015 en.pdf. Other estimates of the cost of corporate tax dodging for developing countries range from \$47bn to \$200bn. E. Crivelli, R. De Mooij and M. Keen. (2015). Base Erosion, Profit Shifting and Developing Countries. IMF Working Paper, 15/118, https://www.imf.org/external/pubs/ft/wp/2015/wp15118.pdf; T.R. Tørsløv, L.S. Wier and G. Zucman. (2018, June 5). The Missing Profits of Nations. NBER Working Paper No. 24701. http://www.nber.org/papers/w24701. See in particular Appendix C.4d: http://gabriel-zucman.eu/files/TWZ2018Appendix.pdf. Estimates are for 2015.

122 IMF. (2017). Fiscal Monitor: Tackling Inequality. op. cit.

$123 \mathrm{Ibid}$. and The Economist. (2018, August 9). Overhaul tax for the 21st century. https://www.economist.com/leaders/2018/08/09/overhaul-tax-for-the-21st-century

124 J. Ostry, A. Berg and C. Tsangarides. (2014). Redistribution, Inequality and Growth. IMF. Staff Discussion Note SDN14/02. https://doi.org/10.5089/9781484352076.006

125 Oxfam calculations based on OECD data. https://stats.oecd.org/viewhtml.aspx?datasetcode=REV\&lang=en

126 KPMG. (2015). Colombia - New Tax Reform Introduces Wealth Tax for Individuals. https://home.kpmg.com/xx/en/home/insights/2015/03/flash-alert-2015-006.html

127 K. Scheve and D. Stasavage (2016) Taxing the Rich. op. cit.

128 Tax Foundation Data. https://github.com/TaxFoundation/data/blob/master/OECDcorporate-income-tax-rates/OECD corp income tax rates 1981-2015.csv\#L1

129 Source: P. Espinoza Revollo et al. (2019). Public Good or Private Wealth? Methodology Note, op cit.

130 M. Lawson and M. Martin. (2018). Commitment to Reducing Inequality index 2018. Oxfam and Development Finance International. www.inequalityindex.org and https://www.oxfam.org/en/research/commitment-reducing-inequality-index-2018. DOI: http://dx.doi.org/10.21201/2018.3415.

131 Tax Policy Center. (2017). Distributional Analysis on the Conference Agreement for the Tax Cuts and Jobs Act. https://www.taxpolicycenter.org/publications/distributionalanalysis-conference-agreement-tax-cuts-and-jobs-act

132 M. Lawson and M. Martin. (2018). Commitment to Reducing Inequality index 2018, op. cit.

133 C. Kim. (2017). Rich South Koreans, conglomerates face big tax bill as government seeks to fund welfare. Reuters. https://www.reuters.com/article/us-southkoreaeconomy-tax/rich-south-koreans-conglomerates-face-big-tax-bill-as-governmentseeks-to-fund-welfare-idUSKBN1AI0Z9; and Jo He-rim. (2017). Parliament passes 2018 government budget proposal. The Korea Herald. http://www.koreaherald.com/view.php?ud=20171205001033. Further planned increases in the minimum wage have been reduced in the face of fierce criticism from the business community, and to mitigate the short-term economic impact. President Moon is providing a subsidy to small businesses to help cope with the rise. See: http://english.yonhapnews.co.kr/news/2018/09/12/0200000000AEN20180912004251 320.html 
134 M. Lawson and M. Martin. (2018). Commitment to Reducing Inequality index 2018. op cit.

135 A.R. Thomas. (2018). Sierra Leone launches free school education. https://www.thesierraleonetelegraph.com/sierra-leone-launches-free-schooleducation/ and The Patriotic Vanguard. (2018). Sierra Leone: Parliament concludes debate on the 2019 budget. http://www.thepatrioticvanguard.com/sierra-leoneparliament-concludes-debate-on-the-2019-budget

136 J.D. Ostry et al. (forthcoming). Confronting Inequality. op. cit.

137 For details of poll and methodology see: D. Hardoon, F. Mager, A. Maitland and G. Zucman. (2018). Reward Work, Not Wealth: Methodology Note. Oxfam. https://www.oxfam.org/en/research/reward-work-not-wealth

138 In the 10 years since the financial crisis, the number of billionaires has risen from 1,125 in 2008 to 2,208 in 2018 . For more detail, please see methodology note: http://dx.doi.org/10.21201/2019.3651

139 The total fortune of those who have remained in the Forbes list consistently between 2017 and 2018 (about 1,900) has increased by about $\$ 900 \mathrm{bn}$ in one year, which is equivalent to an increase of $\$ 2.5 \mathrm{bn}$ per day. For more detail, please see methodology note: http://dx.doi.org/10.21201/2019.3651

140 The world has more billionaires than ever before. The Forbes list of billionaires (2018) expanded by 165 between 2017 and 2018. 316 new billionaires entered the list - more than double the number who left the list, which was 151. For more detail, please see methodology note: http://dx.doi.org/10.21201/2019.3651

141 Oxfam calculations based on Forbes. (2018). The World's Billionaires, op. cit, and Credit Suisse. (2018). World Wealth Report Databook. op. cit. For more detail, see methodology note: http://dx.doi.org/10.21201/2019.3651

142 Jeff Bezos' fortune in March 2018 was \$112bn. For Ethiopian Heath Budget calculations see: P. Espinoza Revollo et al. (2019). Public Good or Private Wealth? Methodology Note, op. cit.

143 Figure calculated based on Apple's reported annual revenue in 2017 (\$229.3bn). Available at: https://www.apple.com/newsroom/pdfs/fy17q4/Q4FY17ConsolidatedFinancialStatements.pdf

144 South China Morning Post. (2013, April 26). Sao Paulo's millionaires use helicopters to avoid traffic jams. https://www.scmp.com/news/world/article/1223071/sao-paulosmillionaires-use-helicopters-avoid-traffic-jams; The Guardian. (2016, November 25). How the super-rich beat Jakarta traffic. https://www.theguardian.com/cities/2016/nov/25/sky-commuters-how-super-rich-beatjakarta-traffic-hell-helicopter-helimousine-lippo-group

145 Mmills. (2014, April 06). 10 Universities Where Super Rich Kids Go. The Richest. https://www.therichest.com/rich-list/world/10-universities-where-super-rich-kids-go/

146 The Economist. (2018). Selling citizenship is big business - and controversial. https://www.economist.com/international/2018/09/29/selling-citizenship-is-bigbusiness-and-controversial

147 The other ways governments can tackle extreme concentration of wealth is to act to change the market inequalities that have produced such extremes in the first place. This is the topic of two previous Oxfam papers: D. Pimentel et al. (2018). Reward Work, Not Wealth (https://www.oxfam.org/en/research/reward-work-not-wealth) and D. Hardoon. (2017). An Economy for the 99\%. Oxfam. https://www.oxfam.org/en/research/economy-99

148 For example, see the evolution of top rates of tax in the US, France, Germany and the UK: https://ourworldindata.org/grapher/top-income-tax-rates-piketty. The UK top rate of tax in 2017 was 45\%, the same as it was in 1917.

149 A. Shorrocks et al. (2018). World Wealth Report 2018. op. cit.

$150 \mathrm{lbid}$. 
$151 \$ 7.6$ trillion estimate from G. Zucman. (2015). The Hidden Wealth of Nations. op. cit. $\$ 200$ billion estimate by G. Zucman for Oxfam D. Hardoon et al. (2018). Reward Work, Not Wealth: Methodology note. op. cit.

152 J. Meers. (2018, October 19). Cumex Files: European Taxpayers Cheater out of $€ 55$ Billion. Organized Crime and Corruption Reporting Project.

https://www.occrp.org/en/27-ccwatch/cc-watch-briefs/8772-cumex-files-europeantaxpayers-cheated-out-of-55-billion

153 D. Barstow, S. Craig and R. Buettner. (2018, October 2). Trump Engaged in Suspect Tax Schemes as He Reaped Riches From His Father. The New York Times. https://www.nytimes.com/interactive/2018/10/02/us/politics/donald-trump-taxschemes-fred-trump.html

154 R. Neate. (2018, August 9). Britain's richest person to leave UK for tax-free Monaco. The Guardian. https://www.theguardian.com/business/2018/aug/09/britains-richestman-to-leave-uk-for-tax-free-monaco

J. Henley. (2018, June 2). Citizenship for sale: how tycoons can go shopping for a new passport. The Guardian. https://www.theguardian.com/world/2018/jun/02/citizenshipby-investment-passport-super-rich-nationality

155 CEPAL. (2017). Panorama Fiscal de America Latina y El Caribe, p.47. https://repositorio.cepal.org/bitstream/handle/11362/41044/10/S1700069 es.pdf

156 See, for example, A. Laffer. (2004). The Laffer Curve: Past, Present and Future. Heritage Foundation.

157 IMF. (2017). Fiscal Monitor: Tackling Inequality. op. cit.

The Economist. (2018, August 9). Overhaul tax for the 21st century. https://www.economist.com/leaders/2018/08/09/overhaul-tax-for-the-21st-century

158 J. Ostry et al. (2014). Redistribution, Inequality and Growth. op. cit.

159 For a discussion of the impact that taxes and transfers can have on inequality, please see Joumard, Isabelle, Mauro Pisu and Debbie Bloch. (2012). Tackling income inequality: The role of taxes and transfers, OECD Journal: Economic Studies, published online first. http://dx.doi.org/10.1787/eco studies-2012-5k95xd6l65lt

160 While extreme poverty had been reducing by an average of one percentage point a year from 1990 to 2015 , it only reduced by 1.2 percentage point over the two years 2013-15 and it has been further slowing down since then. See World Bank. (2018a). Poverty and Shared Prosperity 2018. op. cit.

161 While extreme poverty had been reducing by an average of one percentage point a year from 1990 to 2015, it only reduced by one percentage point over the two years 2013-15. See: World Bank. (2018a). Poverty and Shared Prosperity 2018. op. cit.

162 World Bank. (2018a). Poverty and Shared Prosperity 2018. op. cit. finds that half of the world's population live on less than $\$ 5.50$ a day. 100 million people are pushed into extreme poverty by medical costs each year. World Health Organization and World Bank. (2017). Tracking Universal Health Coverage: 2017 Global Monitoring Report. op. cit.

163 World Bank. (2018a). Poverty and Shared Prosperity 2018. op. cit.

164 World Bank. (2016). A Cover Note to the Report of the Commission on Global Poverty.

http://pubdocs.worldbank.org/en/733161476724983858/MonitoringGlobalPovertyCove rNote.pdf

165 World Bank. (2018a). Poverty and Shared Prosperity 2018. op. cit.

166 World Bank. (2018a). Poverty and Shared Prosperity, op cit.

167 P. Espinoza Revollo et al. (2019). Public Good or Private Wealth? Methodology Note, op cit.

168 R. Kochhar. (2017). Middle Class Fortunes in Western Europe. http://www.pewglobal.org/2017/04/24/middle-class-fortunes-in-western-europe/ Pew Research Centre. 
169 F. Alvaredo, L. Chancel, T. Piketty, E. Saez and G. Zucman. (2017). The World Inequality Report 2018. World Inequality Lab. https://wir2018.wid.world

170 The World Bank's projections show that at current rates of economic growth, extreme poverty will not be eradicated by 2030 unless inequality is reduced by making the income of the bottom $40 \%$ of the population grow faster than that of the rest. Without inequality reduction, even with double rates of economic growth, about $3.7 \%$ of the global population will be living in extreme poverty. World Bank. (2018a). Poverty and Shared Prosperity 2018. op. cit. p.24.

171 Globally, men are estimated to own $60 \%$ of wealth. See: A. Shorrocks et al. (2018) World Wealth Report 2018. op. cit.

172 UN Women. (2018). Turning Promises Into Action. op. cit.

173 A. Shorrocks et al. (2018). World Wealth Report 2018. op. cit.

174 A. Shorrocks, J. Davies and R. Lluberas. (2018). Global Wealth Report. https://www.credit-suisse.com/corporate/en/research/research-institute/global-wealthreport.html

175 M. Chang. (2015). Women and Wealth: Insights for grantmakers, Asset Funders Network. https://www.mariko-chang.com/AFN Women and Wealth Brief 2015.pdf

176 A. Guereña and S. Burgos. (2016). Unearthed: Land, Power And Inequality In Latin America, https://www.oxfam.org/sites/www.oxfam.org/files/file attachments/bp-landpower-inequality-latin-america-301116-en.pdf and M.R. Carter. (2000). Land Ownership Inequality and the Income Distribution Consequences of Economic Growth. WIDER Working Papers (1986-2000) 2000/201. Helsinki: UNU-WIDER. https://www.wider.unu.edu/publication/land-ownership-inequality-and-incomedistribution-consequences-economic-growth

177 World Bank. (2012). World Development Report 2012: Gender Equality and Development. https://openknowledge.worldbank.org/handle/10986/4391

178 Calculated using data on the incidence of female and male agricultural landowners as a proportion of the total female and male population. Source: Living Standards Measurements Study - Bangladesh Integrated Household Survey found in FAO Gender and Land Rights Database: http://www.fao.org/gender-landrightsdatabase/en/

179 M. Chang. (2015). Women and Wealth: Insights for grantmakers. Asset Funders Network. https://www.mariko-chang.com/AFN Women and Wealth Brief 2015.pdf

180 C.D. Deere and C.R. Doss. (2006). The Gender Asset Gap: What Do We Know and Why Does It Matter? Feminist Economics, 12(1-2): 1-50. https://doi.org/10.1080/13545700500508056

181 D. Pimentel et al. (2018). Reward Work, Not Wealth, op. cit.

182 World Bank. (2012). World Development Report 2012, op cit.

183 IMF. (2018). Pursuing Women's Economic Empowerment. https://www.imf.org/en/Publications/PolicyPapers/Issues/2018/05/31/pp053118pursuing-womens-economic-empowerment

184 World Bank. (2018a). Poverty and Shared Prosperity 2018. op. cit.

185 See, for example, M. Wolf. (2017, June 27). The economic origins of the populist surge. Financial Times. https://www.ft.com/content/5557f806-5a75-11e7-9bc8$\underline{8055 f 264 a a 8 b}$ or Council on Foreign Relations. (2017, February 23). Inequality and the rise of Authoritarianism. Transcript of panel featuring J.A. Goldstone, K.R. McNamara and S. Hamid. https://www.cfr.org/event/inequality-and-riseauthoritarianism

186 E.D. Gould and A. Hijzen. (2016). Growing Apart, Losing Trust? The Impact of Inequality on Social Capital. IMF. Working Paper WP/16/176. https://www.imf.org/external/pubs/ft/wp/2016/wp16176.pdf

187 P. Fajnzylber, D. Lederman and N. Loayza. (2002). Inequality and Violent Crime. Journal of Law and Economics, 45(1):1-40. https://doi.org/10.1086/338347; R. Wilkinson and K. Pickett (2009). The Spirit Level. op. cit. 
188 R. Wilkinson and K. Pickett. (2018). The Inner Level. op. cit.

189 T. Gore. (2015). Extreme Carbon Inequality. Oxfam Media Briefing. https://www.oxfam.org/sites/www.oxfam.org/files/file attachments/mb-extremecarbon-inequality-021215-en.pdf

190 D. Woodward. (2015). Incrementum ad Absurdum: Global Growth, Inequality and Poverty Eradication in a Carbon-Constrained World. World Social and Economic Review, 4:43-62. http://wer.worldeconomicsassociation.org/files/WEA-WER-4Woodward.pdf

191 A. Narayan, R. Van der Weider, A. Cojocaru, C. Lakner, S. Redaelli, D.G. Mahler, R.G.N. Ramasubbaiah and S. Thewissen. (2018). Fair Progress? Economic Mobility across Generations around the World. World Bank. https://www.worldbank.org/en/topic/poverty/publication/fair-progress-economicmobility-across-generations-around-the-world

O. Galor and J. Zeira. (1993). Income Distribution and Macroeconomics. The Review of Economic Studies, 60(1): 35-52. https://academic.oup.com/restud/articleabstract/60/1/35/1576085? redirectedFrom=fulltext

192 A. Narayan et al. (2018). Fair Progress? Economic Mobility across Generations around the World. op. cit.

193 lbid.

194 H.X. Thanh. (2018). Social Mobility and Equality of Opportunity in Vietnam: Trends and impact factors. Oxfam in Vietnam. https://vietnam.oxfam.org/policy paper/socialmobility-and-equality-opportunity-vietnam-trends-and-impact-factors

195 C. Daude. (2013). Education and Social Mobility in Latin America. LASA Forum, XLIV (2):7-9. https://forum.lasaweb.org/files/vol44-issue2/Debates3.pdf

196 El Colegio de México. (2016). Encuesta de Movilidad Social. Retrieved September 2018, from Resultados. https://movilidadsocial.colmex.mx/index.php/resultados

197 Figures taken from Kenya Demographic and Health Survey 2014, tables 3.2.1 and 3.2.2. Only $0.4 \%$ of young women from the lowest wealth quintile continue their education beyond secondary level, compared to $35.7 \%$ of young men from the richest wealth quintile. Kenya National Bureau of Statistics. (2015). Kenya Demographic and Health Survey 2014. https://dhsprogram.com/pubs/pdf/fr308/fr308.pdf

198 Figures taken from Kenya Demographic and Health Survey 2014, op. cit. A child from the wealthiest quintile has on average 11.78 years of education, compared to 6.15 for a child from the poorest quintile.

199 Global Campaign for Education Privatisation Paper. (2016). Private Profit, Public Loss: why the push for low-fee private schools is throwing quality education off track. http://www.right-to-education.org/resource/private-profit-public-loss-why-push-low-feeprivate-schools-throwing-quality-education

200 Ministry of Health - MOH/Nepal, New ERA/Nepal, and ICF. (2017). Nepal Demographic and Health Survey 2016. Kathmandu, Nepal: MOH/Nepal, New ERA/Nepal, and ICF. Available at: https://dhsprogram.com/publications/publicationfr336-dhs-final-reports.cfm. Tables 8.3, 3.3.1. and 3.3.2.

201 Infant mortality rate for the US black population is 11.4 for 1,000 live births and that of the US white population is 4.9. Source: '2016 Period Linked Birth/Infant Death Data Set'. National Centre for Health and Statistics, Centers for Disease Control and Prevention (p.80). Available at: ftp://ftp.cdc.gov/pub/Health Statistics/NCHS/Dataset Documentation/DVS/periodlinke d/LinkPE16Guide.pdf

202 Ibid. Libya's infant mortality rate in 2016 was 10.6. Source: The World Bank. (2018b). Mortality rate, infant (per 1,000 live births) | Data. Available at: https://data.worldbank.org/indicator/SP.DYN.IMRT.IN

203 J.L. Ward and R.M. Viner. (2017). The impact of income inequality and national wealth on child and adolescent mortality in low and middle-income countries. BMC Public Health 17:429. https://doi.org/10.1186/s12889-017-4310-z 
204 A. Marriott. (2009). Blind Optimism: Challenging the myths about private healthcare in poor countries. op. cit.

205 Indian Institute of Dalit Studies. (2012). Social Exclusion and Rural Poverty: Role of Discrimination and General Factors in Access to Government Schemes for Employment, Food, Health Services, Agricultural Land and Forest Resources in the Poorest Areas in India. New Delhi: Indian Institute of Dalit Studies. http://www.dalitstudies.org.in/completed-programmes-projects.php?\&p=2

206 Office for National Statistics. (2014). Life Expectancy at Birth and at Age 65 by Local Areas in the United Kingdom: 2006-08 to 2010-12.

https://www.ons.gov.uk/peoplepopulationandcommunity/birthsdeathsandmarriages/life expectancies/bulletins/lifeexpectancyatbirthandatage65bylocalareasintheunitedkingdo $\underline{\mathrm{m} / 2014-04-16 \text { \#animated-maps-and-reference-tables }}$

207 Rede Nossa São Paulo. (2017). op. cit.

208 Oxfam international. (2017). An Economy for the 99\%. op. cit.

209 J. Ostry et al. (2018). Economic Gains From Gender Inclusion: New Mechanisms, New Evidence. IMF. Staff Discussion Note SDN 18/06. https://doi.org/10.5089/9781484337127.006

210 lbid.

211 See, for example: I. Illkkaracan, K. Kim and T. Kaya. (2015). The Impact of Public Investment in Social Care Services on Employment, Gender Equality, and Poverty: The Turkish Case. Istanbul Technical University Women's Studies Center in Science, Engineering and Technology and The Levy Economics Institute. http://www.levyinstitute.org/pubs/rpr 8 15.pdf; and Q. Wodon, C. Montenegro, $\mathrm{H}$. Nguyen and A. Onagoruwa. (2018). Missed Opportunities: The high cost of not educating girls. op. cit.

212 M. Cerrutti. (2000). Economic Reform, Structural Adjustment and Female Labor Force Participation in Buenos Aires, Argentina. World Development, 28(5): 879-91. https://doi.org/10.1016/S0305-750X(99)00163-1

213 European Women's Lobby. (2012). The price of austerity - The impact on women's rights and gender equality in Europe. Retrieved from https://www.womenlobby.org/lMG/pdf/the price of austerity - web edition.pdf

214 World Health Organization. (2018). Women in the Health Workforce http://www.who.int/hrh/events/2018/women-in-health-workforce/en/. Also see World Bank. (2017). Primary education, teachers (\% female). https://data.worldbank.org/indicator/SE.PRM.TCHR.FE.ZS

$215 \mathrm{lbid}$. Women make up $70 \%$ of the world's health workers, and $65 \%$ of the world's primary school teachers.

216 See, for example, I. Illkkaracan et. al. (2015). The Impact of Public Investment in Social Care Services on Employment, Gender Equality, and Poverty. op. cit; Q. Wodon et al. (2018). Missed Opportunities: The high cost of not educating girls. op. cit.

217 K.A. Lahey. (2018). Gender, Taxation and Equality in Developing Countries. UN Women. http://gender-financing.unwomen.org/en/resources/g/e/n/gender-andtaxation-discussion-paper

218 C. Ngozi Adichie. (2014). We Should All Be Feminists. Penguin Random House.

219 McKinsey Global Institute. (2015). The Power of Parity. op. cit.

220 Figure calculated based on Apple's reported annual revenue in 2017 (\$229.3 billion) available at: Apple Inc. Condensed Consolidated Statements Of Operations (Unaudited) https://www.apple.com/newsroom/pdfs/fy17g4/Q4FY17ConsolidatedFinancialStatements.pdf

221 Figure calculated based on Apple's reported annual revenue in 2017 (\$229.3bn). Available at: https://www.apple.com/newsroom/pdfs/fy17q4/Q4FY17ConsolidatedFinancialStatements.pdf 
222 These are figures for total care work, including where unpaid care is being done alongside other activities. L. Karimli, E. Samman, L. Rost and T. Kidder. (2016). Factors and Norms Influencing Unpaid Care Work: Household survey evidence from five rural communities in Colombia, Ethiopia, the Philippines, Uganda and Zimbabwe. Oxfam. https://oxfamilibrary.openrepository.com/bitstream/10546/620145/1/erhousehold-care-survey-wecare-151116-en.pdf.

$223 \mathrm{lbid}$. An average figure for hours spent by women and men on unpaid care as a primary activity, based on data from two separate studies covering six developing countries; and E. Pacheco and N. Florez. (2014). 'Entre lo rural y lo urbano. Tiempo y desigualdades de genero', in B. Garcia and E. Pacheco (eds.) Uso del tiempo y trabajo no remunerdado en Mexico. pp.223-63. https://www.jstor.org/stable/j.ctt1r69w16

224 In Tunisia in $2011 / 12,81 \%$ of 3 - to 4 -year-olds from the richest $20 \%$ of households attended an early childhood education programme, whereas only $13 \%$ of 3 - to 4 -yearolds from the poorest $20 \%$ of households attended an early childhood education programme. Sources: UNESCO. (2016). Education for people and planet: Creating sustainable futures for all. Global Education Monitoring Report 2016. https://en.unesco.org/gem-report/report/2016/education-people-and-planet-creatingsustainable-futures-all and Ministère du Développement et de la Coopération Internationale, $\mathrm{MDCl}$ - Institut National de la Statistique et Fonds des Nations Unies pour l'Enfance. (2013). Suivi de la situation des enfants et des femmes en TunisieEnquête par grappes à indicateurs multiples 2011-2012, Rapport Final, Juin 2013. http://mics.unicef.org/surveys

225 Inter-American Development Bank (IDB). (2016, July 21). IDB supports Uruguay's National Integrated Care System. https://www.iadb.org/en/news/news-releases/201607-21/uruguays-national-integrated-care-system\%2C11522.html

226 V. Esquival and A. Kaufmann. (2017). Innovations in Care: New Concepts, New Actors, New Policies. Friedrick-Ebert-Stiftung. http://library.fes.de/pdffiles/iez/13282.pdf

227 A. Langer et al. (2015). Women and Health: the key for sustainable development, op. cit; B. Heilman et al. (2017). State of the World's Fathers: Time for Action. op. cit.

228 A. Parvez Butt et al. (2018). Exploring the Need for Gender-Equitable Fiscal Policies for a Human Economy: Evidence from Uganda and Zimbabwe. Oxfam Research Report. https://doi.org/10.21201/2017.1725

229 R. Paes de Barros et al. (2011). The Impact of Free Childcare on Women's Labor Force Participation: Evidence from Low-Income Neighborhoods of Rio de Janeiro. Conference Paper, World Bank Economists' Forum 2010. https://siteresources.worldbank.org/DEC/Resources/84797-1104597464088/5984131302096012728/Pedro-Olinto access to free childcare.pdf

230 J. De Henau, S. Himmelweit and D. Perrons. (2017). Investing in the care economy: Simulating employment effects by gender in countries in emerging economies. International Trade Union Confederation. https://www.ituccsi.org/lMG/pdf/care economy 2 en web.pdf

231 K. Kim, I. İlkkaracan and T. Kaya. (2017). Investing in Social Care Infrastructure and Employment Generation: A Distributional Analysis of the Care Economy in Turkey. Levy Economics Institute Working Paper No. 882. https://doi.org/10.2139/ssrn.2924794

232 B. Jacobs et al. (2011). Addressing access barriers to health services: an analytical framework for selecting appropriate interventions in low-income Asian countries. Health Policy and Planning, 2011:1-13. http://www.who.int/alliancehpsr/resources/alliancehpsr jacobs ir barriershealth2011.pdf

World Health Organization Western Pacific Region. (2007). Reaching the Poor: Challenges for Child Health in the Western Pacific Region, chapter 7. http://www.wpro.who.int/publications/docs/ReachingthePoor ChildHealthandPoverty Part2.pdf

O. O'Donnell. (2007). Access to health care in developing countries: breaking down demand side barriers. Cadernos de Saúde Pública, 23(12):2820-34. http://www.scielo.br/scielo.php?script=sci arttext\&pid=S0102-311X2007001200003 
233 C. Chiang, S.A. Labeeb, M. Higuchi, A.G. Mohamed, A. Aoyama. (2013). Barriers to the use of basic health services among women in rural southern Egypt (Upper Egypt). Nagoya Journal of Medical Science, 75(3-4):225-31. https://www.ncbi.nlm.nih.gov/pmc/articles/PMC4345669/

234 See, for example, A. Green. (1990). Education and State Formation: the Rise of Education Systems in England, France and the USA. London: Macmillan.

O. Grell, A. Cunningham and R. Jütte (eds). (2002). Health care and poor relief in 18th and 19th century Northern Europe. Abingdon: Routledge.

235 G. Verbist, M.F. Förster and M. Vaalavuo (2012) The Impact of Publicly Provided Services on the Distribution of Resources: Review of New Results and Methods. OECD Social, Employment and Migration Working Papers, No. 130, OECD Publishing, p.35.

https://www.researchgate.net/publication/241764369 The Impact of Publicly Provid ed Services on the Distribution of Resources Review of New Results and Meth ods.

236 I. Marx, B. Nolan and J. Olivera. (2015). The Welfare State and Antipoverty Policy in Rich Countries. In A.B. Atkinson and F. Bourguignon. (eds). Handbook of Income Distribution, Vol. 2B, pp.2063-2139. Amsterdam: Elsevier. https://doi.org/10.1016/B978-0-444-59429-7.00024-8

237 For the period 1970-2009. J. Martinez-Vazquez, V. Vulovic and B. Moreno-Dodson. (2012). The Impact of Tax and Expenditure Policies on Income Distribution: Evidence from a Large Panel of Countries. Review of Public Economics 200:95-130.

238 N. Lustig. (2015). The Redistributive Impact of Government Spending on Education and Health. op. cit.

239 GPE Secretariat. (2016). 5 ways education can help end extreme poverty. op. cit.

240 World Health Organization and World Bank. (2017). Tracking Universal Health Coverage: 2017 Global Monitoring Report. op. cit.

$241 \mathrm{lbid}$.

242 A. Harris. (2016). 10 reasons why clean water can help end poverty. Plan International. https://plan-uk.org/blogs/10-reasons-why-clean-water-can-help-endpoverty

243 United Nations Development Programme (2006), Human Development Report 2006, Beyond Scarcity: power poverty and the global water crisis. New York: Palgrave Macmillan, p.45. Available at: http://hdr.undp.org/en/content/human-developmentreport-2006.

244 lbid.

245 IMF. (2017). Fiscal Monitor: Tackling Inequality. op. cit.

246 Own calculations based on the World Bank's World Development Indicators (WDI) database. GDP per capita figures for Thailand and Ethiopia were rebased from 2011 PPP USD to 1990 PPP USD. This was done by multiplying each value of the real GDP in 2011 PPP $\$$ by the ratio of the 2011 GDP per capita in 2011 PPP USD to the 2011 GDP per capita in current USD. Note, this is only an approximation to the ideal real GDP per capita in 1990 PPP USD. US and Canadian GDP figures taken from J. Bolt, M. Timmer and J.L. van Zanden. (2014). GDP per capita since 1820. https://www.oecd-ilibrary.org/economics/how-was-life/gdp-per-capita-since$18209789264214262-7-e n$. In J. van Zanden et al. (eds.) How Was Life? Global Well-being since 1820. Paris: OECD. https://www.oecd-ilibrary.org/economics/howwas-life 9789264214262-en. P. Espinoza Revollo et al. (2019). Public Good or Private Wealth? Methodology Note, op. cit.

247 V. Tangcharoensathien et. al. (2018). Health systems development in Thailand. op cit.

248 Netherlands Embassy in Bangkok. (2018). Life Sciences and Health in Thailand. Netherlands Ministry of Foreign Affairs. https://www.netherlandsworldwide.nl/binaries/ennederlandwereldwijd/documents/publications/2018/04/18/factsheet-life-sciences-health-in-thailand/Thailand+-+Factsheet+Life+Sciences+\%26+Health.pdf 
249 V. Tangcharoensathien et al. (2018). Health systems development in Thailand. op. cit.

250 People in the poorest quintile use both inpatient and outpatient healthcare services more than the richest. Benefit incidence analysis also confirms that government subsidies went more frequently to the poorest group than the richest. $S$.

Limwattananon, $\mathrm{V}$. Tangcharoensathien, $\mathrm{K}$. Tisayaticom, $\mathrm{T}$.

Boonyapaisarncharoen and P. Prakongsai. (2012). Why has the Universal Coverage Scheme in Thailand achieved a pro-poor public subsidy for health care? BMC Public Health, 12(Suppl 1): S6. https://www.ncbi.nlm.nih.gov/pmc/articles/PMC3382621/

251 Own calculations based on the World Bank's WDI database. GDP per capita figures for Thailand and Ethiopia were rebased from 2011 PPP USD to 1990 PPP USD. This was done by multiplying each value of the real GDP in 2011 PPP USD by the ratio of the 2011 GDP per capita in 2011 PPP USD to the 2011 GDP per capita in current USD. Note, this is only an approximation to the ideal real GDP per capita in 1990 PPP USD. US and Canadian GDP figures taken from J. Bolt et al. (2014). GDP per capita since 1820. P. Espinoza Revollo et al. (2019). Public Good or Private Wealth? Methodology Note, op. cit.

252 Based on a pupil-teacher ratio of 55:1 and a primary school population of 25 million. Using UNESCO Institute for Statistics data from World Bank Data. https://data.worldbank.org/indicator/SE.PRM.ENRL.TC.ZS?locations=ET

253 Z. Paulos and A. Zeyede. (2017). National Education Sector Budget Brief: 20062016. UNICEF Ethiopia. https://www.unicef.org/esaro/UNICEF Ethiopia -- 2017 -Education Budget Brief.pdf

254 Ibid.

255 WaterAid. (2017). Wild Water: The State of the World's Water. https://reliefweb.int/report/world/wild-water-state-world-s-water-2017

256 A. Harris. (2016). 10 reasons why clean water can help end poverty. op. cit.

257 The World Bank. (2018). World Development Report 2018. op. cit.

258 Globally, the number of deaths of children under 5 years of age fell from 12.7 million in 1990 to 6.3 million in 2013. UNICEF. (2018). Child Mortality - UNICEF Data. https://data.unicef.org/topic/child-survival/under-five-mortality/

259 UN-AIDS. (2014). The Gap Report. http://www.unaids.org/sites/default/files/media asset/UNAIDS Gap report en.pdf

260 World Health Organization and World Bank. (2017). Tracking Universal Health Coverage: 2017 Global Monitoring Report. op. cit.

261 UNESCO. (2017). Global Education Monitoring Report 2017/8. op. cit.

262 lbid.

263 World Health Organization and UNICEF. (2017). Progress on Drinking Water, Sanitation and Hygiene. http://apps.who.int/iris/bitstream/handle/10665/258617/9789241512893eng.pdf?sequence $=1$

264 World Bank. (2018). World Development Report 2018. op. cit.

265 F. Chao et. al. (2018). National and regional under-5 mortality rate by economic status for low-income and middle-income countries. op. cit.

266 Figures from Health Equity Assessment Toolkit (HEAT). https://whoequity.shinyapps.io/HEAT/

267 M. Kruk et al. (2018). Mortality due to low-quality health systems in the universal health coverage era. op. cit.

268 Dr M. Mackintosh et al. (2016). What Is The Private Sector? Understanding Private Provision In The Health Systems Of Low-Income And Middle-Income Countries. The Lancet, 388. https://doi.org/10.1016/S0140-6736(16)00342-1 
269 ICICI Securities Ltd. (2017). World class health infra at competitive prices to fuel Indian medical tourism boom.

http://content.icicidirect.com/mailimages/MedicalTourismFeb17.htm

270 lbid.

271 M. Kruk et al. (2018). Mortality due to low-quality health systems in the universal health coverage era. op. cit.

272 Dr M. Mackintosh et al. (2016). What Is The Private Sector? op. cit.

273 S. Kumar Hooda (June 28, 2018). NHPS is simply not sustainable. Financial Express.

https://www.researchgate.net/publication/327437290 NHPS is simply not sustainab le and https://www.indiatoday.in/magazine/up-front/story/20181008-modicare-morebusiness-less-care-1350008-2018-09-28

274 National Commission for Protection of Child Rights, Government of India. (2013). Utilization of Free Medical Services by Children Belonging to the Economically Weaker Sections (EWS) in Private Hospitals in New Delhi, 2011-12; A Rapid Appraisal. http://ncpcr.gov.in/showfile.php?lid=115; J. Singh. (2015). Delhi hospitals freed of poor. https://www.downtoearth.org.in/coverage/delhi-hospitals-freed-of-poor44376; A Dutt. (2018). SC reads riot act to Delhi's private hospitals, orders free treatment of poor. Hindustan Times. https://www.hindustantimes.com/india-news/screads-riot-act-to-delhi-s-private-hospitals-orders-free-treatment-of-poor/storyaUXWZBW7wJhARZ3Ss0FOpJ.html

275 Oxfam India. (2015). Financing Healthcare for all in India: Towards a Common Goal. https://oxfamilibrary.openrepository.com/bitstream/handle/10546/556476/wpfinancing-healthcare-for-all-india-290515-en.pdf?sequence $=1$

276 N. Devadasan, T. Seshdri, M. Trivedi and B. Criel. (2013). Promoting universal financial protection: evidence from the Rashtriya Swasthya Bima Yojana (RSBY) in Gujarat, India. Health Research Policy and Systems, Volume 11, No.1; S. Nandi et. al. (2012). The Implementation of RSBY in Chhattisgarh, India: A study of the Durg district, Volume 2, No.1. https://hcs.pitt.edu/ojs/index.php/hcs/article/view/61/99. S. Nandi. (2018). Modicare: More business, less care.

https://www.indiatoday.in/magazine/up-front/story/20181008-modicare-morebusiness-less-care-1350008-2018-09-28. Dr M. Nundy et al. (2013) The Rashtriya Swasthya Bima Yojana (RSBY) Experience in Chhattisgarh Sama - Resource Group for Women and Health: What does it mean for Health for All? http://phrsindia.org/wpcontent/uploads/2015/08/RSBY Health-for-All CG-experience.pdf

277 R. Srivastava. (2018). Private doctors perform most hysterectomies in India: Survey. Reuters (2018, January 11). https://www.reuters.com/article/us-india-womenhealth/private-doctors-perform-most-hysterectomies-in-india-surveyidUSKBN1F02GJ; Oxfam. (2013). Unregulated and Unaccountable: How the private health care sector in India is putting women's lives at risk. https://oxfamilibrary.openrepository.com/bitstream/handle/10546/268392/mbunregulated-unaccountable-private-healthcare-india-060213-en.pdf?sequence $=1 ; \mathrm{N}$. Kohli (2018, September 18) Experts raise concerns about rising hysterectomies in India. This Week. https://www.theweek.in/leisure/lifestyle/2018/09/18/Experts-raiseconcern-about-rising-hysterectomies-in-India.html

278 The World Bank. (2018). World Development Report 2018. op. cit.

279 In times of drought, the price for 20 litres of water rises to 20 Kenyan shillings (KES) (\$0.2) per litre for the poorest people. Public water is $0.5 \mathrm{KES}$ per litre. M. Schreurs. (2018). Correspondence with author. (Marcels Schreurs is the Managing Director of Maji Mielele Ltd.).

280 M. Lawson and M. Martin. (2018). Commitment to Reducing Inequality index 2018. op. cit.

281 See, for example, World Bank. (2004). World Development Report 2004: Making Services Work for Poor People. https://openknowledge.worldbank.org/handle/10986/5986

282 IMF. (2017). Fiscal Monitor: Tackling Inequality. op. cit. and C. Mariotti et al. (2017). Great expectations: is the IMF turning words into action on inequality? 
https://www.oxfam.org/en/research/great-expectations-imf-turning-words-actioninequality. Oxfam International

283 I. Ortiz and M. Cummins. (2013). Austerity Measures in Developing Countries: Public Expenditure Trends and the Risks to Children and Women. Feminist Economics, 19(3):55-81.

https://www.tandfonline.com/doi/abs/10.1080/13545701.2013.791027?src=recsys\&jo urnalCode=rfec20

T. Cavero and K. Poinasamy. (2013). A Cautionary Tale: The true cost of austerity and inequality in Europe. Oxfam. https://policy-practice.oxfam.org.uk/publications/acautionary-tale-the-true-cost-of-austerity-and-inequality-in-europe-301384

284 World Bank. (2004). World Development Report 2004. op. cit.; Oxfam. (2018). Harmful side effects: how drug companies undermine global health. https://policypractice.oxfam.org.uk/publications/harmful-side-effects-how-drug-companiesundermine-global-health-620547.

285 Oxfam. (2018). Harmful side effects. op. cit.

286 D. Gotham et. al. (2017). Estimated generic prices for novel treatments for drugresistant tuberculosis. Journal of Antimicrobial Chemotherapy, 72(4): 1243-52. https://doi.org/10.1093/jac/dkw522

287 E.Seery (2014). Working for the Many: Public services fight inequality. Oxfam. http://oxf.am/RZn

288 In her work with the Commitment to Equity (CEQ) Institute, Nora Lustig identifies four types of income inequality. The first is market inequality, or the inequality that results from allocation of income to households and enterprises before government intervention through taxes and transfers. The second is disposable income, the amount of income after direct taxes and transfers. The third is consumable income, the amount remaining after indirect taxes and transfers, and the final income is the amount when the cash value of education and health services are taken into account. See, for example, N. Lustig. (2017). Fiscal policy, Inequality and the Poor in the Developing World. http://www.commitmentoequity.org/wpcontent/uploads/2017/08/CEQ WP23 Lustig July2017v2.pdf. See also E. Seery (2014). op. cit.

289 P. Espinoza Revollo et al. (2019). Public Good or Private Wealth? Methodology Note, op. cit.

290 In almost half of the countries (36), education spending per pupil is worth double the per capita income of the poorest people; and in 9 countries, it is worth more than 4 times.

291 Oxfam calculations. P. Espinoza Revollo et al. (2019). Public Good or Private Wealth? Methodology Note, op. cit.

292 T. Burgess. (2016). Water: At What Cost? The State of the World's Water 2016. WaterAid. https://www.jica.go.jp/activities/issues/water/ku57pq00002cybbnatt/water at what cost wateraid 2016.pdf

293 Ibid.

294 G. Verbist et al. (2012). The Impact of Publicly Provided Services on the Distribution of Resources. op cit.

295 N. Lustig, L.F. Lopez-Calva and E. Ortiz-Juarez. (2012). Declining Inequality in Latin America in the 2000s: The Cases of Argentina, Brazil, and Mexico. Center for Global Development. Working Paper 307.

G.A. Cornia. (2014). Falling Inequality in Latin America: Policy Changes and Lessons. Oxford: Oxford University Press.

296 The role that well-designed public services and social protection can play in tackling unpaid care has already been discussed in section 2 .

297 Q. Wodon et al. (2018). Missed Opportunities: The high cost of not educating girls. op. cit. 
298 J. Walker and C. Pearce. (forthcoming). Levelling Up: Education and Inequality. Oxfam Briefing Paper.

299 All data in this paragraph from: UNESCO. (2013). Education transforms lives. http://unesdoc.unesco.org/images/0022/002231/223115e.pdf

300 N. Williamson. (2013). State of World Population 2013, Motherhood in Childhood: Facing the challenge of adolescent pregnancy. United Nations Population Fund (UNFPA). https://www.unfpa.org/publications/state-world-population-2013

World Health Organization. (2011). Preventing early pregnancy and poor reproductive outcomes among adolescents in developing countries. WHO guidelines. https://www.who.int/maternal child adolescent/documents/preventing early pregnan cy/en/

301 UNESCO. (2014). Teaching and Learning: Achieving quality for all. Education For All Global Monitoring Report. https://en.unesco.org/gem-report/report/2014/teaching-andlearning-achieving-quality-all

302 UN Women. (2015). Progress of the World's Women 2015-2016: Transforming Economies, Realizing Rights. http://progress.unwomen.org/en/2015/pdf/UNW progressreport.pdf

303 International Labour Office (ILO). (2018a). Social protection for older persons: Policy trends and statistics 2017-19. ILO Social protection policy paper no. 17. https://www.ilo.org/wcmsp5/groups/public/---ed protect/--soc sec/documents/publication/wcms 645692.pdf

304 Ibid. p.87 and UN Women. (2015). Progress of the World's Women 2015-2016. op. cit., figures 3.4 and 3.5 .

305 UNFPA. (2017). State of World Population 2017, Worlds Apart: Reproductive health and rights in an age of inequality.

https://www.unfpa.org/sites/default/files/sowp/downloads/UNFPA PUB 2017 EN S WOP.pdf

306 A. Johnson, A. Goss, J. Beckerman and A. Castro. (2012). Hidden costs: The direct and indirect impact of user fees on access to malaria treatment and primary care in Mali. Social Science and Medicine 75(10): 1786-92.

https://doi.org/10.1016/j.socscimed.2012.07.015

307 A. Coote. (2017). Are universal public services the answer to Europe's widening inequalities? The New Economics Foundation.

https://neweconomics.org/2017/12/universal-public-services-answer-europeswidening-inequalities

308 B. McPake. (2009). Hospital Policy In Sub-Saharan Africa And Post-Colonial Development Impasse, Social History of Medicine, Volume 22. https://doi.org/10.1093/shm/hkp007

309 DFID. (2011). Cash Transfers - Evidence Paper. DFID Policy Division. http://www.who.int/alliance-hpsr/alliancehpsr dfidevidencepaper.pdf

310 I. Idris. (2017). Conflict-sensitive cash transfers: social cohesion. https://opendocs.ids.ac.uk/opendocs/bitstream/handle/123456789/13248/201\%20Con flictsensitive $\% 20$ cash $\% 20$ transfers $\% 20$ and $\% 20$ social $\% 20$ cohesion.pdf?sequence $=1 \&$ is llowed=y K4D

311 The Hindu. (2011). Public Education is Indispensable. https://www.thehindu.com/todays-paper/tp-national/Public-education-is-indispensablesays-Nobel-laureate-Amartya-Sen/article14898488.ece

312 lbid.

313 lbid.

314 United Nations Department on Economic and Social Affairs. (2018). Promoting Inclusion Through Social Protection. https://www.un.org/development/desa/dspd/wpcontent/uploads/sites/22/2018/07/1-1.pdf

315 World Bank. (2004). World Development Report 2004. op. cit. 
316 For example, trust in institutions tends to be positively associated with levels of satisfaction with the education system. Lack of trust in the education system can lead to a disengaged public that believes its voice will not be heard and searches for alternative provision. UNESCO. (2018). Accountability in Education: Meeting our Commitments Global Monitoring Report, page 10. http://unesdoc.unesco.org/images/0025/002593/259338e.pdf

317 A. Narayan et al. (2018). Fair Progress? Economic Mobility across Generations around the World. op. cit.

318 A. Sen. (1999). Development as Freedom. Oxford University Press.

319 P. Freire. (1970). The Pedagogy of the Oppressed. (M. Bergman Ramos, Trans.). London: Penguin.

320 See a review in D.E. Campbell. (2006). What is education's impact on civil and social engagement? http://www.oecd.org/education/innovation-education/37425694.pdf In OECD. Measuring the effects of education on health and civic engagement Proceedings of the Copenhagen Symposium. http://www.oecd.org/education/innovationeducation/measuringtheeffectsofeducationonhealthandcivicengagement.htm

321 Q. Wodon et al. (2018). Missed Opportunities: The high cost of not educating girls. op. cit.

322 B. Rothstein. (1998). Just Institutions Matter: The Moral and Political Logic of the Universal Welfare State. Cambridge: Cambridge University Press. https://doi.org/10.1017/CBO9780511598449

323 lbid.

324 lbid.

325 World Bank. (2019). World Development Report 2019: The Changing Nature of Work. http://www.worldbank.org/en/publication/wdr2019. This report argues for 'progressive universalism', saying that universal social protection is not viable.

326 lbid.

See also: World Bank. (2004). World Development Report 2004. op. cit.

327 S. Kidd. (2018, March 27). International donors and the exporting of 19th Century Poor Relief to developing countries. From Oxfam's Poverty to Power blog. https://oxfamblogs.org/fp2p/international-donors-and-the-exporting-of-19th-centurypoor-relief-to-developing-countries/

328 B. Emmett. (2007). In the Public Interest. op. cit.; D. Balabanova, M. McKee and A. Mills. (2011). Good health care at low cost 25 years on: What makes a successful health system? https://ghlc.lshtm.ac.uk/,

329 D. Balabanova et al. (2011). Good health care at low cost 25 years on. op. cit.

330 R. Sabates-Wheeler, A. Hurrell, and S. Devereux. (2014). Targeting social transfer programmes. Comparing design and implementation errors across alternative mechanisms. WIDER Working Paper.

https://www.wider.unu.edu/sites/default/files/wp2014-040.pdf; S. Kidd (2013)

Rethinking targeting in International Development. Development Pathways. http://www.developmentpathways.co.uk/wp-content/uploads/2013/10/11PathwaysPerspective-Rethinking-Targeting-Kidd.pdf

331 S. Kidd. (2018). Pro-poor or anti-poor? The World Bank and IMF's approach to social protection. Bretton Woods Project Briefing Paper. London.

332 Sources: Analysis conducted by Development Pathways of the following datasets: Listening to the Citizens of Uzbekistan Survey 2018 (L2CU); Philippines' Annual Poverty Indicators Survey (APIS) 2014; Bolivia's Encuesta de Hogares 2015; South Africa's General Household Survey (GHS) 2015; Ethiopia Socioeconomic Survey (ESS) 2013/2014; India Human Development Survey-II (IHDSS-II) 2011/2012; Indonesia's National Socio-Economic Survey (SUSENAS) 2015; Vietnam Household Living Standards Survey (VHLSS) 2012. Alatas, V., Banerjee A., Hanna, R., Olken, B.A., Purnamasari, R. and Wai-Poi, M. (2016) Self-Targeting: Evidence from a Field Experiment in Indonesia. In Journal of Political Economy, 2016: pp 371-427. 
Fernandez, L. and Velarde, R. (2012). Who Benefits from Social Assistance in the Philippines? Evidence form the Latest National Household Surveys. Philippines Social Protection Note, No. 4. The World Bank: Manila.; Kidd, S. and Gelders, B. (2015) Child wellbeing and social security in Georgia: The case for moving to a more inclusive national social security system; HelpAge International's Global Age Watch Index 2015 and Social Pensions Database (2015); Silva-Leander, S., and F. Merttens (2016) Assessment of programme targeting. Oxford Policy Management: Oxford.;

World Bank (2012) Targeting Poor and Vulnerable Households in Indonesia. Jakarta.; World Bank (2009) Georgia: Poverty Assessment. Washington, DC.

333 United Nations Department on Economic and Social Affairs. (2018). Promoting Inclusion Through Social Protection. op. cit.

334 J. Gelbach and L. Pritchett. (2002). Is More for the Poor Less for the Poor? The Politics of Means-Tested Targeting https://ideas.repec.org/a/bpj/bejeap/vtopics.2y2002i1n6.html

335 B. Welham. (2014). Governance for Development. The World Bank. http://blogs.worldbank.org/governance/politics-service-delivery-0

336 S. Mehrotra. (2000). Integrating Economic and Social Policy: Good Practices from High-Achieving Countries. Innocenti Working Paper No. 80. Florence: UNICEF Innocenti Research Centre. Https://www.unicefirc.org/publications/pdf/iwp80.pdfhttps://www.unicef-irc.org/publications/pdf/iwp80.pdf

337 Data spanning 153 countries over a 14-year period from 1995 to 2008, after controlling for other factors. R. Moreno-Serra and P. Smith. (2011). The Effects of Health Coverage on Population Outcomes: A Country-Level Panel Data Analysis. Results for Development Institute Working Paper. https://www.r4d.org/resources/effects-health-coverage-population-outcomes/

338 Extreme poverty as 2011 PPP \$1.90-a-day poverty line. 'Severe financial difficulties' is used here to mean 'catastrophic health expenditure', which the WHO defines as household spending on health higher than $10 \%$ of household income. World Health Organization and World Bank. (2017). Tracking Universal Health Coverage: 2017 Global Monitoring Report. op. cit.

339 World Health Organization and World Bank. (2017). Tracking Universal Health Coverage: 2017 Global Monitoring Report. op. cit.

340 D. Cotlear and N. Rosemberg. (2018). Going Universal in Africa: How 46 African Countries Reformed User Fees and Implemented Health Care Priorities. World Bank Universal Health Coverage Study Series No. 26. http://documents.worldbank.org/curated/en/712041516179885313/Going-universal-inAfrica-how-46-African-countries-reformed-user-fees-and-implemented-health-carepriorities

341 Each year, 63 million people in India are pushed below the poverty line by paying out-of-pocket for healthcare. P. Berman, R. Ahuja and L. Bhandari. (2010). The Impoverishing Effect of Healthcare Payments in India: New Methodology and Findings. Economic and Political Weekly, 45(16): 65-71. https://www.epw.in/journal/2010/16/special-articles/impoverishing-effect-healthcarepayments-india-new-methodology-and

342 See Chapter 3 of L. Hamel, M. Norton, K. Pollitz, L. Levitt, G. Claxton and M. Brodie. (2016). The Burden of Medical Debt: Results from the Kaiser Family Foundation/New York Times Medical Bills Survey. The Henry J. Kaiser Family Foundation. https://www.kff.org/health-costs/report/the-burden-of-medical-debt-results-from-thekaiser-family-foundationnew-york-times-medical-bills-survey/

D.U. Himmelstein, D. Thorne, E. Warren and S. Woolhandler. (2009). Medical Bankruptcy in the United States, 2007: Results of a National Study. The American Journal of Medicine, 122(8): 741-6. https://www.amjmed.com/article/S0002-9343(09)00404$\underline{5 / f u l l t e x t}$

343 R. Yates. (2017). Hospitals That Act as Modern-day Debtor Prisons Deny Rights and Dignity. op. cit.

344 lbid.

345 Ibid. 
346 lbid.

347 World Bank. (2014). World Bank Group Support to Health Financing. http://ieg.worldbankgroup.org/sites/default/files/Data/reports/chapters/health finance evaluation $\mathrm{w}$ appendix updated.pdf

348 Ibid. and C. Averill and A. Marriott. (2013). Universal Health Coverage: Why health insurance schemes are leaving the poor behind. Oxfam. https://policypractice.oxfam.org.uk/publications/universal-health-coverage-why-health-insuranceschemes-are-leaving-the-poor-beh-302973

349 C. Averill and A. Marriott. (2013). Universal Health Coverage: Why health insurance schemes are leaving the poor behind. op. cit.

350 The success of health insurance schemes in terms of scale of coverage and equity depends on mandatory prepayment according to ability to contribute. A portion of the population will always require $100 \%$ government subsidy. Insurance payments can only be made mandatory by automatically deducting them via formal payroll systems. In countries with large-scale informal economies, it is not possible to deduct in this way from the majority of workers, so membership therefore becomes voluntary. Voluntary insurance schemes are characterized by adverse selection (people enrolling only when sick), inequality and inequity, and large-scale exclusion because people either cannot afford the required premium payment, or are unable or unwilling to pay for other reasons. The WHO in its 2010 World Health Report Health systems financing: the path to universal coverage is clear that voluntary insurance has never and will never work to achieve universal health coverage.

351 R.K. Alhassan, E. Nketiah-Amponsah, D.K. Arhinful. (2016). A Review of the National Health Insurance Scheme in Ghana: What Are the Sustainability Threats and Prospects? PLoS ONE 11(11): e0165151. doi:10.1371/journal. pone.0165151

352 C. Averill and A. Marriott. (2013). Universal Health Coverage: Why health insurance schemes are leaving the poor behind. op. cit.

World Bank. (2011). Ghana: Joint review of public expenditure and financial management. https://openknowledge.worldbank.org/handle/10986/2833

K. Saleh. (2013). The Health Sector in Ghana: A Comprehensive Assessment. World Bank. https://openknowledge.worldbank.org/handle/10986/12297

A. Kusi, U. Enemark, K.S. Hansen and F.A. Asante. (2015). Refusal to enrol in Ghana's National Health Insurance Scheme: is affordability the problem? International Journal for Equity in Health, 14(2): 1-14

https://equityhealthj.biomedcentral.com/articles/10.1186/s12939-014-0130-2

353 C. Averill and A. Marriott. (2013). Universal Health Coverage: Why health insurance schemes are leaving the poor behind. op. cit.

354 F. Huebler and E. Legault. (2017, June 2). The World's Families: Hidden Funders of Education. From UNESCO Institute for Statistics blog. https://sdg.uis.unesco.org/2017/06/02/the-worlds-families-hidden-funders-ofeducation/

355 UNESCO. (2015a). Education For All 2000-2015: Achievements and challenges. op. cit.

356 See speech given by Ghanaian President Akufo Ado, available here: https://www.youtube.com/watch?v= PNJjpw-Qb4

357 UN Development Programme. (2006). Beyond scarcity: Power, poverty and the global water crisis. Human Development Report 2006. http://hdr.undp.org/sites/default/files/reports/267/hdr06-complete.pdf Box 1.6. In practice, 25 litres been found to be not enough for the poorest households, and a steep escalation of costs after 25 litres means that poor families are often unduly penalized. There is strong case for the 25 -litre allowance being increased. For a discussion of this, see http://ourwatercommons.org/water-solutions/case-4-free-watersouth-africa

358 P. Espinoza Revollo et al. (2019). Public Good or Private Wealth? Methodology Note, op. cit.; A. Marriott. (2009). Blind Optimism. op. cit.; and B. Emmett. (2007). In the Public Interest Oxfam Campaign Report https://policy- 
practice.oxfam.org.uk/publications/in-the-public-interest-health-education-and-waterand-sanitation-for-all-112528

359 World Bank. (2018). World Development Report 2018. op. cit.

360 lbid.

361 P. Espinoza Revollo et al. (2019). Public Good or Private Wealth? Methodology Note, op. cit.

362 A. Marriott. (2009). Blind Optimism: Challenging the myths about private healthcare in poor countries. op. cit.

363 See for example, World Bank. (2004). World Development Report 2004. op. cit., and H. Patrinos et al. (2009). The Role of Public Private Partnerships in Education. World Bank. https://ppp.worldbank.org/public-private-partnership/library/role-and-impactpublic-private-partnerships-education and https://ppp.worldbank.org/public-privatepartnership/ppp-health

364 See, for example, B. N. Ghosh. (2008). Rich Doctors And Poor Patients: Market Failure And Health Care Systems In Developing Countries. Journal of Contemporary Asia, Volume 38. https://doi.org/10.1080/00472330701546525

365 Global Campaign for Education. (2016). Private Profit, Public Loss: why the push for low-fee private schools is throwing quality education off track. op. cit.

366 L.D. Ashley et al. (2014). The role and impact of private schools in developing countries. Department for International Development.

https://assets.publishing.service.gov.uk/government/uploads/system/uploads/attachm ent data/file/439702/private-schools-full-report.pdf

367 The study investigating schooling in villages in Uttar Pradesh, India, found low-cost private schools were unaffordable for children in the poorest two wealth quintiles. J. Harma. (2011). Low cost private schooling in India: Is it pro poor and equitable? International Journal of Educational Development 31 page 350-356 http://sites.miis.edu/comparativeeducation/files/2013/01/Low-cost-private-schoolingin-India.pdf

368 See, for example, H.A. Patrinos, F. Barrera-Osorio and J. Guaqueta. (2009). The Role and Impact of Public-Private Partnerships in Education. World Bank. https://ppp.worldbank.org/public-private-partnership/library/role-and-impact-publicprivate-partnerships-education

369 M. Afridi. (2018). Equity and Quality in an education public private partnership. op. cit. and A. Marriott. (2014). A Dangerous Diversion. op. cit.; and, for example, Eurodad. (2018). History RePPPeated. op. cit., House of Commons Treasury Committee (2011) Private Finance Initiative - Seventeenth Report of Session 201012, Published August 2012 by authority of the House of Commons London: The Stationary Office Limited; M. McKee, N. Edwards and R. Atun. (2006). Public Private Partnerships for Hospitals. Bulletin of the World Health Organization 2006: 84:890896.

370 T. C. Irwin (2018, October 16). How to Control the Fiscal Costs of Public-Private Partnerships. op. cit.

371 Eurodad (2018) History RePPPeated. op. cit., p.33

372 A. Marriott (2014). A Dangerous Diversion. op. cit.

373 This sum appears to exclude considerable disputed fees currently part of an arbitration process in Lesotho. Eurodad (2018) History RePPPeated. op. cit.

374 M. Afridi (2018). Equity and Quality in an education public private partnership. op. cit. 375 lbid.

376 It is an explicit goal of the WB-funded programme to 'expand outreach of the Punjab Education Fund (PEF) to 2.8 million out-of-school children'. World Bank. (2016). Third Punjab Education Sector Project. Project Appraisal Document.

377 M. Afridi. (2018). Equity and Quality in an education public private partnership. op. cit. 
378 See for example M. Lawson, S. Mazengera, F. Nkhoma-Mbawa and T.Noel. (2008). Malawi Essential Health Services: Country Case Study. Oxfam Research Report. https://www.oxfam.org/en/file/malawi-essential-services-casestudy-08119pdf

379 S. Mehrotra and R. Jolly (eds). (1997). Development with a Human FaceExperiences in Social Achievement and Economic Growth. Oxford: Clarendon Press.

Centro de Integridade Pública. (2011). O Distrito como Polo de Desenvolvimento: Um Olhar da Sociedade Civil

381 See a video about this work at: https://www.youtube.com/watch?v=5fKQchHYAIM\&feature=youtu.be

382 S.C. Sabi and M. Rieker. (2017). The role of civil society in health policy making in South Africa: a review of the strategies adopted by the Treatment Action Campaign. African Journal of AIDS Research, 16(1): 57-64. $\underline{\mathrm{h}}$ https://doi.org/10.2989/16085906.2017.1296874

383 S. Boseley. (2016, January 26). Big Pharma's worst nightmare. The Guardian. https://www.theguardian.com/society/2016/jan/26/big-pharmas-worst-nightmare

384 MenCare. (2018, April 4). Fathers in Rwanda use 40\% less violence against a partner nearly 2 years after MenCare program, reveals new study. https://mencare.org/2018/04/04/fathers-rwanda-use-less-violence-new-study/

385 D.K. Evans et al. (2015). Health-Care Worker Mortality And The Legacy Of The Ebola Epidemic. The Lancet Global Health, 3. https://doi.org/10.1016/S2214109X(15)00065-0

386 In 2013, the global shortage of healthcare workers was 17.4 million, including 2.6 million doctors and 9 million nurses and midwives. UNESCO. (2017). Global Education Monitoring Report 2017/8. op. cit.

387 K. Hodal. (2016). UN warns universal education goal will fail without 69 million new teachers. The Guardian. https://www.theguardian.com/globaldevelopment/2016/oct/05/un-universal-education-goal-fail-69-million-new-teachersunesco.

388 In Senegal, there are 0.07 doctors per 1,000 people, or 1 per 14,285 people. The World Bank Physicians (per 1,000

https://data.worldbank.org/indicator/SH.MED.PHYS.ZS WHO recommendation 1 doctor per 1000 people World Health Organization (WHO) (2018) Density of physicians (total number per 1000 population, latest available year) http://www.who.int/gho/health workforce/physicians density/en/

389 L. Addati et al. (2018). Care work and care jobs for the future of decent work. op. cit. 390 lbid.

391 Indicators for SDG 10: https://medium.com/sdgs-resources/sdg-10-indicatorsc52f0eae $5 \mathrm{~d} 4 \mathrm{e}$

392 Costings for meeting all of the 17 SDGs are $\$ 360 \mathrm{bn}$ for low-income countries, and \$944bn for lower-middle-income countries. G. Schmidt-Traub. (2015). Investment Needs to Achieve the Sustainable Development Goals. Sustainable Development Solutions Network. http://unsdsn.org/wp-content/uploads/2015/09/151112-SDGFinancing-Needs.pdf

393 Figures for decline in US Tax rates taken from T. Piketty. (2014). Capital in the 21st Century. op. cit.

394 Calculations for 123 developing countries taken form the Commitment to Reducing Inequality index database for 2018. M. Lawson and M. Martin. (2018). Commitment to Reducing Inequality index 2018. op. cit.

395 E. Berkhout. (2016). Tax Battles: The dangerous global race to the bottom on corporate tax. Oxfam. https://policy-practice.oxfam.org.uk/publications/tax-battles-thedangerous-global-race-to-the-bottom-on-corporate-tax-620159 and G. Zucman. (2015). The Hidden Wealth of Nations. op. cit.

396 R. Toplensky. (2018, March 11). Multinationals pay lower taxes than a decade ago. Financial Times. https://www.ft.com/content/2b356956-17fc-11e8-9376- 
4a6390addb44. The FT examined the tax rates paid by the world's 10 biggest public companies by market capitalization in each of 9 sectors. The tax rates reported by the 10 multinationals with the largest offshore cash piles were also examined.

397 A. Shorrocks, J. Davies and R. Lluberas. (2018). Global Wealth Report. op. cit.

398 IMF Fiscal Monitor. (2013). Taxing Times.

https://www.imf.org/en/Publications/FM/Issues/2016/12/31/Taxing-Times and M. Lawson and M. Martin. (2018). Commitment to Reducing Inequality index 2018. op. cit.

399 For a fuller analysis of the extent to which countries are living up to their tax potential, please see Oxfam and DFI's Commitment to Reducing Inequality index 2018.

400 K. Scheve and D. Stasavage (2016) Taxing the Rich. op. cit.

401 Tax Foundation Data. https://github.com/TaxFoundation/data/blob/master/OECDcorporate-income-tax-rates/OECD corp income tax rates 1981-2015.csv\#L1

402 K. Alavuotunki et al. (2018). The Effects of the Value-Added Tax on Revenue and Inequality. The Journal of Development Studies, pp.1-19. https://doi.org/10.1080/00220388.2017.1400015

403 Source: Oxfam calculation based on data from: N. Lustig. (2017). The Impact of the Tax System and Social Spending on Income Distribution and Poverty in Latin America. An application of the methodological framework by the Commitment to Equality Project (CEQ); for details see R. Cañete-Alonso (2018) Captured Democracy: Government for the Few. Oxfam and CLACSO. https://d1tn3vi7xz9fdh.cloudfront.net/s3fspublic/file attachments/captured democracy executive summary.pdf

404 For a discussion of the way that the progressivity of corporate tax is being undermined see E. Berkhout. (2016). Tax Battles: The dangerous global race to the bottom on corporate tax. op. cit.

405 For a discussion of the extent to which the richest are dodging tax please see $\mathrm{G}$. Zucman. (2015). The Hidden Wealth of Nations. op. cit. For a discussion of the low levels of collection of personal income tax, see Lawson and M. Martin. (2018). Commitment to Reducing Inequality index 2018. op. cit.

406 OECD Stat. Revenue Statistics - OECD countries: Comparative tables. https://stats.oecd.org/viewhtml.aspx?datasetcode=REV\&lang=en

407 World Bank Group. (2016). Poverty and Shared Prosperity 2016: Taking on Inequality. https://doi.org/10.1596/978-1-4648-0958-3

408 Taxes are knocking off only about 2.5 percentage points of the income Gin coefficient, which has remained stable despite an increase in inequality, according to a study of fifteen rich countries between 1985 and 2013. K. Caminada, J. Wang, K. Goudswaard and C. Wang. (2017). Income Inequality and Fiscal Redistribution in 47 LIS-countries, 1967-2014. Luxembourg Income Study (LIS) Working Paper Series No.724. http://www.lisdatacenter.org/wps/liswps/724.pdf

409 C. Isidore. (2013). Buffett says he's still paying lower tax rate than his secretary. op. cit.

410 Sources: Brazil INESC. 2015. 'Mineração e (in)justiça tributária no Brasil'. Nota Técnica 184. Available at: http://www.inesc.org.br/noticias/biblioteca/publicacoes/notas-tecnicas/nts-2015/notatecnica-184-mineracao-e-in-justica-tributaria-no-brasil/view. And UK Office for National Statistics (2018) Effects of taxes and benefits on household income https://www.ons.gov.uk/peoplepopulationandcommunity/personalandhouseholdfinanc es/incomeandwealth/datasets/theeffectsoftaxesandbenefitsonhouseholdincomefinanci alyearending2014 Table 14: Average incomes, taxes and benefits by decile groups of ALL households (ranked by UNADJUSTED disposable income), 2016/17.

411 D. Pimentel et al. (2018). Reward Work, Not Wealth. op. cit.

412 A. Berg. (2018). Should we fear the Robot Revolution? IMF Working Paper WP/18/116 file:///C:/Users/mlawson/Downloads/wp18116.pdf

413 D. Pimentel et al. (2018). Reward Work, Not Wealth. op. cit. 
414 IMF. (2013). Fiscal Monitor, Taxing Times. op. cit.

415 World Bank. (2016). Taking on Inequality, Poverty and Shared Prosperity 2016.

Retrieved 7 November 2017, from https://doi.org/10.1596/978-1-4648-0958-3

416 P. Toynbee. (2018, September 18). The African youth boom: what's worrying Bill Gates. The Guardian. https://www.theguardian.com/globaldevelopment/2018/sep/18/the-african-youth-boom-whats-worrying-bill-gates

417 The Economist. (2018, August 9). Overhaul tax for the 21st century. https://www.economist.com/leaders/2018/08/09/overhaul-tax-for-the-21st-century

418 R. Fuentes-Nieva and N. Galasso. (2014). Working for the Few: Political capture and economic inequality. Oxfam. https://policy-practice.oxfam.org.uk/publications/workingfor-the-few-political-capture-and-economic-inequality-311312

419 R. Cañete-Alonso (2018) Captured Democracy: Government for the Few. Oxfam and CLACSO, op. cit.

420 World Bank Group. (2016). Poverty and Shared Prosperity 2016. op. cit.

421 T. Piketty. (2014). Capital in the Twenty-First Century. A. Goldhammer, transl. Cambridge Massachusetts: The Belknap Press of Harvard University Press. https://doi.org/10.4159/9780674369542

422 IMF. (2013). Taxing Times. https://www.imf.org/en/Publications/FM/Issues/2016/12/31/Taxing-Times

423Oxfam in Bangladesh and SUPRO. Fair Tax Monitor - Bangladesh (2018). Publication forthcoming. Pages 14 and 15.

424 A typical individual owning INR1 million $(\$ 14,000)$ paid INR1,832 $(\$ 25)$ in tax instead of INR14,560 (\$204). Oxfam India. (March 2018). On some implications of wealth taxes and inequality. Policy brief 29.

https://www.oxfamindia.org/sites/default/files/PB On\%20Some $\% 20$ Implications $\% 20$ of \%20Wealth\%20Taxes\%20on\%20Inequality\%20in\%20India.pdf

425 Ibid.

426 P. Espinoza Revollo et al. (2019). Public Good or Private Wealth? Methodology Note, op. cit.

427 About Move Humanity Campaign: https://movehumanity.org/

428 J.D. Ostry, A. Berg and C.G. Tsangarides. (2014). Redistribution, Inequality, and Growth. op. cit.

Another IMF study finds that the inflection point at which more redistribution starts to harm economic growth is a Gini coefficient under 0.27 ; only a handful of European countries achieve such a low level of inequality at this point. F. Grigoli and A. Robles. (2017). Inequality Overhang. IMF Working Paper No.17/76. https://www.imf.org/en/Publications/WP/Issues/2017/03/28/Inequality-Overhang$\underline{44774}$

On the room for countries to tax the rich more, see IMF. (2013) Fiscal Monitor: Taxing Times op. cit. and IMF. (2017). Fiscal Monitor: Tackling Inequality. op. cit.

429 Piketty argues that because high pay largely reflects windfall income, such as the bargaining power that executives enjoy to negotiate huge bonuses (rather than additional effort), a high top tax rate does not reduce effort much. T. Piketty, E. Saez and S. Stantcheva. (2011). Optimal Taxation of Top Labor Income: A Tale of Three Elasticities. NBER Working Paper Series No.17616. http://www.nber.org/papers/w17616

430 Oxfam and Development Finance International. (2018). The Commitment to Reducing Inequality Index 2018. op. cit.

431 B. Brys et al. (2016). Tax Design for Inclusive Economic Growth. OECD.

432 Ibid. and also T. Piketty (2014) Capital in the 21st Century. op. cit. 
433 See, for example, C. Dubay. (2010). The Case Against the Death Tax, op. cit; and Kit Bond Quotes. https://www.brainyquote.com/quotes/kit bond 348278, accessed December 6, 2018.

434 The Economist. (2017). Taxing Inheritances is Falling out of Favour https://www.economist.com/briefing/2017/11/23/taxing-inheritances-is-falling-out-offavour [paywall]

435 R. Cañete-Alonso (2018) Captured Democracy: Government for the Few. Oxfam and CLACSO, op. cit.

436 Ibid. and K. Scheve And D Stasavage (2016) Taxing the Rich. Russell Sage Foundation.

437 G. Zucman. (2015). The Hidden Wealth of Nations, op cit. See the methodology note for Oxfam's 2018 Davos report for an explanation of workings: D. Hardoon et al. (2018). Reward Work, Not Wealth. Methodology Note, op cit.

438 G. Zucman. (2015). The Hidden Wealth of Nations. op. cit.

See also: D. Hardoon et al. (2018). Reward Work, Not Wealth: Methodology note; A Alstadsæter et al. (2017). Tax Evasion and Inequality. op. cit.

439 G. Zucman (2015). The Hidden Wealth of Nations. op. cit.

440 United Nations Conference on Trade and Development (UNCTAD). (2015). World Investment Report 2015: Reforming international investment governance. http://unctad.org/en/PublicationsLibrary/wir2015 en.pdf.

Other estimates of the cost of corporate tax dodging for developing countries range from \$47bn to \$200bn, see: E. Crivelli, R.A. De Mooij and M. Keen. (2015). Base Erosion, Profit Shifting and Developing Countries. op. cit.; T.R. Tørsløv, L.S. Wier and G. Zucman. (2018). The Missing Profits of Nations. op. cit. See in particular Appendix C. $4 \mathrm{~d}$ of the latter, available here: http://gabrielzucman.eu/files/TWZ2018Appendix.pdf.

441 C. Godfrey. (2014). Business Among Friends: Why corporate tax dodgers are not yet losing sleep over global tax reform. Oxfam. http://policypractice.oxfam.org.uk/publications/business-among-friends-why-corporate-taxdodgers-are-not-yet-losing-sleep-over-316405

442 E. Berkhout. (2016). Tax Battles: The dangerous global race to the bottom on corporate tax. op. cit.

443 lbid.

444 World Bank. (n.d.) Enterprise Surveys: Gender. http://www.enterprisesurveys.org/Data/ExploreTopics/gender

445 K.A. Lahey. (2018). Gender, Taxation and Equality in Developing Countries. op. cit.

446 M. Stephenson. (2018). A Guide To Gender-Responsive Budgeting. Oxfam. https://doi.org/10.21201/2017.1848

447 J.G. Stotsky. (2016). Gender Budgeting: Fiscal Context and Current Outcomes. IMF Working Paper 16/149.

https://www.imf.org/en/Publications/WP/lssues/2016/12/31/Gender-Budgeting-FiscalContext-and-Current-Outcomes-44132 and KPMG. (2018). South Africa: VAT rate increases to 15\%, effective April 2018.

https://home.kpmg.com/xx/en/home/insights/2018/02/tnf-south-africa-vat-rateincrease-to-15-percent-effective-april-2018.html

448 N. Andersen. (2018). Sanitary products, nappies and more: Treasury announces new VAT zero-rated items. The South African. https://www.thesouthafrican.com/sanitaryproducts-nappies-treasury-vat-zero-rated/.

449 M.K. Justensen and C. Bjornskov. (2014). Exploiting the Poor: Bureaucratic corruption and poverty in Africa. Afrobarometer Working Paper No. 139. https://www.files.ethz.ch/isn/151822/afropaperno139.pdf

450 B.J. Fried, P. Lagunes and A. Venkataramani. (2010). Corruption and Inequality at the Crossroad: Correlation between corruption and inequality: A Multi-Method Study 
of Bribery and Discrimination in Latin America. Latin American Research Review, 45(1): 76-97. https://doi.org/10.1353/lar.0.0107

451 Empirical studies have consistently demonstrated that the poorest people pay the highest percentage of their income in bribes. For example, in Paraguay, poor people pay $12.6 \%$ of their income in bribes while high-income households pay $6.4 \%$. World Bank. (2018c). Combating Corruption.

http://www.worldbank.org/en/topic/governance/brief/anti-corruption

452 J. Rheinby and M. Chene. (2016). Gender and Corruption: Topic Guide. Transparency International. https://www.transparency.org/files/content/corruptionqas/Topic guide gender corrupt ion Final 2016.pdf

453 N. Hossain, C. Nyamu Musembi and J. Hughes. (2010). Corruption, Accountability and Gender: Understanding the Connections. UNIFEM and UNDP. http://www.undp.org/content/dam/aplaws/publication/en/publications/womensempowerment/corruption-accountability-and-gender-understanding-theconnection/Corruption-accountability-and-gender.pdf

454 The Economist. (2018). London's financial flows are polluted by laundered money. https://www.economist.com/leaders/2018/10/11/londons-financial-flows-are-pollutedby-laundered-money

455 Financial Action Task Force - Egmont Group. (2018). Concealment of Beneficial Ownership. http://www.fatf-

gafi.org/publications/methodsandtrends/documents/concealment-beneficialownership.html

456 B. Torgler et al. (2008). Causes and Consequences of Tax Morale: An Empirical Investigation. Economic Analysis \& Policy, Volume 38, Number 2, September 2008, pp. 313-339. https://doi.org/10.1016/S0313-5926(08)50023-3

457 R. Jovine and R. Cañete. (2017). Se Buscan: Recursos para Garantizar Derechos. Oxfam. https://www.oxfam.org/es/republica-dominicana/republica-dominicanaeliminar-el-malgasto-publico-para-garantizar-derechos

458 M. Manuel, H. Desai, E. Samman and M. Evans. (2018). Financing the end of extreme poverty. Overseas Development Institute (ODI). https://www.odi.org/sites/odi.org.uk/files/resource-documents/12411.pdf p33.

459 G. Gertz and H. Kharas. (2018). Leave No Country Behind: Ending poverty in the toughest places. Global Economy \& Development Working Paper 110. Brookings Institution. https://www.brookings.edu/wpcontent/uploads/2018/02/leave no country behind working paper.pdf

460 G-M. Lange, Q. Wodon and K. Carey (eds). (2018). The Changing Wealth of Nations 2018: Building a Sustainable Future. World Bank. https://openknowledge.worldbank.org/handle/10986/29001 p.46.

461 W. Rodney. (1973). How Europe Underdeveloped Africa. Bogle-L'Ouverture Publications http://abahlali.org/files/3295358-walter-rodney.pdf

462 Eurodad. (2013). Giving with one hand and taking with the other - Europe's role in tax-related capital flight from developing countries. https://eurodad.org/takingwithonehand2013

463 G. Adams and D. Rosche. (2016). Accountability and Ownership: The role of aid in a post-2015 world. Oxfam International. https://policypractice.oxfam.org.uk/publications/accountability-and-ownership-the-role-of-aid-in-apost-2015-world-619839

464 International Development Strategy for the Second United Nations Development Decade, UN General Assembly Resolution 2626 (XXV), 24 October 1970, paragraph 43. Note that OECD DAC members generally accepted the $0.7 \%$ target for ODA, at least as a long-term objective, with some notable exceptions: Switzerland - not a member of the UN until 2002 - did not adopt the target, and the US stated that it did not subscribe to specific targets or timetables, although it 'supported the more general aims of the Resolution'.

465 These five are Sweden, Norway, the UK, Luxembourg and Denmark. OECD. (2017). Development aid stable in 2017 with more sent to poorest countries. 
http://www.oecd.org/newsroom/development-aid-stable-in-2017-with-more-sent-topoorest-countries.htm

466 Development Initiatives. (2018). Investments to End Poverty 2018.

http://devinit.org/post/investments-to-end-poverty-2018/, p104

467 M. Manuel et al. (2018). Financing the end of extreme poverty. op. cit. p29.

468 UNESCO. (2015a). Education For All 2000-2015: Achievements and challenges. op. cit. p.21

469 T. de Chaisemartin. (2017). How GPE Supports Teaching and Learning. Global Partnership for Education Policy Brief.

https://www.globalpartnership.org/content/policy-brief-how-gpe-supports-teachingand-learning

470 UNESCO. (2015b). Gender and EFA 2000-2015: Achievements and Challenges, Gender Summary. http://unesdoc.unesco.org/images/0023/002348/234809E.pdf

471 Development Initiatives. (2018). Investments to End Poverty 2018. op. cit. p47.

472 UN InterAgency Task Force (IATF) on financing social protection floors (2017), led by the ILO.

473 Oxfam. (2018a). Doubling down on 'DRM': Are We Making the Right Bets? https://www.oxfamamerica.org/static/media/files/DOUBLING DOWN ON DRM 2018 LVC7aXc.pdf

474 G. Adams and D. Rosche. (2016). Accountability and Ownership: The role of aid in a post-2015 world. op cit.

475 OECD. (2018). Aid to gender equality and women's empowerment: An overview. http://www.oecd.org/dac/gender-development/Aid-to-gender-overview-2018.pdf

476 T. Jones. (2015). The new debt trap: How the response to the last global financial crisis has laid the ground for the next. https://jubileedebt.org.uk/wpcontent/uploads/2015/07/The-new-debt-trap 07.15.pdf

477 Government of Kenya. Estimates of Recurrent Expenditure of the Government of Kenya for the year ending 30 June 2019.

http://www.treasury.go.ke/component/jdownloads/send/198-2018-2019/1055recurrent-budget-volume-i.html

478 The Economist. (2018, September 15). Zambia's looming debt crisis is a warning for the rest of Africa. https://www.economist.com/leaders/2018/09/15/zambias-loomingdebt-crisis-is-a-warning-for-the-rest-of-africa

479 Jubilee Debt Campaign. (2018). Africa's growing debt crisis: Who is the debt owed to? https://jubileedebt.org.uk/wp/wp-content/uploads/2018/10/Who-is-Africa-debtowed-to 10.18.pdf

480 IMF. (2018, August 1). List of LIC DSAs for PRGT-Eligible Countries. https://www.imf.org/external/Pubs/ft/dsa/DSAlist.pdf

481 The Economist. (2018, September 15). Zambia's looming debt crisis is a warning for the rest of Africa, op cit.

482 P. Fabricius. (2018, September 20). Indebted Africa returns to the International Monetary Fund. Institute for Security Studies. https://issafrica.org/iss-today/indebtedafrica-returns-to-the-international-monetary-fund. This is not just an African issue, however, with countries like Pakistan also returning to the IMF in the face of serious debt distress.

483 C. Mariotti et al. (2017). Great expectations: is the IMF turning words into action on inequality? op. cit.

484 I. Ortiz and M. Cummins. (2013) Austerity Measures in Developing Countries. op. cit. 485 See for example: Oxfam. (1999). IMF: Wrong Diagnosis, Wrong Medicine.

Structural Adjustment Participatory Review International Network (SAPRIN). (2004). The Policy Roots of Economic Crisis and Poverty: A Multi-Country Participatory Assessment of Structural Adjustment. http://www.saprin.org/SAPRI Findings.pdf 
L. Beneria and S. Feldman. (1992) Unequal Burden: Economic Crises, Persistent Poverty and Women's Work. Boulder: Westview Press.

486 L. Ndiumana and J. Boyce. (2002). Public Debts and Private Assets: Explaining Capital Flight from Sub-Saharan African Countries. Political Economy Research Institute (PERI) Working Paper No. 32. University of Massachusetts Amherst. https://papers.ssrn.com/sol3/papers.cfm?abstract id=333765

487 M. Vervynckt and M. Romero. (2017). Public-Private Partnerships: Defusing the ticking time bomb. Eurodad. https://eurodad.org/files/pdf/1546817-public-privatepartnerships-defusing-the-ticking-time-bomb-.pdf

488 According to Evans (2018) this is based on three things: increased government revenue (invested in labour, skills through improved education, and redistribution); democratization; and social movements. These social movements enabled publics to look to their neighbours and see organized, vocal groups changing governments and holding them to account. This facilitated a regional domino effect, where people allowed themselves to believe there were alternative 'norms' to the political status quo and emboldened them to make change in their own countries. A. Evans (2018) Politicising Inequality: The Power of Ideas'. World Development, 110. https://www.researchgate.net/publication/321807746 Politicising Inequality The Po wer of Ideas

489 B. Mwangi. (2015, January 20). \#OccupyPlayGround: police used teargas on our children, but for now we celebrate the win. The Guardian. https://www.theguardian.com/global-development/povertymatters/2015/jan/20/occupyplayground-police-used-teargas-on-our-children-but-fornow-we-celebrate-the-win

490 U. Goni. (2016). Argentina's women joined across South America in marches against violence. The Guardian. https://www.theguardian.com/world/2016/oct/20/argentinawomen-south-america-marches-violence-ni-una-menos

491 S. James. (2018, March 8). Decades after Iceland's 'day off', our women's strike is stronger than ever. The Guardian. https://www.theguardian.com/commentisfree/2018/mar/08/iceland-global-womensstrike-protest

492 See www.figthinequality.org 


\section{OXFAM}

Oxfam is an international confederation of 19 organizations networked together in more than 90 countries, as part of a global movement for change, to build a future free from the injustice of poverty. Please write to any of the agencies for further information, or visit www.oxfam.org

Oxfam America (www.oxfamamerica.org)

Oxfam Australia (www.oxfam.org.au)

Oxfam-in-Belgium (www.oxfamsol.be)

Oxfam Brasil (www.oxfam.org.br)

Oxfam Canada (www.oxfam.ca)

Oxfam France (www.oxfamfrance.org)

Oxfam Germany (www.oxfam.de)

Oxfam GB (www.oxfam.org.uk)

Oxfam Hong Kong (www.oxfam.org.hk)

Oxfam IBIS (Denmark) (www.oxfamibis.dk)

Observer:

KEDV (Oxfam Turkey)
Oxfam India (www.oxfamindia.org)

Oxfam Intermón (Spain) (www.oxfamintermon.org)

Oxfam Ireland (www.oxfamireland.org)

Oxfam Italy (www.oxfamitalia.org)

Oxfam Mexico (www.oxfammexico.org)

Oxfam New Zealand (www.oxfam.org.nz)

Oxfam Novib (Netherlands) (www.oxfamnovib.nl)

Oxfam Québec (www.oxfam.qc.ca)

Oxfam South Africa (www.oxfam.org.za) 